\title{
Papua New Guinea: Selected Issues and Statistical Appendix
}

This Selected Issues paper and Statistical Appendix for Papua New Guinea was prepared by a staff team of the International Monetary Fund as background documentation for the periodic consultation with the member country. It is based on the information available at the time it was completed on January 31,2008 . The views expressed in this document are those of the staff team and do not necessarily reflect the views of the government of Papua New Guinea or the Executive Board of the IMF.

The policy of publication of staff reports and other documents by the IMF allows for the deletion of market-sensitive information.

To assist the IMF in evaluating the publication policy, reader comments are invited and may be sent by e-mail to publicationpolicy@imf.org.

Copies of this report are available to the public from

International Monetary Fund $\bullet$ Publication Services

700 19th Street, N.W. • Washington, D.C. 20431

Telephone: (202) 6237430 • Telefax: (202) 6237201

E-mail: publications@imf.org • Internet: http://www.imf.org

Price: $\$ 18.00$ a copy

\section{International Monetary Fund Washington, D.C.}





\section{INTERNATIONAL MONETARY FUND}

\section{PAPUA NEW GUINEA}

\section{Selected Issues and Statistical Appendix}

Prepared by Qaizar Hussain, Ebrima Faal, Theo Thomas, Aiko Mineshima, Agnes Isnawangsih (all APD); and Qi He (STA)

Approved by the Asia and Pacific Department

January 31, 2008

Contents

Page

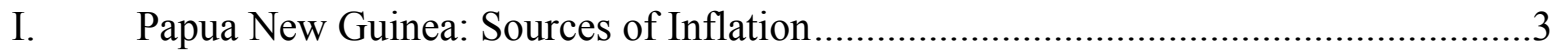

II. The Monetary Transmission Mechanism in Papua New Guinea............................13

III. Papua New Guinea: Export Performance and Competitiveness.............................30

IV. Financial Sector Developments in Papua New Guinea ........................................49

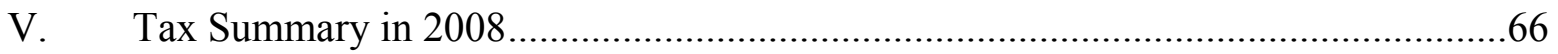

Statistical Tables

1. Gross Domestic Product by Sector at Current Market Prices, 2002-06 ...................76

2. Gross Domestic Product by Sector at 1998 Constant Prices, 2002-06 ...................77

3. Production of Major Commodities, 2002-05 ......................................................78

4. Employment by Sector, 2003-June 2007 ….....................................................79

5. Consumer Price Index by Expenditure Group, 2002-June 2007.............................80

6a. Central Government Budget, 2002-07 (in millions of kina) ..................................81

6b. Central Government Budget, 2002-07 (in percent of GDP) .................................82

7. Central Government Revenue and Grants, 2002-07 ...........................................83

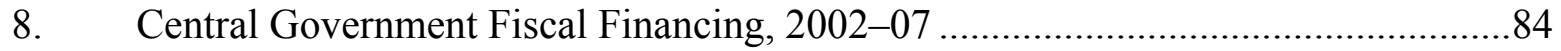

9. Central Government Domestic Debt, 2003-September 2007................................85

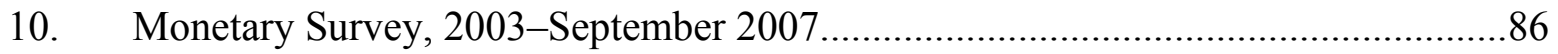

11. Balance Sheet of the Central Bank, 2003-September 2007 .................................87

12. Consolidated Balance Sheet of Other Depository Corporations, 2003-September 2007 .88

13. Commercial Bank Loans by Sector, 2003-September 2007 ................................89

14. Reserve Requirements, March 1997-September 2007 .......................................90 


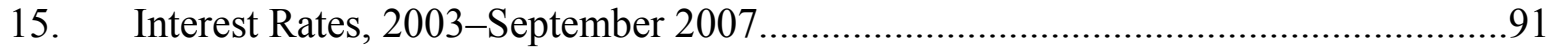

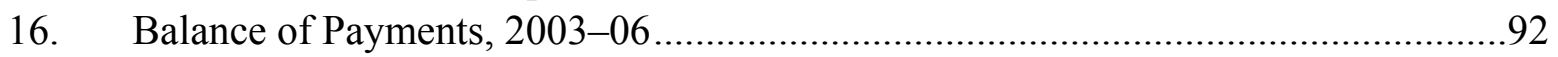

17. Exports of Major Commodities, 2003-06 …..........................................................93

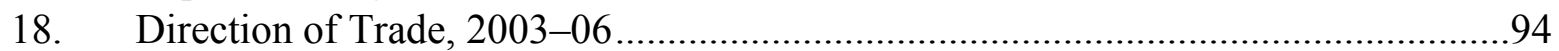

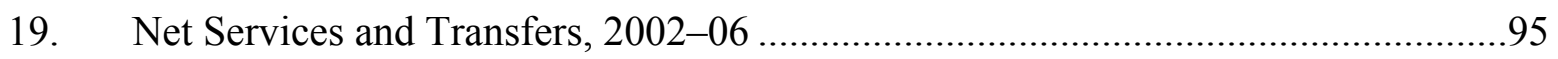

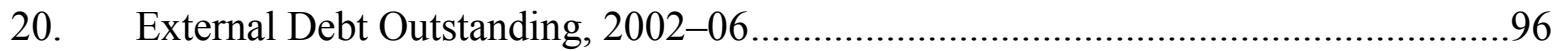

21. Public External Debt Service, 2002-06 .........................................................97

22. Medium-Term Development Strategy - Performance Management Framework,

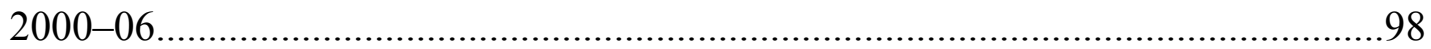




\section{Sources of Inflation in Papua New Guinea ${ }^{1}$}

\section{A. Introduction}

1. Since 2004, Papua New Guinea's inflation has been low, compared to its historical level and peer countries' inflation, in spite of rapid broad money growth and increased government expenditure. This chapter examines the possible explanations for this puzzle by analyzing the sources of inflation in Papua New Guinea. The results from the empirical analysis indicate that kina exchange rate movements are the most important determinant of inflation in Papua New Guinea, and correspondingly, appreciation of the kina has contributed to the low inflation. Changes in broad money growth, government expenditure, and oil prices also have had an impact on inflation. In particular, the findings suggest that recent rapid broad money growth, increased government expenditure, and higher oil prices could increase inflationary pressure in the near future. Cross-country analysis suggests that similar relationships between inflation and the above economic variables hold in Papua New Guinea's peer countries as well. This analysis accordingly indicates that low inflation in Papua New Guinea compared to its peer countries was mainly caused by kina appreciation, in addition to relatively low, though increasing, government expenditure growth.

2. The structure of the remainder of this chapter is as follows: Section B reviews recent developments in inflation in Papua New Guinea and the economic environments surrounding it; Section $\mathrm{C}$ presents an empirical analysis of the relationship between inflation and different macroeconomic variables; Section D considers cross-county inflation analyses; and Section E presents the conclusions.

\section{B. Inflation and the Economic Environment}

\section{Papua New Guinea's inflation declined} sharply in 2003 and has remained in low single digits since $2004 .^{2}$

\section{Inflation historically has had a strong} negative correlation with foreign exchange rate movements. The country experienced high inflation in line with depreciation of the kina exchange rate in 1995-96 (following the change in the foreign exchange regime from a pegged

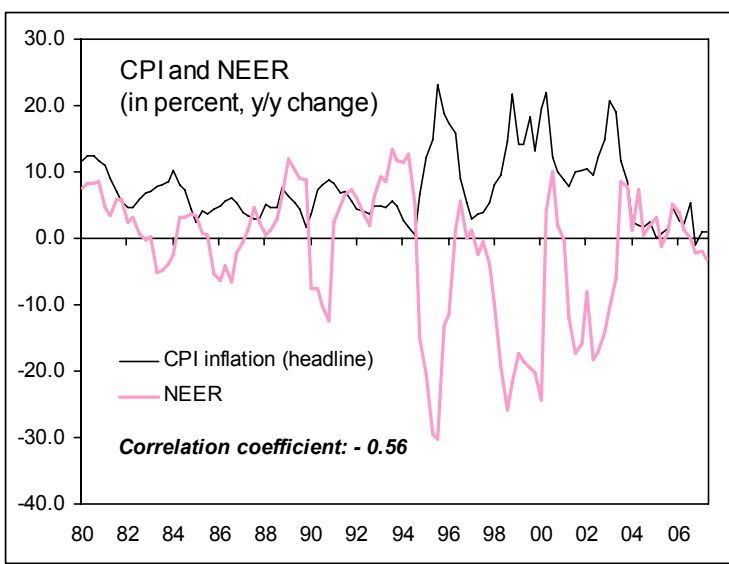

\footnotetext{
${ }^{1}$ Prepared by Aiko Mineshima. This chapter is based on a presentation delivered at the Bank of Papua New Guinea in Port Moresby in November 2007 and benefits from comments received at that time.

2 The quality of CPI data for Papua New Guinea is poor: for example, the weights are outdated (based on a 1975-76 Household Income and Expenditure Survey), and prices on dwelling rentals, which compose about 3.9 percent of the headline CPI basket, have not been collected since 1991 and are therefore held constant.
} 
regime to an independent float), 1998-2000, and 2001-03. Since 2004, with the roughly unchanged or somewhat appreciated kina exchange rate, inflation has been low.

5. Movements in headline inflation are mainly explained by tradable goods, which account for 77 percent of the CPI basket. ${ }^{3}$ Therefore, despite relatively large price increases in nontradable goods from 2006, headline inflation has been subdued. ${ }^{4}$ Given that most tradable goods are imported, changes in the exchange rate and prices abroad have an impact on PNG's domestic goods prices. Further disaggregation of headline CPI indicates that for tradable goods, food has been a key source of underlying inflationary pressure. Prices of "transport/ communication" and "rent, council charges, and fuel/power" have increased since 2006, mainly pushed by high oil prices, but overall these were offset by lower prices of "drinks, tobacco, and betel nut" and "household equipment/operations," resulting in lower headline inflation.
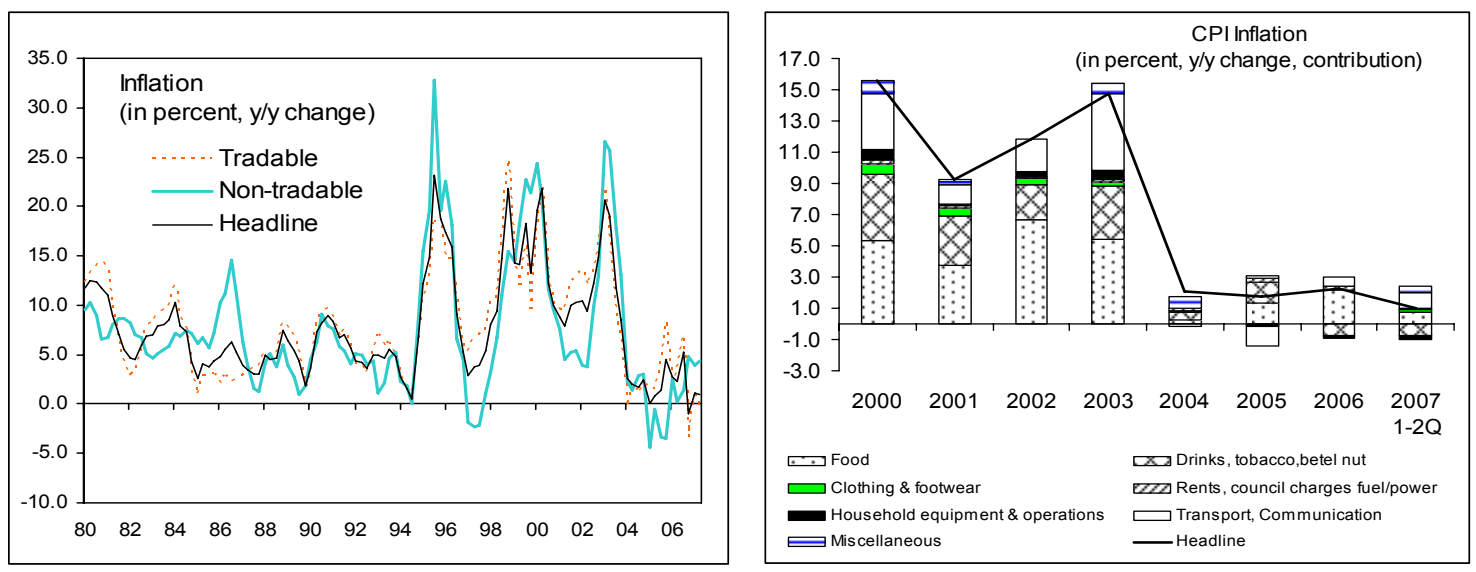

6. Papua New Guinea's monetary conditions have remained roughly unchanged since mid-2004. The policy rate of the Bank of Papua New Guinea (BPNG), the Kina Facility Rate (KFR), decreased from mid-2003 to September 2005 following a year of tightening in 2002. Since September 2005, the KFR has been unchanged at 6 percent, a historically low level, while several of Papua New Guinea's partner countries began raising policy rates in 2002-04. The staff's nominal monetary condition index (MCI) suggests that monetary conditions in Papua New Guinea have been roughly unchanged at the most relaxed level in the last 10 years from 2003 through $2006 .{ }^{5}$ However, in real terms, monetary conditions tightened

\footnotetext{
${ }^{3}$ Tradable goods include: food; drinks, tobacco, and betel nut; clothing and footwear; household equipment; and motor vehicles.

${ }^{4}$ Nontradable goods include: rents, council charges, and fuel/power; transport and communication; and miscellaneous.

${ }^{5}$ The monetary condition index (MCI) is a weighted average of changes in the effective exchange rate and interest rates relative to a base period (in this case, end-1996). Reflecting the relative influence on monetary conditions, the weights for Papua New Guinea are 75 percent for the NEER and 25 percent for the interest rate. As Papua New Guinea is a small, open economy with a shallow financial market, the impact of exchange rate movements on monetary conditions is more significant than in more developed economies.
} 
in 2003 in line with the REER appreciation, resulting from the spike in inflation, and has roughly unchanged since then.
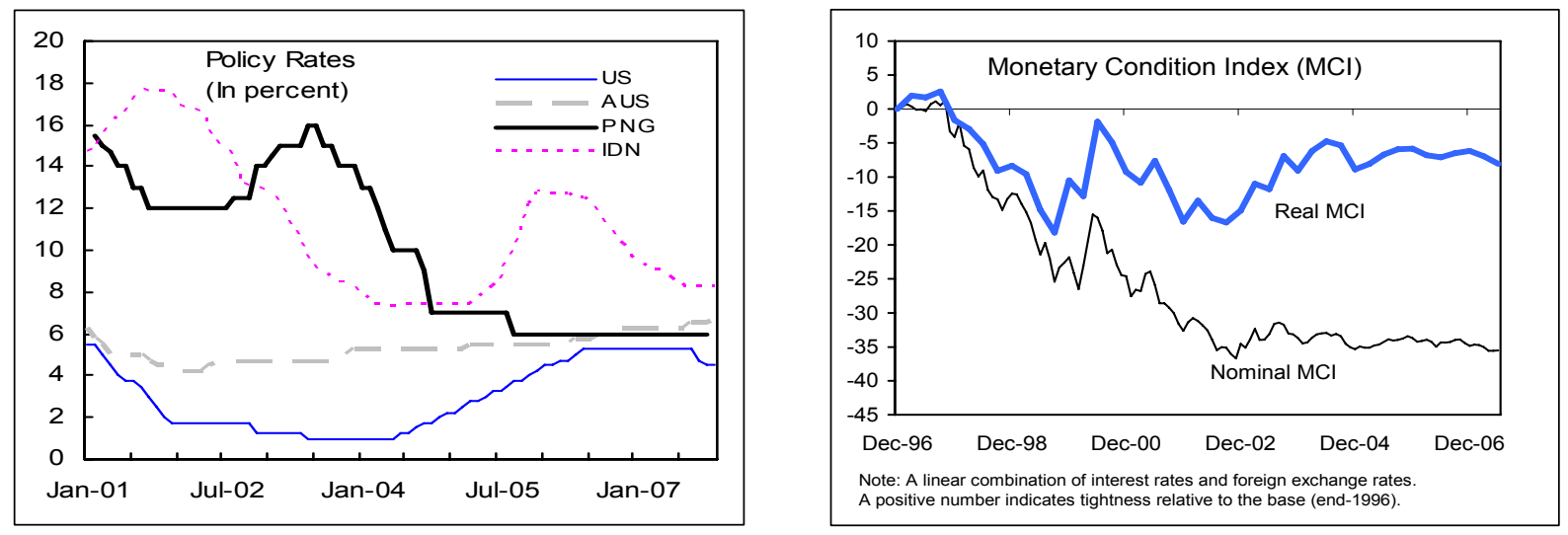

7. Monetary aggregate growth began accelerating in 2004, as high prices for Papua New Guinea's key commodity exports increased net foreign asset inflows. The BPNG intervened in the foreign exchange market to smooth exchange rate movements and avoid excessive appreciation of the kina against the U.S. dollar. It sterilized excess liquidity mainly by issuing central bank bills to maintain reserve money within its target growth rate. Net domestic asset growth began accelerating in 2005, driven by the recovery in private credit, which was in turn fueled by sound economic conditions, low interest rates, and improved financial intermediation. However, since 2006, net domestic asset growth has been near zero, as continued private credit growth has been offset by rising government deposits at the BPNG.
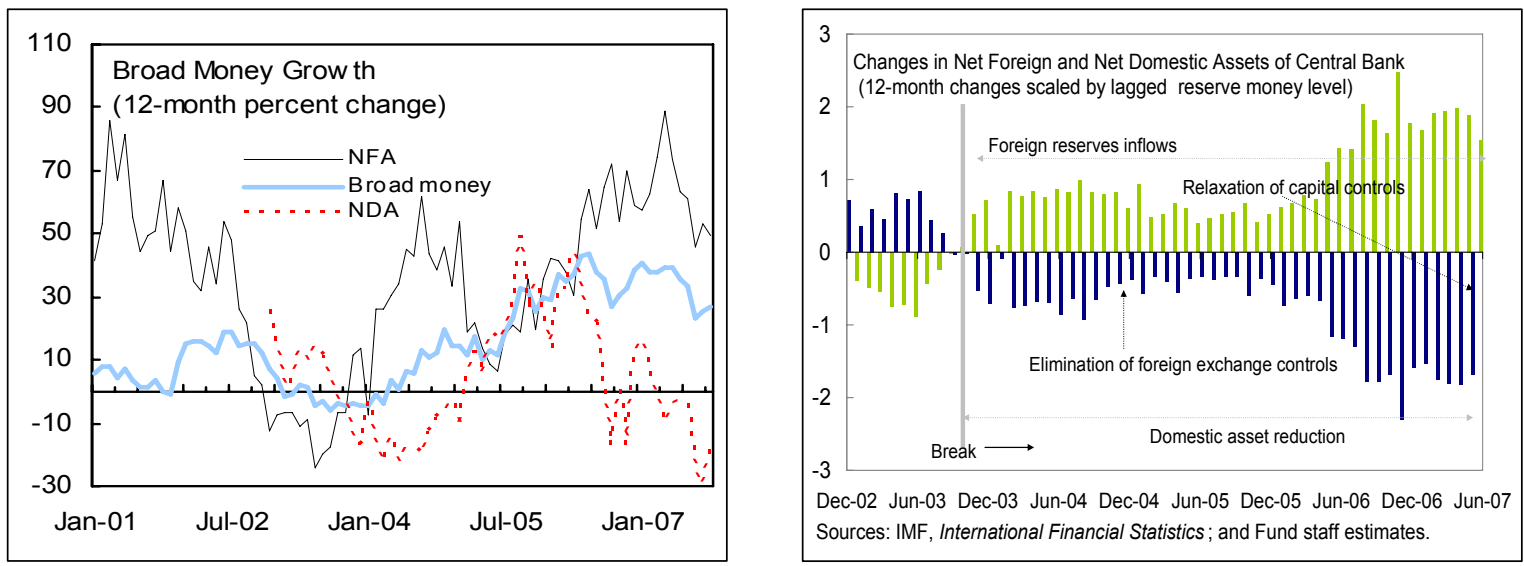

\section{Empirical Analysis}

8. A Vector Error Correction Model (VECR) is used to examine the statistical relationships between CPI inflation and the exchange rate (NEER), broad money, government expenditure, inflation in Papua New Guinea's major trading partners, and 
oil prices. ${ }^{6}$ This study uses simple econometric models that include exchange rate (NEER) and either broad money or government expenditure as endogenous explanatory variables. Model A includes broad money, while Model B includes government expenditure. Results from the exercises are as follows:

- $\quad$ CPI and NEER are negatively correlated. A 1 percent appreciation in the kina is associated with a 0.87 percent decrease in CPI for Model A and 0.59 percent for Model B. $^{7}$

- $\quad$ CPI is positively correlated with broad money and central government expenditure. A 1 percent increase in broad money is associated with a 0.23 percent increase in CPI while a 1 percent increase in central government expenditures is associated with 0.42 percent increase in inflation. ${ }^{89}$

- Inflation is positively correlated with a lagged oil prices. A 1 percent increase in oil price change in a period before is associated with 0.05 percent increase in an inflation change for Model A and 0.06 percent increase for Model B.

- $\quad$ Inflation is positively correlated with the world inflation. Model A suggests a 1 percent increase in inflation in Papua New Guinea's major trading partners is associated with 1.37 percent increase in an inflation change. However, this variable is not statistically significant for Model B.

- $\quad$ Error correction terms suggest that deviations from the equilibrium level are adjusted by 24 percent per quarter for Model A and 29 percent for Model B, meaning it takes about 12 months to adjust full deviations for Model A and 9 months for Model B.

\footnotetext{
${ }^{6}$ Productivity (GDP gap or real GDP per capita) could be an explanatory variable of inflation. However, both the GDP gap and real GDP per capita do not work well for Papua New Guinea; the sign for the GDP gap is opposite to the our expectation, while NEER becomes statistically insignificant when real GDP per capita is included in the model. These results could be related to the poor quality of national accounts data. Nonetheless, given indications that productivity has not improved in recent years, inflationary pressure could be further increased if other conditions are unchanged.

${ }^{7}$ Thomas and al. (2006) estimated the exchange rate pass-through to underlying inflation by using OLS. The result shows the pass-through effect is approximately 50-60 percent.

${ }^{8}$ Including both broad money and government expenditures in a model causes multicollearity problem (the correlation coefficient of broad money growth and government expenditures is about 0.9). Other studies have shown that dropping one of correlated variables is the best way to solve this problem; Pearce and Reiter (1985) discusses the well-known two-stage strategy.

${ }^{9}$ Private credit, related to broad money, could be an explanatory variable of inflation. However, the econometric model becomes divergent if private credit is used instead of broad money.
} 


\begin{tabular}{|c|c|c|c|}
\hline \multicolumn{4}{|c|}{ Results of VECM } \\
\hline & & Model A & Model B \\
\hline \multicolumn{2}{|r|}{ Error Correction Term } & $\begin{array}{l}-0.24 * * * \\
(-0.10)\end{array}$ & $\begin{array}{l}-0.29 * * * \\
(-0.09) \\
\end{array}$ \\
\hline $\begin{array}{c}\text { Endogenous } \\
\text { Variables }\end{array}$ & $\begin{array}{c}\text { NEER } \\
\text { Broad Money } \\
\text { Government Expenditure }\end{array}$ & $\begin{array}{c}-0.87 * * * \\
(-0.06) \\
0.23 * * * \\
(0.07) \\
\ldots \\
\ldots \\
\end{array}$ & $\begin{array}{l}-0.59 * * * \\
(-0.09) \\
\ldots \\
\ldots \\
0.40 * * * \\
(0.08) \\
\end{array}$ \\
\hline $\begin{array}{l}\text { Exogenous } \\
\text { Variables }\end{array}$ & $\begin{array}{c}\text { Oil Price }(\mathrm{t}) \\
\text { Oil Price }(\mathrm{t}-1) \\
\text { Oil Price }(\mathrm{t}-2) \\
\text { Oil Price }(\mathrm{t}-3) \\
\text { Inflation in PNG's Trading Partners }\end{array}$ & $\begin{array}{c}-0.01 \\
(-0.02) \\
0.05 * * \\
(0.02) \\
-0.03 \\
(-0.03) \\
-0.01 \\
(-0.03) \\
1.37 * * \\
(0.57) \\
\end{array}$ & $\begin{array}{c}-0.02 \\
(-0.02) \\
0.06 * * \\
(0.02) \\
0.00 \\
(-0.02) \\
-0.03 \\
(-0.02) \\
0.83 \\
(0.56) \\
\end{array}$ \\
\hline & $\begin{array}{c}R \text {-squared } \\
\text { Adjusted R-squared }\end{array}$ & $\begin{array}{l}0.78 \\
0.62\end{array}$ & $\begin{array}{l}0.76 \\
0.63\end{array}$ \\
\hline \multicolumn{4}{|c|}{$\begin{array}{l}\text { 1/ Quarterly data for } 19951 \mathrm{Q}-20064 \mathrm{Q} \text { are used for estimations. } \\
2 \text { / Coefficients with }{ }^{* * *},{ }^{* *}, \text { and * are statistically significant at } 1,5 \text {, and } 10 \text { percent } \\
\text { criteria respectively. } \\
\text { 3/ Figures in parentheses are standard errors. }\end{array}$} \\
\hline
\end{tabular}

9. As the econometric analyses show, the nominal exchange rate (NEER) is the most important determinant of CPI in Papua New Guinea, followed by government expenditure and broad money. The correlation coefficients of CPI components and economic variables suggest that broad money is highly correlated with nontradable goods such as rent, council charges, and fuel/power and miscellaneous, while NEER has a high correlation with tradable goods such as food; drinks, tobacco, and betel nut; clothing and footwear; and household equipment and operations. ${ }^{10}$ Meanwhile, government expenditure is highly correlated with CPI components across the board.

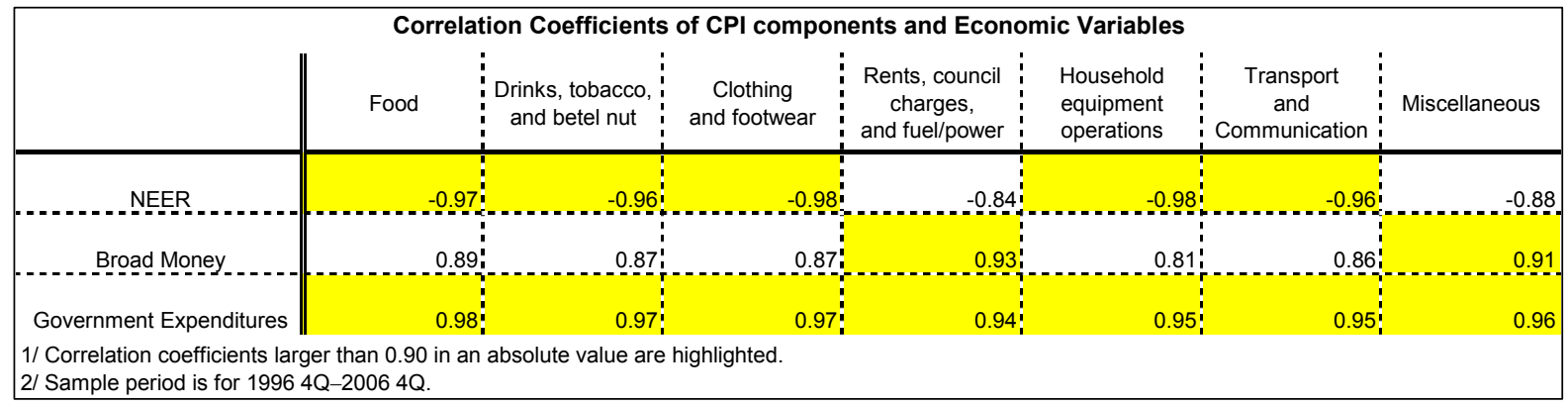

10 "Miscellaneous" includes medical and health care, entertainment, cultural goods and services, and other goods. 


\section{Cross-Country Analysis}

10. Cross-country analysis for twenty countries including Papua New Guinea and its peers suggests that the relationships between inflation and NEER movements, broad money growth, and central government expenditure growth that are observed in Papua New Guinea hold across the board. ${ }^{11}$ The coefficient of inflation and NEER for twenty countries including Papua New Guinea is -0.80 , indicating a 1 percent appreciation in NEER is associated with 0.80 percent decrease in inflation. Meanwhile, the coefficient of inflation and central government expenditure is 0.42 , indicating a 1 percent increase in central government expenditure is associated with 0.42 percent increase in inflation. Similarly, the coefficient of inflation and broad money growth is 0.41 , indicating a 1 percent increase in broad money growth is associated with 0.41 percent increase in inflation.
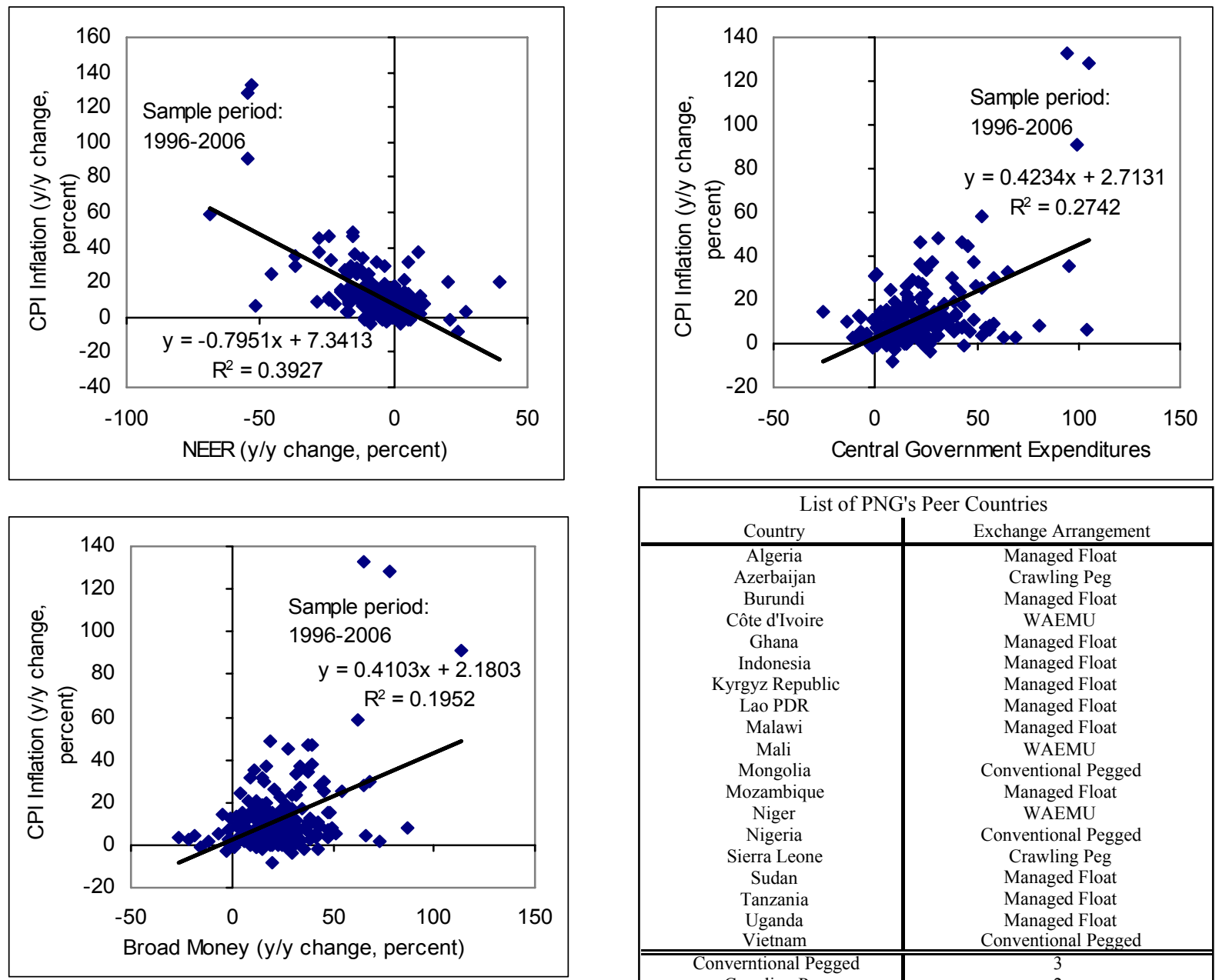

1/ Correlation Coefficients are calculated by the cross-country data on PNG and its peer countries. The sample period is $1996-2006$. 2/ Government expenditures for Mongolia is for "general government."

\begin{tabular}{|c|c|}
\hline \multicolumn{2}{|c|}{ List of PNG's Peer Countries } \\
Country & Exchange Arrangement \\
\hline Algeria & Managed Float \\
Azerbaijan & Crawling Peg \\
Burundi & Managed Float \\
Côte d'Ivoire & WAEMU \\
Ghana & Managed Float \\
Indonesia & Managed Float \\
Kyrgyz Republic & Managed Float \\
Lao PDR & Managed Float \\
Malawi & Managed Float \\
Mali & WAEMU \\
Mongolia & Conventional Pegged \\
Mozambique & Managed Float \\
Niger & WAEMU \\
Nigeria & Conventional Pegged \\
Sierra Leone & Crawling Peg \\
Sudan & Managed Float \\
Tanzania & Managed Float \\
Uganda & Managed Float \\
Vietnam & Conventional Pegged \\
\hline Converntional Pegged & 3 \\
Crawling Peg & 2 \\
Managed Float & 11 \\
Independently Float & 0 \\
WAEMU & 3 \\
1/ Peer countries are selected based on the size of impact of changes in \\
commodity exports on current account balances, foreign exchange regimes, \\
and income levels. \\
\hline \multicolumn{2}{|c|}{} \\
\hline \hline
\end{tabular}

${ }^{11}$ Peer countries are selected based on the size of impact of changes in commodity exports on current account balances, foreign exchange regimes, and income levels. 
11. Papua New Guinea's inflation has been low compared to its peer countries, while broad money has grown more rapidly than its peer countries since 2005. Lower inflation in Papua New Guinea has reflected higher appreciation of the exchange rate and lower increases in government expenditure compared to peer countries. ${ }^{12}$
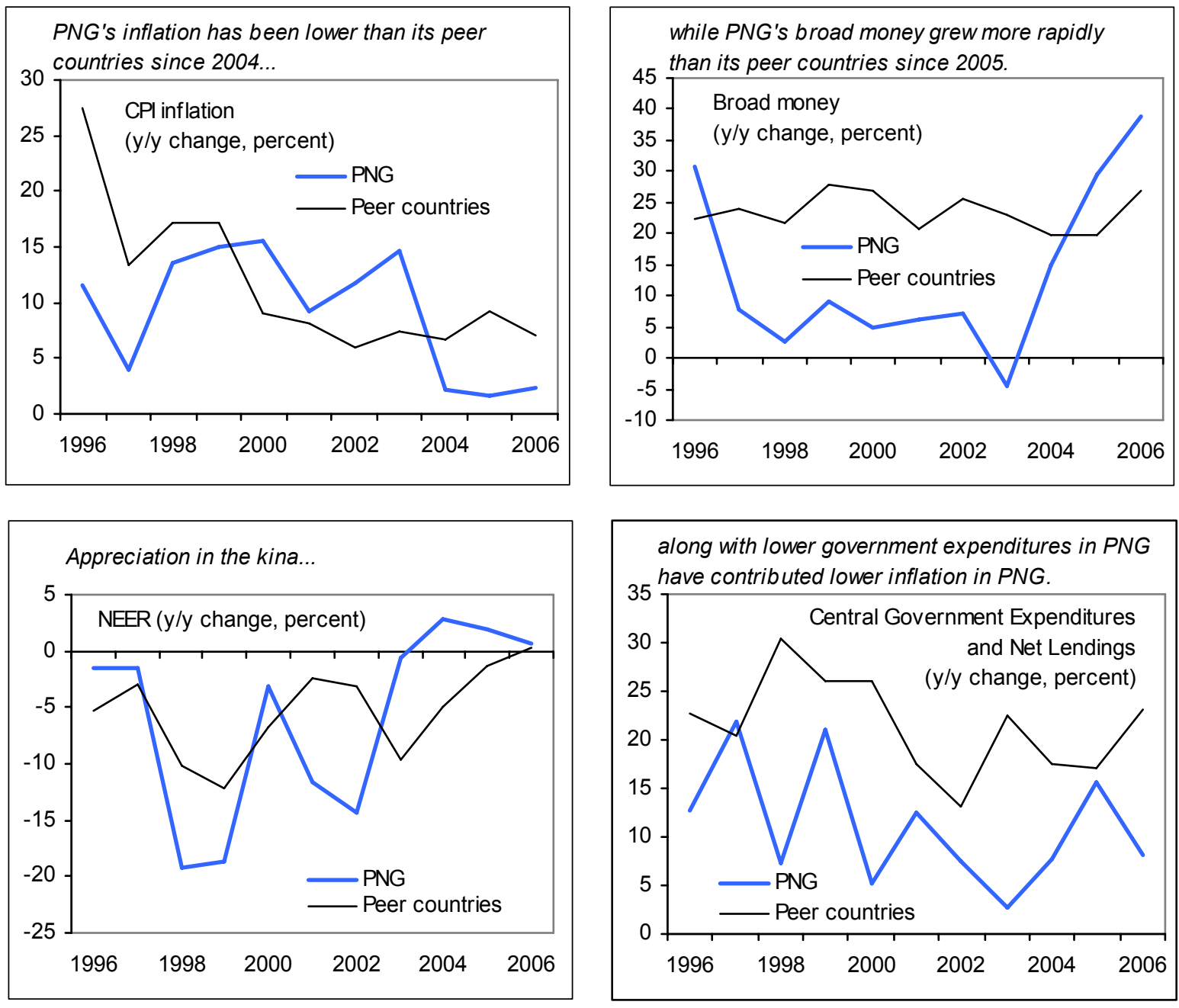

\section{E. Conclusions and Policy Implications}

12. The analyses in this chapter suggest that changes in the exchange rate are the most important determinant of inflation in Papua New Guinea, followed by government expenditure, broad money, and international oil prices. In addition, the BPNG's proactive stance to absorb excess liquidity through open market operations as well as the low volatility in the kina might have contributed to the low inflation. However, looking ahead, the recent rapid

\footnotetext{
${ }^{12}$ Looking at levels rather than growth rates, government expenditure and broad money as a share of nominal GDP have been higher for PNG than for its peer countries: the average of government expenditure as a share of nominal GDP for 1996-2006 is 31 percent for PNG and 23 percent for its peers, while the average of broad money as a share of nominal GDP for 1996-2006 is 34 percent for PNG and 21 percent for its peers.
} 
broad money growth, increased government expenditure, and increased international oil prices could increase inflationary pressures. The results from the empirical analysis indicate that the current equilibrium inflation rate ranges from 5-8 percent. Given the increased inflationary pressures, the BPNG should be prepared to tighten monetary conditions as necessary to counter such pressures. At the same time, given current conditions, it remains appropriate for the BPNG to continue the current exchange rate policy of leaning against the wind to prevent too rapid exchange rate appreciation against the U.S. dollar, and sterilizing the resulting reserve accumulation to help contain inflation, while also balancing concerns regarding the inflationary impact of nominal depreciation on a trade-weighted basis. 


\section{References}

Douglas K. Pearce, Sara A. Reiter, 1985, "Regression Strategies When Multicollinearity Is a Problem: A Methodological Note," Journal of Accounting Research, Vol. 23, No. 1.

Neil R. Ericsson, Eilev S. Jansen, Neva A. Kerbeshian, and Ragnar Nymoen, 1998, "Interpreting a Monetary Conditions Index in Economic Policy," BIS Conference Papers, Volume 6, pp. 237-254, Bank for International Settlements, Basle, Switzerland.

Sampson Thomas, Jeffrey Yabom, Williamina Nindim, and Jacob Marambini, 2006, "Exchange rate pass-through in Papua New Guinea," Pacific Economic Bulletin, Volume 21, No 1, Asia Pacific Press. 


\section{ANNEX: TeChNiCAL APPENDiX}

A Vector Error Correction Model (VECM), which can capture both long-run and short-run relationships for an empirical analysis, is used in the paper. The data set for the estimation is on a quarterly basis, of which CPI data are seasonally adjusted by the Census X-12 while quarterly government expenditure data are calculated by interpolating the annual data in a quadratic-match average way. Independent variables are foreign exchange rate (NEER), broad money, central government expenditure, oil prices, and inflation in Papua New Guinea's major trading partners (import value weighted average of CPI in Australia, Japan, New Zealand, the United States, and developing countries). Oil prices and inflation in Papua New Guinea's major trading partners are assumed to be exogenous variables given Papua New Guinea is a small and open economy (price taker).

\section{Model $A$}

Long run (EC): $\log (C P I)=\alpha \log ($ NEER $)+\beta \log ($ BroadMoney $)+$ Constant

VECM: $\Delta \log \left(C P I_{t}\right)=-\gamma E C_{t-1}+\sum \eta \Delta \log \left(C P I_{t-1 / t-4}\right)+\sum \lambda \Delta \log \left(\right.$ BroadMoney $\left._{t-1 / t-4}\right)$

\section{Model B}

$$
+\sum \pi \Delta \log \left(\text { Oilprices }_{t / t-3}\right)+\psi \Delta \log \left(\text { WorldCPI }_{t}\right)+\text { Constant }
$$

Long run $(\mathrm{EC}): \log (C P I)=\alpha \log ($ NEER $)+\chi \log ($ GovernmentExpenditures $)+$ Constant

VECM: $\Delta \log \left(C P I_{t}\right)=-\gamma E C_{t-1}+\sum \eta \Delta \log \left(C P I_{t-1 / t-3}\right)+\sum v \Delta \log \left(\right.$ GovernmentExpenditures $\left._{t-1 / t-3}\right)$ $+\sum \pi \Delta \log \left(\right.$ Oilprices $\left._{t / t-3}\right)+\psi \Delta \log \left(\right.$ WorldCPI $\left._{t}\right)+$ Constant

As unit root tests, Augmented Dickey-Fuller (ADF) and Phillips-Peron (PP) tests are applied. Existence of I(1) process for all variables except for NEER were supported by both tests while I(1) process for NEER is supported only by PP tests. Existence of at least one cointegration among the variables for both model A and B was suggested by the cointegration tests. Expected signs for correlation coefficients are as follows:

\section{Long-run Relationship (endogenous variables)}

- Exchange rate: appreciation (depreciation) of the kina NEER expects to lower the inflation $(\alpha<0)$.

- $\quad$ Broad money: increase in broad money expects to increase inflation $(\beta>0)$.

- Government expenditure: increase in government expenditures expects to increase inflation $(\chi>0)$.

\section{VECM (short-run relationship/exogenous variables)}

- Oil prices: increase in oil prices (with time lags) expect to increase inflation $(\pi>0)$.

- $\quad$ Foreign inflation: increased inflation abroad expects to increase PNG's inflation $(\psi<0)$ 


\title{
II. The Monetary Transmission Mechanism in Papua New Guinea ${ }^{1}$
}

\begin{abstract}
A. Introduction
1. The Bank of Papua New Guinea (BPNG) has made progress towards attainment of an independent framework for the conduct of its monetary policy. From a system of controlled monetary management prior to 1994, following the move to a floating exchange rate that year, it has gradually moved to a market-based system of monetary management with price stability as its objective.
\end{abstract}

2. The main stimulus for this change was the significant reform of the banking and financial sector undertaken as part of a stabilization program begun earlier this decade. In 2000, the Central Bank Act was passed granting the central bank the needed independence for the conduct of its monetary policy. Other key reforms implemented since then include passage of the Financial Institutions Act and the Insurance Act, and reform of the pension system. Together, these reforms have precipitated a rapid increase in the size of the overall financial sector since 2000 (see Chapter 4).

3. Against this background of change in the institutional structure and size of the financial sector, an informed assessment of how and by what magnitude policy changes affect the economy would assist the successful design and implementation of monetary policy. This paper therefore analyzes the workings and effectiveness of the monetary transmission mechanism in Papua New Guinea. The remainder of the paper is organized as follows: Section B describes the current institutional structure in Papua New Guinea. Section $\mathrm{C}$ looks at interest-rate pass through, while Section D considers the evidence from vector autoregression analysis on the relationship between monetary policy variables and output and prices. Finally, Section E sets out the paper's conclusions and policy implications.

\section{B. Background: Institutional and Operational Framework}

\section{As part of a broader agenda of financial sector reform, a new Central Bank Act} was enacted in June 2000.

- This Act set price stability as the primary macroeconomic goal of the BPNG and granted considerable policy independence in its pursuit. A Monetary Policy Committee was subsequently formed with responsibility for formulating appropriate policies that would help attain a stable inflation environment and macroeconomic stability.

\footnotetext{
${ }^{1}$ Prepared by Ebrima Faal and Agnes Isnawangsih. This chapter is based on a presentation delivered at the BPNG in Port Moresby in November 2007 and benefits from comments received at that time.
} 
- The central bank was then free to use whatever instruments it possessed to achieve price stability. To this end, the BPNG is required to publish semi-annual monetary policy statements, setting out its outlook for the economy and the intended policy response over the coming six months.

- The new Act also sought to reduce the effect of fiscal operations on monetary management by limiting the amount that the government can borrow from the central bank. ${ }^{2}$

- Papua New Guinea has also since adopted the principles of universal banking, promoted competition in the financial system through the nondiscriminatory treatment of foreign investment, privatized a public bank, introduced prudential regulations consistent with the Basle standards, and improved bank supervision significantly. In addition, a stock market and mutual funds started operations.

5. In determining its monetary policy stance, the BPNG reviews a broad range of factors influencing the evolution of inflation. These include developments in the global economy, the balance of payments, fiscal operations of the government, domestic activity and the exchange rate. Although the BPNG has price stability as its ultimate objective, it does not have an explicit inflation-targeting framework. ${ }^{3}$

- The market component of Papua New Guinea's economy is relatively open, with nearly one-half of GDP exported and a larger proportion of consumption imported. Appropriately, Papua New Guinea has a managed floating exchange rate regime that can help to buffer the domestic economy from external shocks. However, this also implies that the exchange rate does play a significant role in the transmission of monetary policy. While not targeting a particular level of the kina, the BPNG does seek to reduce short-term and seasonal volatility of the exchange rate through foreign exchange market intervention.

- The BPNG uses a reserve money framework to conduct monetary policy operations. Through market instruments it seeks to control the growth of reserve money, which in turn, through the money multiplier, is expected to determine the evolution of broader monetary aggregates in a manner that would achieve the price objective.

\footnotetext{
${ }^{2}$ The Bank of Papua New Guinea can provide a temporary advance to the government (limited originally to K100 million, and since adjusted for inflation) for a period of no longer than six months. However, the central bank can also hold government securities for monetary policy purposes, which are not subject to the borrowing limit.

${ }^{3}$ In part, this reflects the fact that there are insufficient timely data available, particularly on economic activity, for accurate inflation forecasts that would form the basis for a quantitative inflation target.
} 
- On a day-to-day basis, the BPNG gauges the tightness of its policy by the system-wide level of Exchange Settlement Account (ESA) balances. ${ }^{4}$ These are accounts held at the BPNG by each commercial bank.

6. In implementing monetary policy, the Kina Facility Rate (KFR) plays a key role. Since February 2001, the BPNG has used the KFR as an indicator of the stance of monetary policy. Operationally, the KFR determines the rates on the central bank's Kina Facility and Repurchase Agreement Facility (the latter by a margin relative to the KFR determined at the BPNG's discretion). However, the KFR has a broader role as the official benchmark rate used to signal changes in the policy stance. Decisions to vary or keep unchanged this rate are explained publicly relative to the outlook for achieving the BPNG's inflation objective.

- In practice, changes in the KFR have been infrequent. It has remained unchanged at 6 percent since September 2005. In addition, average KFR changes measured over one month, at between 50 and -100 basis points, are small relative to comparator policy rate changes in transition countries.

- Another instrument actively used to manage liquidity and influence interest rates are open market operations, most recently using central bank bills and repurchase operations, which allow it to conduct open market operations at a higher frequency than the weekly treasury

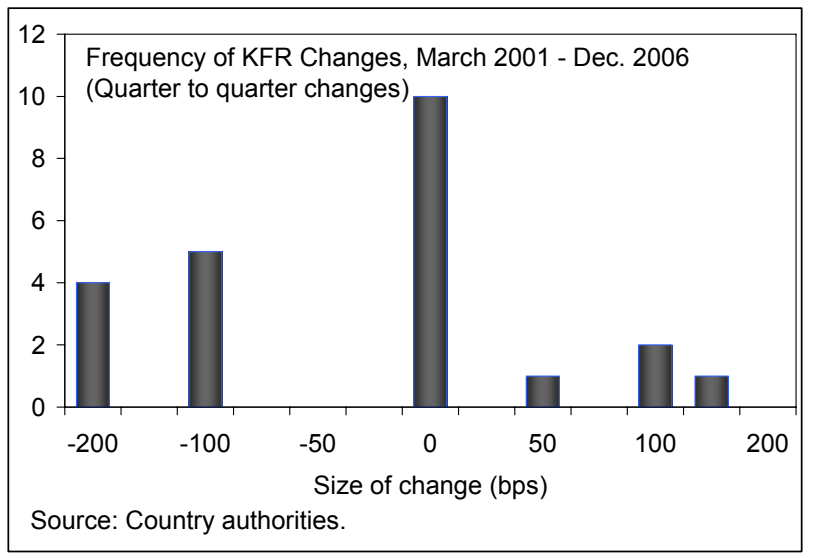
bill auction cycle. Also, the Repurchase Agreement Facility (RAF) operates as an overnight unsecured borrowing and lending arrangement; as noted above, its interest rate is based on the prevailing KFR.

- The Kina Facility Rate and the RAF rate together anchor the short end of the yield curve. However, treasury bill rates have moved below the deposit rate for the Kina Facility in recent years, possibly reflecting market expectations for further reductions in the KFR (Figure 3). Given the size and persistence of the deviation, it may also reflect the KFR's loss of credibility as a signal of the BPNG's policy intentions.

\section{The BPNG can also influence liquidity conditions on a daily basis through its} interventions in the foreign exchange market. The low interest rates associated with current

\footnotetext{
${ }^{4}$ All interbank transfers are settled through these accounts, which represent "same-day" funds. The balances in these accounts do not include deposits used to satisfy reserve requirements, and therefore ESA levels represent the excess reserves of the banking system. The level of ESA balances is affected by many factors beyond the control of Bank of Papua New Guinea, including government expenditure and tax collections, foreign exchange transactions, and changes in the check float.
} 
monetary conditions of high liquidity could lead to short-term capital outflows. If this occurred, and the BPNG sold foreign exchange to ease the resulting pressure on the exchange rate, it simultaneously would withdraw liquidity. However, the recent experience has been that the BPNG has generally been able to manage liquidity using its domestic instruments, and so has been able to maintain an adequate level of reserves.

\section{In practice, the main instrument for monetary policy has been the repurchase} facility (or repo) rate. As indicated in the monetary policy transmission mechanism depicted in Figure 2, the repo rate has direct effects on other variables in the economy, such as other interest rates, the exchange rate, money and credit, other asset prices and decisions on spending and investment. Thus, changes in the repo rate affect the demand for and supply of goods and services. Relative demand pressure and the supply capacity of the economy then becomes a key factor influencing domestic inflationary pressures. In addition, imported inflation, influenced by exchange-rate movements, plays an important role in contributing to price movements. ${ }^{5}$

Figure 2. Papua New Guinea: The Transmission Mechanism for Monetary Policy

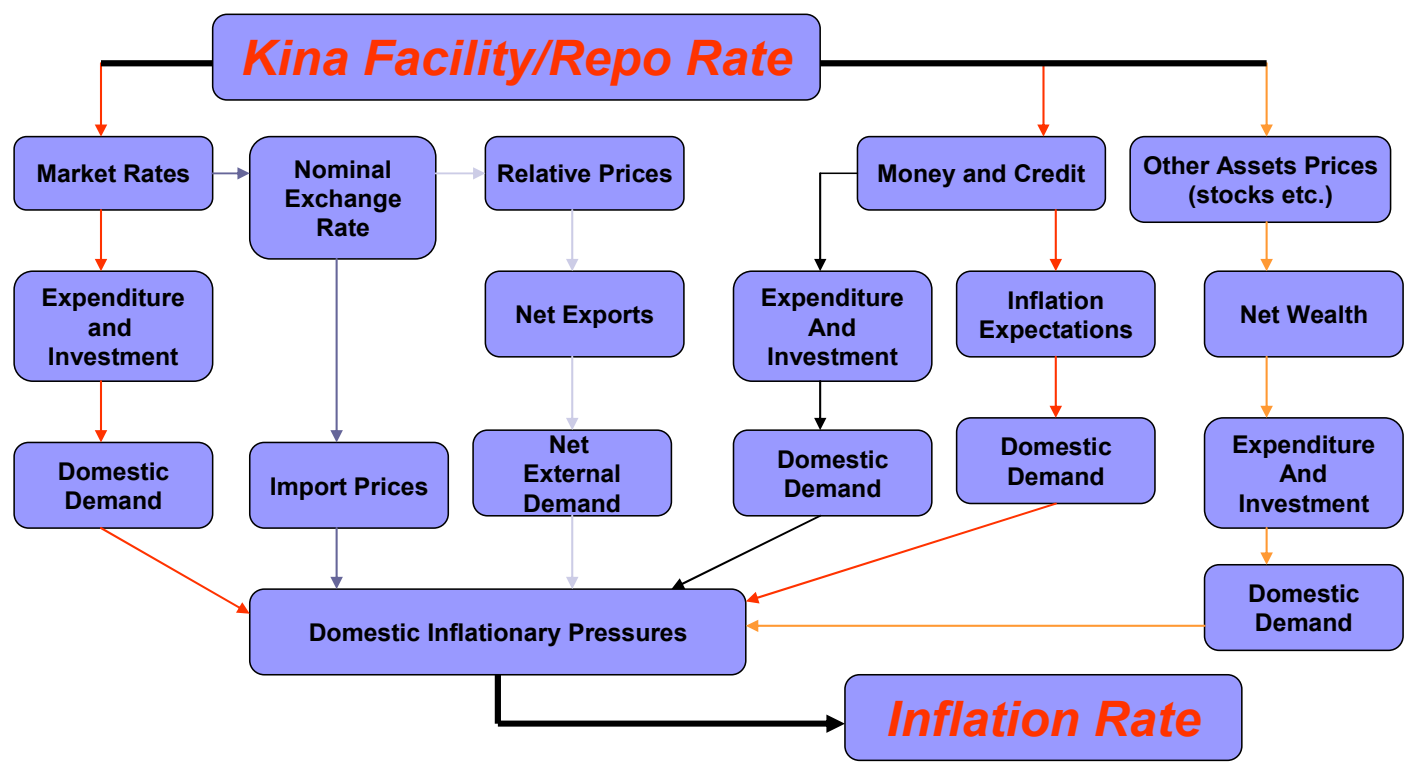

\section{Stylized Facts: Interest Rate Pass-Through}

9. To achieve the objectives of monetary policy, the key transmission channel is the pass-through from the repo rate to other interest rates. Trends in nominal and real interest rates suggests that the repo and other interest rates have moved in the same direction since 2001 (Figure 3). Since 2003, repo rates have been declining, as have other rates. Simple OLS regressions of the contemporaneous and lagged KFR on the repo rate and of the repo rate

\footnotetext{
${ }^{5}$ Papua New Guinea moved to a floating exchange rate system in September 1994.
} 
on market rates are used to investigate interest rate pass-through. The results show that changes in the KFR translate quickly into changes in the repo rate (Table 1), as would be expected. However, changes in policy rates do not appear to translate as quickly or fully to market-determined interest rates. For each one percentage point increase in the repo rate, the Treasury bill rate changes by 75 basis points. Cross correlations of interest rates with credit, output and prices display mixed results (Table 2). While the repo rate appears to be positively correlated with inflation, it seems to have little relationship to output and credit.

Table 1. Interest Rate Pass-through

(Regression results, 2001M1 - 2006M12)

\begin{tabular}{|c|c|c|c|c|c|c|}
\hline & \multicolumn{4}{|c|}{$\begin{array}{l}\text { Dependent Variable } \\
\text { Changes in Tbill rate }\end{array}$} & \multicolumn{2}{|c|}{ Changes in Lending rate } \\
\hline & Coefficient & T-statistics & Coefficient & T-statistics & Coefficient & T-statistics \\
\hline Constant & -0.02 & -0.50 & $\ldots$ & $\ldots$ & $\ldots$ & $\ldots$ \\
\hline Changes in Kina Facility rate & 0.89 & 14.83 & $\ldots$ & $\ldots$ & $\ldots$ & $\ldots$ \\
\hline Adjusted R-squared & 0.76 & $\ldots$ & $\cdots$ & $\cdots$ & $\cdots$ & $\cdots$ \\
\hline Constant & $\ldots$ & $\ldots$ & -0.07 & -0.73 & -0.10 & -2.23 \\
\hline Changes in Repo rate & $\ldots$ & $\ldots$ & 0.75 & 4.25 & 0.01 & 0.16 \\
\hline Adjusted R-squared & $\ldots$ & $\ldots$ & 0.21 & $\ldots$ & 0.00 & $\ldots$ \\
\hline
\end{tabular}

Source: Fund staff calculations.

Table 2. Cross-Correlations of Changes in the Repo rate and Select Variables, 2001M2-2006M12

\begin{tabular}{ccccccccc}
\hline & \multicolumn{2}{c}{ Headline inflation } & \multicolumn{2}{c}{ Core inflation } & \multicolumn{2}{c}{ Credit } & \multicolumn{2}{c}{ Real GDP Growth } \\
Time & Lag & Lead & Lag & Lead & Lag & Lead & Lag & Lead \\
\hline 0 & 0.24 & 0.24 & 0.26 & 0.26 & -0.11 & -0.11 & 0.03 & 0.03 \\
1 & 0.32 & 0.08 & 0.37 & 0.24 & 0.00 & 0.11 & -0.01 & 0.03 \\
3 & 0.33 & 0.09 & 0.43 & 0.20 & -0.03 & -0.20 & -0.04 & 0.05 \\
6 & 0.10 & 0.08 & 0.30 & 0.03 & 0.06 & 0.07 & -0.15 & 0.23 \\
9 & 0.10 & 0.05 & 0.24 & -0.11 & -0.03 & -0.15 & -0.18 & 0.01 \\
12 & 0.10 & -0.10 & 0.13 & -0.13 & -0.09 & 0.02 & -0.29 & 0.04 \\
18 & -0.11 & -0.24 & -0.16 & -0.31 & 0.10 & -0.06 & -0.15 & 0.07 \\
24 & -0.07 & -0.02 & -0.18 & -0.04 & 0.13 & 0.01 & 0.09 & 0.05 \\
\hline
\end{tabular}

Source: Fund staff calculations. 
Figure 3. Papua New Guinea: Key Financial Variables
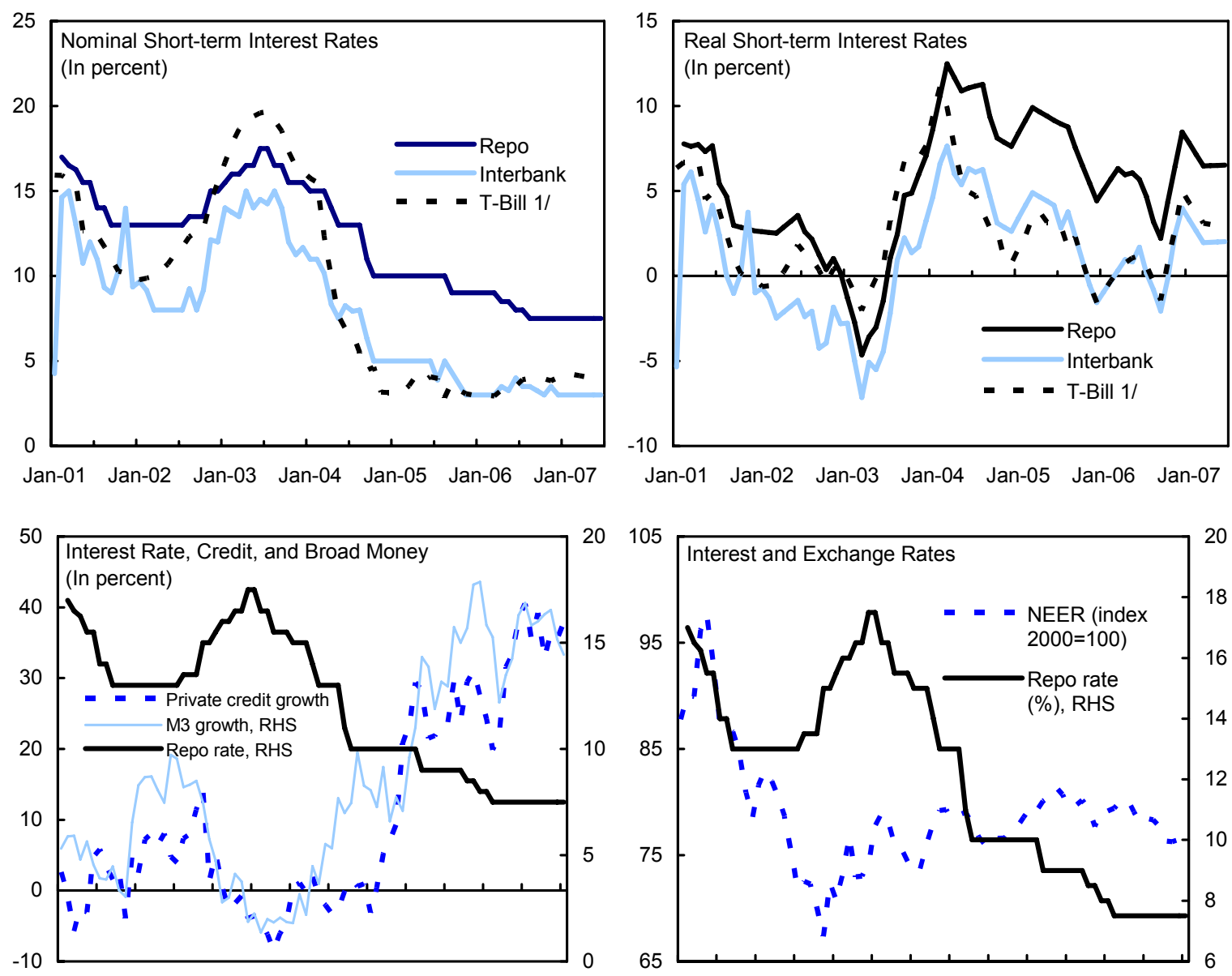

Jan-01 Jan-02 Jan-03 Jan-04 Jan-05 Jan-06 Jan-07

Jan-01 Jan-02 Jan-03 Jan-04 Jan-05 Jan-06 Jan-07
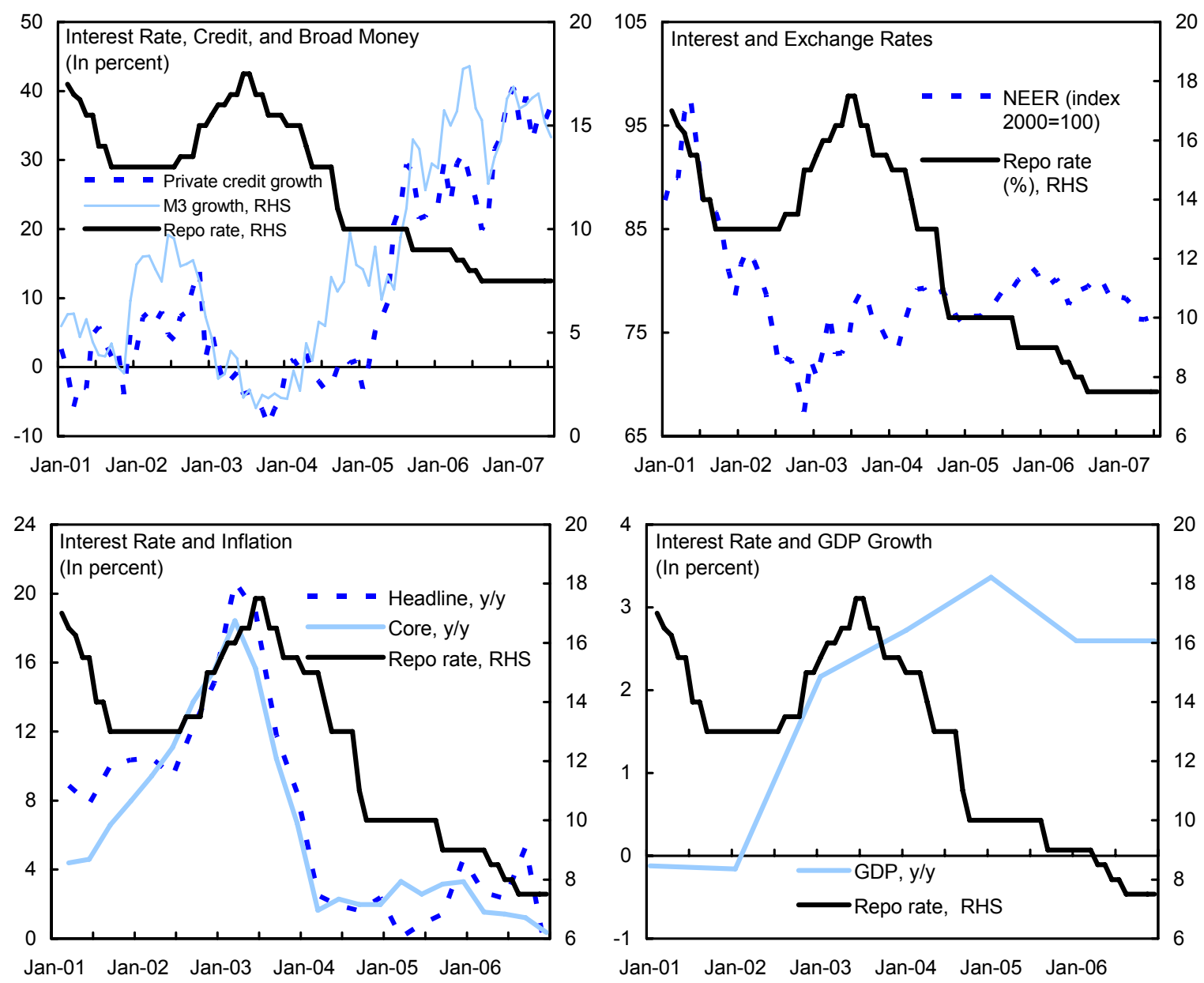

Sources: IMF, International Financial Statistics and Information Notice System; Country authorities; and Fund staff calculations.

1/ From Sept 2005 onward using Central Bank Bills. 


\section{Evidence From Vector Autoregression Analysis}

\section{This section examines the relationships between monetary policy variables and} output and prices using a Vector Autoregression Analysis (VAR). The VAR has several advantages:

- VARs have been used extensively in the study of monetary policy transmission processes as they represent dynamic systems of equations in which the current level of each variable in the system depends on past movements in that variable and all other variables in the system. A key advantage of the methodology is that it imposes minimal restrictions on how monetary shocks affect the economy.

- Moreover, the methodology recognizes explicitly the simultaneity between monetary policy and macroeconomic developments; that is, the dependence of monetary policy on other economic variables, as well as the dependence of economic variables on monetary policy.

- Once estimated, VARs can be used to simulate the response over time of any variable in the set to either an own disturbance or a disturbance to any other variable in the system and to produce a variance decomposition of the variable.

The mathematical representation of a VAR is:

$$
y_{t}=\alpha y_{t-1}+\alpha_{2} y_{t-2}+\ldots \ldots \ldots \ldots \ldots \ldots \ldots \ldots+\alpha_{p} y_{t-p} \varepsilon_{t}
$$

Where $y_{t}$ is a $k$ vector of endogenous variables, $\alpha_{1, \ldots . .} \alpha_{p}$ are matrices of coefficients to be estimated, and $\varepsilon t$ is a vector of innovations that may be contemporaneously correlated but are uncorrelated with their own lagged values and uncorrelated with all of the right-hand side variables. Given that only lagged values of the endogenous variables show on the right-hand side of the equations, simultaneity is not a problem, and OLS yields consistent estimates.

11. The VAR is identified using recursive Cholesky decomposition. As the reduced-form errors are typically correlated, the Cholesky decomposition isolates the underlying structural errors by recursive orthogonalization, with the innovation in the first equation untransformed, the innovation in the second equation taken as orthogonal to the first, and so on. 


\section{Data and choice of variables ${ }^{6}$}

12. The analysis focuses on the period since the passage of key financial sector reforms, including the Central Bank Act, and considers the effects of three policy instruments, namely interest rates, the exchange rate, and the money supply. We use the repo rate, which is (in connection with the KFR), the key short-term interest rate used by the BPNG to signal its monetary policy stance. The second policy-related variable is the nominal exchange rate $(x)$. We focus on the nominal effective exchange rate (NEER) to examine the effects of exchange rate changes on output and prices. ${ }^{7}$ Output is measured as real GDP $(y)$ and the consumer price index $(p)$ is taken as the measure of the general price level. All data are expressed in natural logs and are seasonally adjusted using ARIMA X12, with the exception of the repo rate, which is in levels and not seasonally adjusted.

\section{The Augmented Dickey-Fuller (ADF) test suggests that the null hypothesis that}

the variables are $I(1)$ cannot be rejected. Given that the monetary transmission mechanism is a short-run phenomenon, an analysis of the economy's long run behavior is not carried out in this paper. This allows us to conduct the analysis in levels, thereby allowing for implicit cointegrating relationships in the data. ${ }^{8}$ The lag length of the VAR estimation was selected using the Akaike (AIC) and Schwartz (SC) Information Criteria, and the residuals were tested for autocorrelation. Both tests suggest a lag of the first order, and the Lagrange Multiplier Test suggests that the residuals are not serially correlated.

\section{The Basic Model}

14. In the baseline model, the vector of endogenous variables consists of real GDP $\left(y_{t}\right)$, the consumer price index $\left(p_{t}\right)$, repo rate $\left(\right.$ repo $\left._{t}\right)$, and the nominal exchange rate (neer $\left.)_{t}\right)$ :

$$
Y=\left[y_{t}, p_{t}, \text { repo }_{t}, \text { neer }_{t}\right]
$$

The ordering of the variables was based on the speed with which the variables respond to shocks. Real output is assumed to be the least responsive, as would be expected for a small, open, developing economy, like Papua New Guinea's, with many structural rigidities. A fundamental assumption is that in the short run, shocks to the policy variables have no

\footnotetext{
${ }^{6}$ Monthly data for 2001-06 are used for the econometric analyses. The annual GDP series is converted into a monthly series using quadratic match sum feature in Eviews and the quarterly CPI series is converted using the linear match last feature.

${ }^{7}$ Using the NEER as opposed to a real effective exchange rate makes it easier to distinguish the exchange rate channel from other channels.

${ }^{8}$ Most of the empirical literature on VARs has tended to estimate VARs that are unrestricted in levels (Favero, 2001). Sims, Stock, and Watson (1990) show that if enough of the variables are cointegrated, an analysis in levels is still correct because the ordinary least squares (OLS) estimator of the reduced-form VAR efficiently estimates the cointegrating relationship.
} 
contemporaneous impact on output and prices due to the real sector's sluggish reaction to monetary and exchange rate shocks. The nominal interest rate responds contemporaneously to shocks to output and prices, but not to changes in financial variables. Finally, the nominal exchange rate responds contemporaneously to all types of shocks. ${ }^{9}$

\section{Impulse responses and variance decomposition}

15. To observe the influence of monetary policy on output and prices, we look at the impulse response functions (Figure 4). The results are summarized as follows:

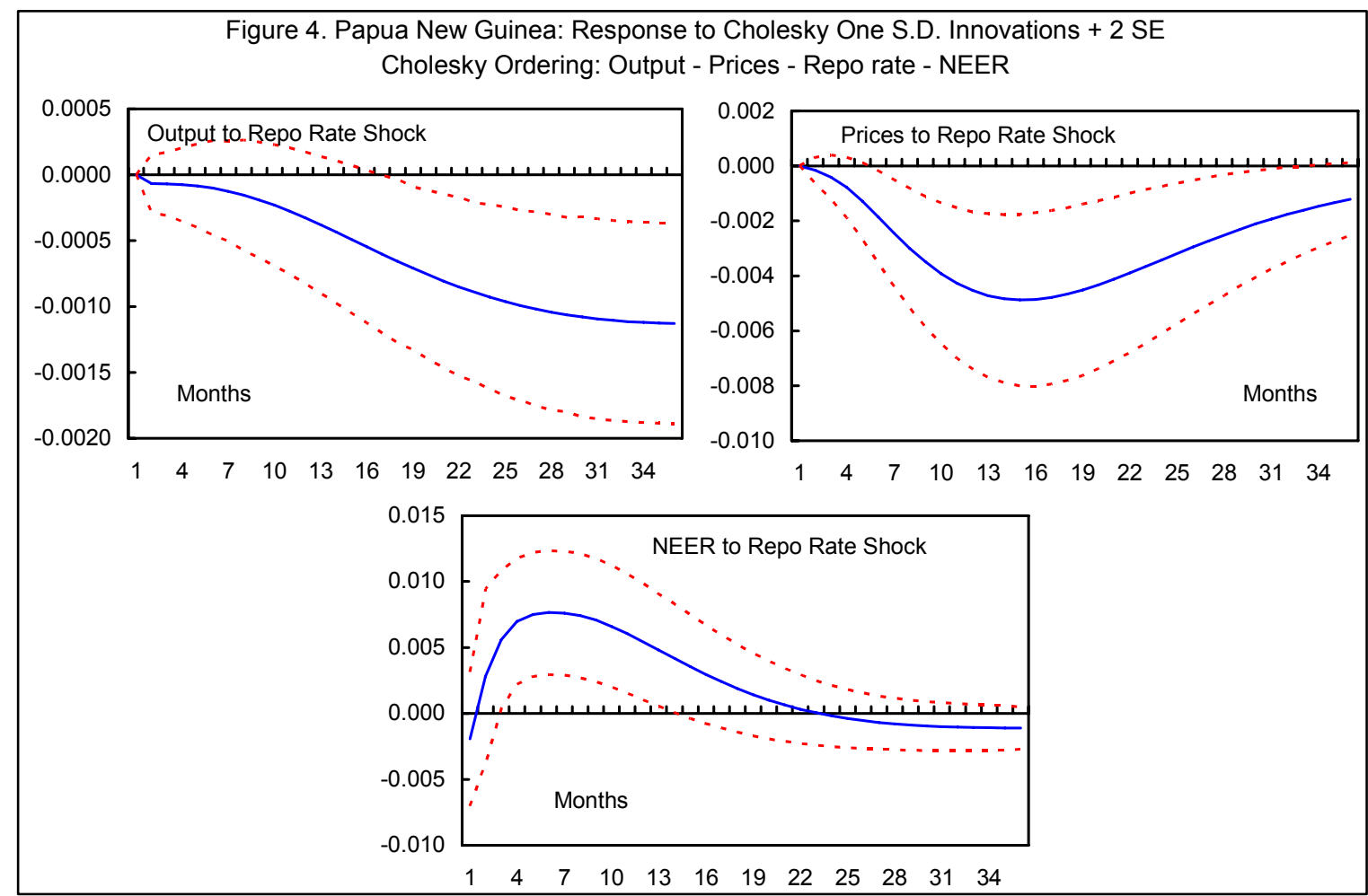

- An unexpected, temporary rise in the repo rate tends to be followed by a sluggish, but persistent decline in output. Variance decomposition indicates that, after 2 years, monetary policy accounts for 42 percent of the fluctuation in output, with own shocks accounting for broadly the amount of the variance.

- An unexpected, temporary rise in the repo rate is followed by a decline in prices, that is significant between 5 to 17 months, peaking after around 15 months following the shock.

\footnotetext{
${ }^{9}$ Alternative orderings of the variables in the VAR produced broadly similar qualitative findings as in the baseline model.
} 
- Likewise, the nominal exchange rate responds strongly to an exogenous increase in the repo rate. An unexpected and temporary rise in the repo rate tends to be followed by an immediate nominal appreciation, with the impact culminating 9-12 months after the shock.

\section{i. Interest Rate Channel}

\section{To examine the interest rate channel more closely, we added to the basic model} (Equation 2) the lending rate for new loans. The variables in this expanded VAR have the following ordering: real output, prices, repo rate, lending rate on new loans, and NEER. Figure 5 presents impulse responses stemming from innovations in monetary policy (increase in the repo rate) and bank lending rates. The lending rate responds immediately and significantly to an unexpected change in the repo rate. Output and prices, however, do not respond significantly to lending rate shocks. The results highlight the transmission of changes in the key policy interest rate to other interest rates in the economy.

\section{Importantly, the results also highlight the weakness of the interest rate channel in} Papua New Guinea, as changes in bank lending rates do not seem to affect economic activity and prices. Variance decomposition suggests that, after two years, interest on new lending account for 11 percent of the fluctuation in output, and just 2 percent of the fluctuation in prices.

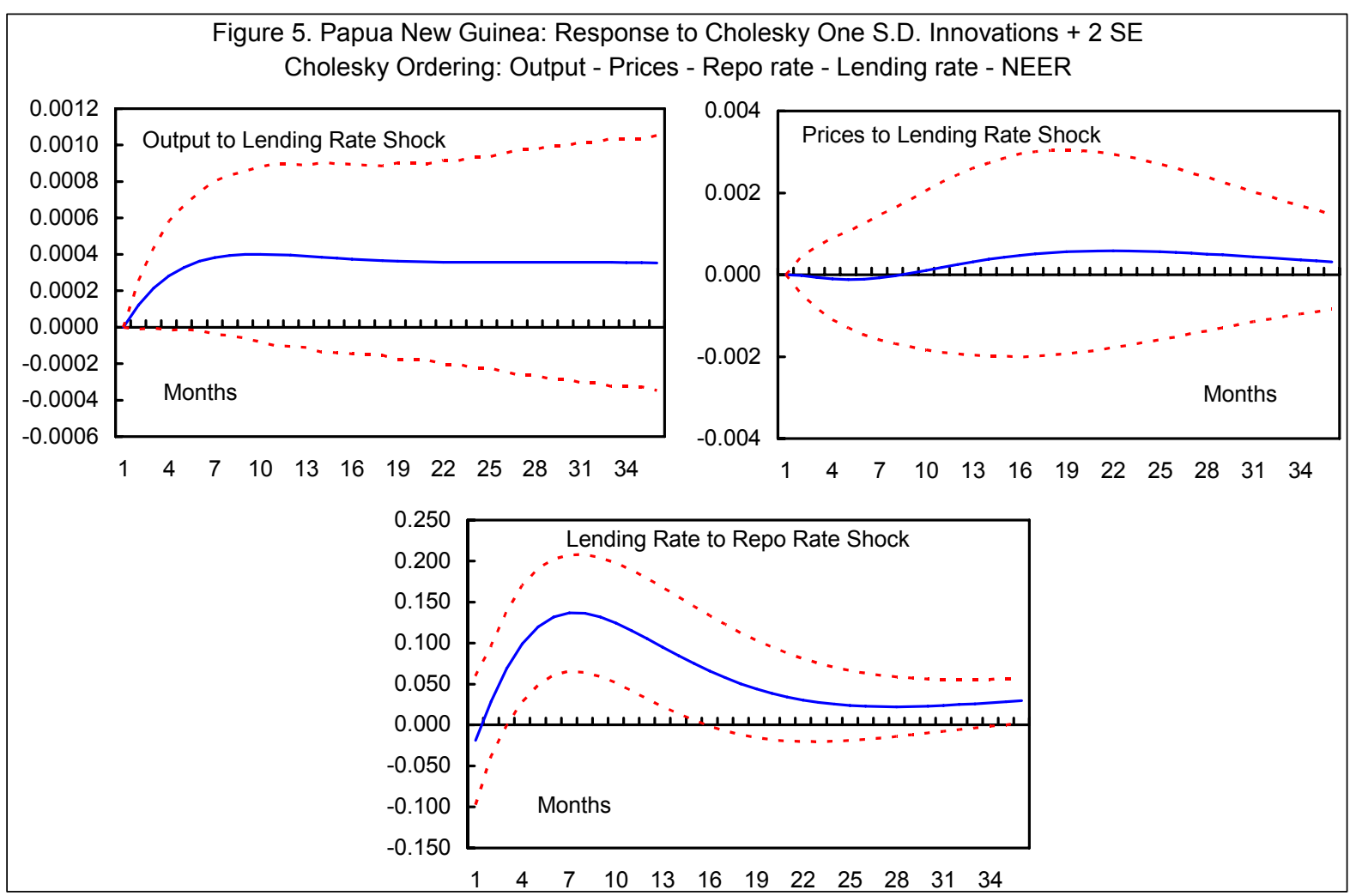




\section{ii. Bank Lending Channels}

\section{Bank credit}

18. To examine the importance of credit in the monetary transmission mechanism, we included the natural log of seasonally adjusted domestic credit in the VAR. The variables in this expanded VAR have the following ordering: real output, prices, bank credit, and the repo rate. Bank credit appears to be important for the monetary transmission mechanism and a significant source of independent shocks to prices. A shock to bank loans results in an almost immediate increase in prices that is significant for about a year (Figure 6). Variance decomposition suggests that, after one year, credit accounts for 15 percent of the fluctuation in prices (Annex, Table 1).

\section{Shocks to bank credit do not appear to elicit an output response that conforms to} what one would expect from the theory-i.e., a positive shock to credit results in a negative output response. This result may be explained by the still relatively modest share that credit to the economy has in total bank assets. Commercial banks with limited credit assessment capacity, in an environment where property rights are not adequately defined, and where corporate governance is weak, have tended to invest their funds in government securities rather than in credit portfolios.

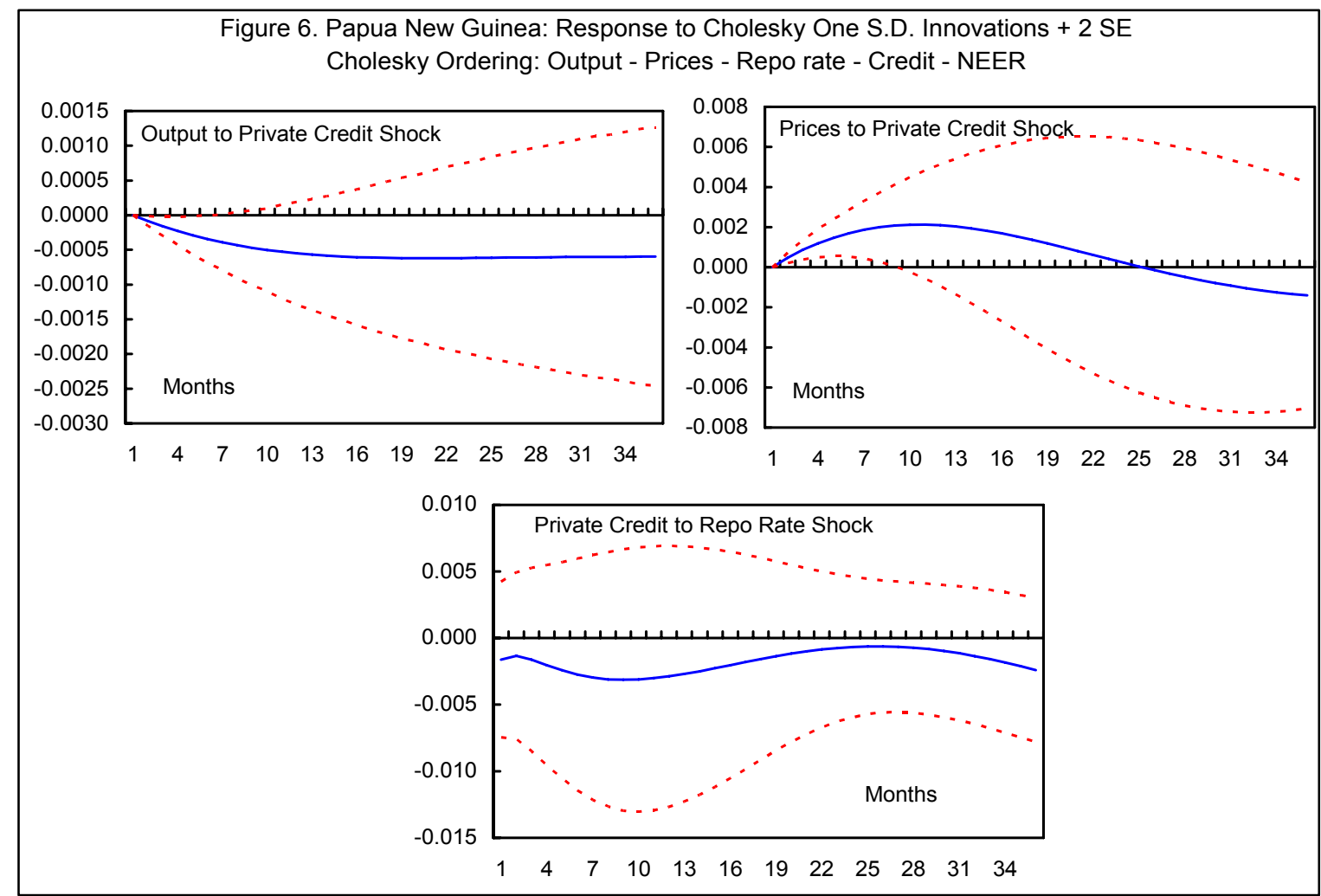




\section{Bank reserves}

20. To examine the issue of whether changes in the bank reserves have implications for output and prices in Papua New Guinea, we add bank reserves to Equation 2. As can be seen from Figure 7, the impulse response of output and prices to a change in bank reserves is not significant. Variance decomposition suggests that, after two years, a shock to reserve money account for only $2 \frac{1}{2}$ percent of the fluctuation in output, and only 2 percent of the fluctuation in prices. These results can be explained by structural rigidities in the banking system, including commercial banks' preference to invest in government paper rather than lending operations. The results are consistent with Saxegaard (2006), which uses a threshold vector autoregression model for a number of Sub-Saharan African countries and finds that excess liquidity in the region weakens the monetary transmission mechanism, and thus the ability of monetary authorities to influence demand conditions in the economy.

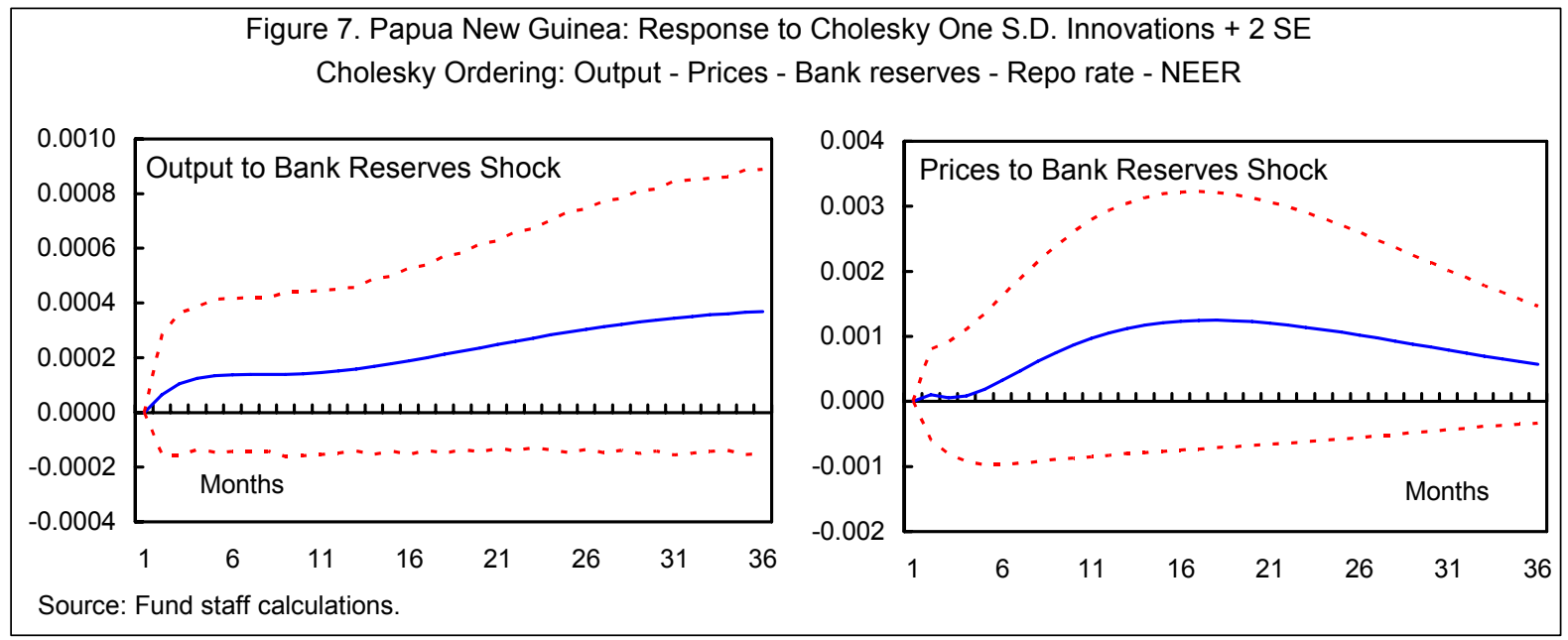

\section{iii. Exchange Rate Channel}

21. Evidence on the exchange rate channel suggests that prices respond strongly to the exchange rate. An appreciation of the NEER results in an almost immediate (within 2 months) decline in prices, which is significant for 10 months after the initial shock. The rapid pass-through of exchange rate changes to prices is consistent with findings from other countries. The results suggest that the exchange rate plays a significant role for monetary transmission in Papua New Guinea. 


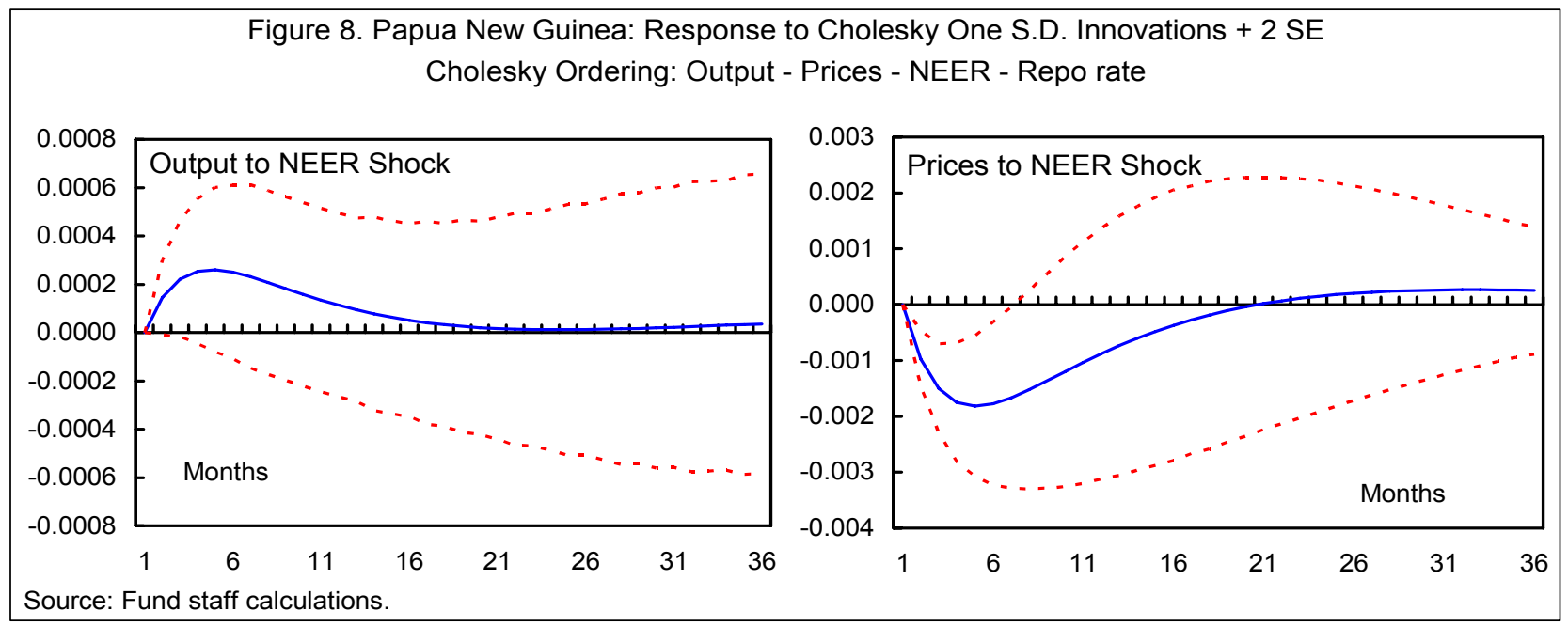

\section{E. Conclusions And Policy Implications}

\section{To gain insights into the workings of the Papua New Guinea economy, we} investigated various channels of the monetary transmission mechanism. While the results should be interpreted with some caution given the level of noise in the data, evidence presented in this paper suggests that monetary policy has been successful in influencing prices and market interest rates. It has been, however, less successful in influencing domestic output.

- Policy instrument (repo): We find evidence to support the view that changes in the BPNG's key policy instrument (the repo rate) have a significant and rapid impact on prices. Changes in the repo rate also affect output sluggishly, and with a significant lag. An unexpected and temporary rise in the repo rate also tends to be followed by nominal exchange rate appreciation.

- Bank lending rate: The lending rate responds immediately and significantly to an unexpected change in the repo rate. Output and prices, however, do not respond significantly to lending rate shocks.

- Bank credit: We find no statistical link in our data between monetary policy and bank credit, nor between bank credit and economic activity. Bank credit appears, however, to be an important source of independent shocks to prices.

- Bank reserves: Our results also show that monetary policy does not seem to have an effect on bank reserves. In addition, the response of output and prices to a change in bank reserves is not significant. These result could be explained by structural rigidities in the banking system, including commercial banks' preference to invest in government paper, despite a significant amount of excess liquidity. 
- Exchange rate: The nominal exchange rate responds immediately and significantly to an unexpected change in the repo rate rates, possibly reflecting capital mobility associated with interest rate differentials vis-à-vis other countries. The appreciation of the currency following monetary tightening in turn makes imports cheaper, thereby decreasing the overall price level and the rate of inflation.

\section{While the BPNG has developed and improved its set of monetary instruments} over the years, the instruments could be more effective, to allow the various channels of monetary transmission to operate most effectively. The authorities could consider an in-depth assessment of the financial system to take stock, identify, and address remaining weaknesses in the sector. These include improving governance of the central bank and financial institutions, strengthening the regulatory framework, as well as enhancing the legal framework, with a view to improving the monetary transmission mechanism to the real sector. In addition, strengthening the quality, frequency and timeliness of price statistics and indicators of economic activity would contribute to an improved understanding of the monetary transmission mechanism. 


\section{Annex I. Model Variance Decomposition: Data Evidence}

Table 1. Variance Decomposition of the Basic Model 1/

\begin{tabular}{|c|c|c|c|c|c|c|c|c|c|c|}
\hline \multirow[b]{2}{*}{ Period } & \multicolumn{5}{|c|}{ Variance decomposition of output } & \multicolumn{5}{|c|}{ Variance decomposition of prices } \\
\hline & Std. error & Output & Prices & Repo & NEER & Std. error & Output & Prices & Repo & NEER \\
\hline 1 & 0.001 & 100.000 & 0.000 & 0.000 & 0.000 & 0.002 & 8.476 & 91.524 & 0.000 & 0.000 \\
\hline 2 & 0.001 & 94.706 & 0.680 & 0.282 & 4.333 & 0.004 & 19.110 & 80.121 & 0.197 & 0.572 \\
\hline 3 & 0.002 & 92.105 & 0.889 & 0.388 & 6.618 & 0.005 & 23.021 & 72.429 & 0.694 & 3.856 \\
\hline 4 & 0.002 & 91.082 & 1.065 & 0.459 & 7.395 & 0.007 & 23.307 & 65.579 & 1.779 & 9.335 \\
\hline 5 & 0.002 & 90.749 & 1.335 & 0.538 & 7.379 & 0.008 & 21.937 & 59.926 & 3.662 & 14.475 \\
\hline 6 & 0.002 & 90.555 & 1.759 & 0.654 & 7.032 & 0.010 & 20.131 & 55.560 & 6.356 & 17.953 \\
\hline 7 & 0.002 & 90.292 & 2.343 & 0.827 & 6.539 & 0.011 & 18.349 & 52.146 & 9.726 & 19.779 \\
\hline 8 & 0.003 & 89.882 & 3.064 & 1.073 & 5.981 & 0.012 & 16.702 & 49.325 & 13.578 & 20.394 \\
\hline 9 & 0.003 & 89.282 & 3.897 & 1.412 & 5.409 & 0.014 & 15.206 & 46.866 & 17.709 & 20.219 \\
\hline 10 & 0.003 & 88.462 & 4.818 & 1.863 & 4.857 & 0.015 & 13.856 & 44.649 & 21.939 & 19.556 \\
\hline 11 & 0.003 & 87.405 & 5.800 & 2.445 & 4.350 & 0.016 & 12.651 & 42.619 & 26.117 & 18.614 \\
\hline 12 & 0.003 & 86.112 & 6.820 & 3.168 & 3.899 & 0.017 & 11.586 & 40.751 & 30.125 & 17.538 \\
\hline 18 & 0.004 & 74.820 & 12.519 & 10.397 & 2.264 & 0.022 & 7.625 & 32.552 & 47.801 & 12.023 \\
\hline 24 & 0.006 & 62.403 & 16.009 & 20.038 & 1.550 & 0.024 & 6.200 & 28.561 & 55.433 & 9.806 \\
\hline 30 & 0.007 & 52.650 & 17.607 & 28.614 & 1.129 & 0.025 & 5.748 & 27.001 & 58.041 & 9.210 \\
\hline
\end{tabular}

Source: Fund staff calculations.

1/ Cholesky Ordering: Output - Prices - Repo - NEER.

Table 2. Variance Decomposition of Extended Model - Lending Rate 1/

\begin{tabular}{|c|c|c|c|c|c|c|c|c|c|c|c|c|}
\hline \multirow[b]{2}{*}{ Period } & \multicolumn{6}{|c|}{ Variance decomposition of output } & \multicolumn{6}{|c|}{ Variance decomposition of prices } \\
\hline & Std. error & Output & Prices & Repo & $\begin{array}{r}\text { Lending } \\
\text { rate }\end{array}$ & NEER & Std. error & Output & Prices & Repo & $\begin{array}{r}\text { Lending } \\
\text { rate }\end{array}$ & NEER \\
\hline 1 & 0.001 & 100.000 & 0.000 & 0.000 & 0.000 & 0.000 & 0.003 & 7.880 & 92.120 & 0.000 & 0.000 & 0.000 \\
\hline 2 & 0.001 & 97.580 & 0.277 & 0.687 & 1.006 & 0.451 & 0.004 & 8.630 & 83.921 & 0.448 & 0.001 & 6.999 \\
\hline 3 & 0.002 & 93.853 & 0.786 & 1.639 & 2.640 & 1.083 & 0.005 & 8.126 & 74.391 & 2.326 & 0.018 & 15.139 \\
\hline 4 & 0.002 & 90.020 & 1.418 & 2.523 & 4.393 & 1.646 & 0.006 & 7.092 & 65.755 & 5.964 & 0.044 & 21.146 \\
\hline 5 & 0.002 & 86.571 & 2.113 & 3.246 & 6.018 & 2.052 & 0.007 & 5.939 & 58.281 & 11.102 & 0.062 & 24.615 \\
\hline 6 & 0.002 & 83.626 & 2.840 & 3.820 & 7.420 & 2.293 & 0.008 & 4.866 & 51.855 & 17.192 & 0.067 & 26.020 \\
\hline 7 & 0.002 & 81.151 & 3.585 & 4.289 & 8.582 & 2.392 & 0.009 & 3.953 & 46.348 & 23.651 & 0.059 & 25.989 \\
\hline 8 & 0.003 & 79.056 & 4.342 & 4.700 & 9.519 & 2.383 & 0.010 & 3.218 & 41.649 & 30.009 & 0.048 & 25.076 \\
\hline 9 & 0.003 & 77.245 & 5.107 & 5.093 & 10.256 & 2.298 & 0.011 & 2.648 & 37.661 & 35.957 & 0.041 & 23.693 \\
\hline 10 & 0.003 & 75.629 & 5.877 & 5.502 & 10.825 & 2.167 & 0.012 & 2.216 & 34.290 & 41.335 & 0.043 & 22.116 \\
\hline 11 & 0.003 & 74.133 & 6.650 & 5.953 & 11.251 & 2.012 & 0.013 & 1.894 & 31.447 & 46.086 & 0.057 & 20.516 \\
\hline 12 & 0.003 & 72.696 & 7.423 & 6.470 & 11.560 & 1.851 & 0.014 & 1.658 & 29.050 & 50.220 & 0.083 & 18.988 \\
\hline 18 & 0.004 & 63.422 & 11.749 & 11.752 & 11.850 & 1.227 & 0.019 & 1.159 & 20.686 & 65.172 & 0.394 & 12.589 \\
\hline 24 & 0.005 & 52.271 & 14.762 & 20.814 & 10.916 & 1.237 & 0.022 & 1.165 & 17.395 & 70.946 & 0.723 & 9.771 \\
\hline 30 & 0.006 & 41.741 & 16.174 & 30.898 & 9.794 & 1.393 & 0.023 & 1.244 & 16.015 & 73.206 & 0.933 & 8.603 \\
\hline
\end{tabular}

Source: Fund staff calculations.

1/ Cholesky Ordering: Output - Prices - Repo - Lending rate - NEER 
Table 3. Variance Decomposition of Extended Model - Bank Credit 1/

\begin{tabular}{|c|c|c|c|c|c|c|c|c|c|c|c|c|}
\hline \multirow[b]{2}{*}{ Period } & \multicolumn{6}{|c|}{ Variance decomposition of output } & \multicolumn{6}{|c|}{ Variance decomposition of prices } \\
\hline & Std. error & Output & Prices & Repo & Credit & NEER & Std. error & Output & Prices & Repo & Credit & NEER \\
\hline 1 & 0.001 & 100.000 & 0.000 & 0.000 & 0.000 & 0.000 & 0.003 & 10.864 & 89.136 & 0.000 & 0.000 & 0.000 \\
\hline 2 & 0.001 & 99.186 & 0.179 & 0.032 & 0.479 & 0.124 & 0.004 & 11.371 & 82.927 & 1.270 & 1.628 & 2.804 \\
\hline 3 & 0.001 & 97.691 & 0.515 & 0.077 & 1.470 & 0.248 & 0.005 & 10.390 & 74.461 & 4.890 & 4.483 & 5.775 \\
\hline 4 & 0.002 & 95.729 & 0.969 & 0.131 & 2.837 & 0.334 & 0.006 & 8.838 & 65.479 & 10.261 & 7.590 & 7.831 \\
\hline 5 & 0.002 & 93.436 & 1.520 & 0.201 & 4.458 & 0.385 & 0.007 & 7.256 & 57.044 & 16.365 & 10.355 & 8.980 \\
\hline 6 & 0.002 & 90.909 & 2.154 & 0.297 & 6.232 & 0.408 & 0.008 & 5.878 & 49.661 & 22.424 & 12.550 & 9.487 \\
\hline 7 & 0.002 & 88.227 & 2.860 & 0.429 & 8.075 & 0.410 & 0.009 & 4.760 & 43.448 & 28.029 & 14.163 & 9.600 \\
\hline 8 & 0.003 & 85.449 & 3.627 & 0.607 & 9.920 & 0.398 & 0.010 & 3.884 & 38.321 & 33.036 & 15.271 & 9.489 \\
\hline 9 & 0.003 & 82.621 & 4.444 & 0.843 & 11.716 & 0.376 & 0.011 & 3.207 & 34.122 & 37.440 & 15.970 & 9.261 \\
\hline 10 & 0.003 & 79.775 & 5.302 & 1.146 & 13.427 & 0.349 & 0.012 & 2.686 & 30.685 & 41.297 & 16.352 & 8.979 \\
\hline 11 & 0.003 & 76.936 & 6.190 & 1.528 & 15.026 & 0.320 & 0.013 & 2.285 & 27.866 & 44.680 & 16.490 & 8.678 \\
\hline 12 & 0.003 & 74.118 & 7.099 & 1.997 & 16.495 & 0.291 & 0.014 & 1.975 & 25.543 & 47.662 & 16.443 & 8.377 \\
\hline 18 & 0.004 & 58.110 & 12.485 & 6.887 & 22.317 & 0.201 & 0.019 & 1.116 & 17.799 & 59.958 & 14.243 & 6.884 \\
\hline 24 & 0.005 & 44.334 & 16.671 & 14.871 & 23.819 & 0.306 & 0.022 & 0.901 & 14.997 & 66.544 & 11.607 & 5.952 \\
\hline 30 & 0.006 & 33.524 & 19.040 & 23.827 & 23.101 & 0.507 & 0.023 & 0.846 & 13.944 & 69.300 & 10.513 & 5.396 \\
\hline
\end{tabular}

Source: Fund staff calculations.

1/ Cholesky Ordering: Output - Prices - Repo - Credit - NEER

Table 4. Variance Decomposition of Extended Model - Bank Reserves 1/

\begin{tabular}{|c|c|c|c|c|c|c|c|c|c|c|c|c|}
\hline \multirow[b]{2}{*}{ Period } & \multicolumn{6}{|c|}{ Variance decomposition of output } & \multicolumn{6}{|c|}{ Variance decomposition of prices } \\
\hline & Std. error & Output & Prices & Reserves & Repo & $\overline{\text { NEER }}$ & Std. error & Output & Prices & Reserves & Repo & NEER \\
\hline 1 & 0.001 & 100.000 & 0.000 & 0.000 & 0.000 & 0.000 & 0.003 & 7.321 & 92.679 & 0.000 & 0.000 & 0.000 \\
\hline 2 & 0.001 & 98.174 & 0.222 & 0.273 & 0.149 & 1.182 & 0.004 & 8.046 & 84.375 & 0.074 & 0.379 & 7.126 \\
\hline 3 & 0.002 & 95.833 & 0.615 & 0.658 & 0.294 & 2.601 & 0.005 & 7.568 & 74.530 & 0.058 & 2.336 & 15.508 \\
\hline 4 & 0.002 & 93.802 & 1.102 & 0.999 & 0.395 & 3.702 & 0.006 & 6.608 & 65.583 & 0.063 & 6.143 & 21.603 \\
\hline 5 & 0.002 & 92.231 & 1.650 & 1.260 & 0.469 & 4.389 & 0.007 & 5.551 & 57.938 & 0.123 & 11.377 & 25.011 \\
\hline 6 & 0.002 & 91.044 & 2.244 & 1.451 & 0.538 & 4.723 & 0.008 & 4.571 & 51.471 & 0.267 & 17.394 & 26.297 \\
\hline 7 & 0.002 & 90.116 & 2.876 & 1.591 & 0.621 & 4.796 & 0.009 & 3.737 & 46.003 & 0.496 & 23.602 & 26.162 \\
\hline 8 & 0.002 & 89.327 & 3.542 & 1.698 & 0.737 & 4.696 & 0.010 & 3.063 & 41.381 & 0.794 & 29.574 & 25.187 \\
\hline 9 & 0.003 & 88.581 & 4.240 & 1.786 & 0.905 & 4.488 & 0.011 & 2.536 & 37.479 & 1.137 & 35.061 & 23.788 \\
\hline 10 & 0.003 & 87.802 & 4.963 & 1.865 & 1.146 & 4.223 & 0.012 & 2.133 & 34.185 & 1.500 & 39.953 & 22.229 \\
\hline 11 & 0.003 & 86.934 & 5.706 & 1.943 & 1.482 & 3.935 & 0.013 & 1.830 & 31.403 & 1.865 & 44.233 & 20.669 \\
\hline 12 & 0.003 & 85.936 & 6.463 & 2.023 & 1.932 & 3.646 & 0.014 & 1.606 & 29.049 & 2.220 & 47.933 & 19.192 \\
\hline 18 & 0.004 & 76.457 & 10.793 & 2.682 & 7.700 & 2.368 & 0.018 & 1.118 & 20.655 & 3.884 & 61.325 & 13.018 \\
\hline 24 & 0.005 & 63.059 & 13.719 & 3.601 & 17.775 & 1.847 & 0.021 & 1.121 & 17.155 & 4.809 & 66.702 & 10.213 \\
\hline 30 & 0.006 & 50.505 & 14.997 & 4.516 & 28.356 & 1.628 & 0.022 & 1.189 & 15.604 & 5.285 & 68.926 & 8.996 \\
\hline
\end{tabular}

Source: Fund staff calculations.

1/ Cholesky Ordering: Output - Prices - Reserves - Repo - NEER. 


\section{References}

David, S., and A. Nants, 2006, "Monetary Policy Transmission Mechanisms in Papua New Guinea.” Bank of Papua New Guinea Working Paper, 2006/01 (Papua New Guinea: Bank of Papua New Guinea).

Favero, C. A., 2001, Applied Macroeconometrics, (Oxford: University Press).

Mahadeva L., Sinclair P., 2001, “The transmission mechanism of monetary policy,” paper prepared for the Central Bank Governors' Symposium, Bank of England.

Mayes, D., 2004, "The Monetary Transmission Mechanism in the Baltic States," The Monetary Transmission Mechanism in the Baltic States (Talinn: Bank of Estonia).

Mishkin, S. F., 1996, “The Channels of Monetary Transmission: Lessons for Monetary Policy,” NBER Working Paper, No. 5464 (Cambridge, Massachusetts: National Bureau of Economic Research).

— , 2001, "The Transmission Mechanism and the Role of Asset Prices in Monetary Policy," NBER Working Paper No. 8617 (Cambridge, Massachusetts: National Bureau of Economic Research).

Saxegaard, Magnus, 2006, "Excess Liquidity and the Effectiveness of Monetary Policy: Evidence from Sub-Saharan Africa," IMF Working Paper, No. 06/115 (Washington: International Monetary Fund).

Sims, C., J. Stock, and M. Watson., 1990, "Inference in Linear Time Series Models with Some Unit Roots.” Econometrica 58 (1): 161-82. 


\section{Papua New Guinea: EXPort Performance And Competitiveness ${ }^{1}$}

\section{A. Introduction}

1. Export performance is a key factor driving both economic growth and stability in a small open economy like Papua New Guinea. Accordingly, this paper reviews a broad set of indicators of export competitiveness, including estimation of the equilibrium real effective exchange rate (REER) using different methodologies. The REER appears to be broadly in equilibrium at present. However, other indicators suggest Papua New Guinea faces structural competitiveness problems, including a weak business environment, poor physical and knowledge infrastrucuture, land tenure issues, crime, and weak governance, which hamper overall export competitiveness. Looking forward, Papua New Guinea would benefit from accelerating the structural reforms necessary to improve the investment environment for the nonmineral economy.

2. The remainder of this chapter is structured as follows: Section B reviews Papua New Guinea's export performance over the last decade. Section $\mathrm{C}$ considers different measurements of price competitiveness and Section $\mathrm{D}$ estimates the equilibrium real effective exchange rate. Section E assesses structural competitiveness in Papua New Guinea. Finally, the conclusions are presented in Section F.

\section{B. Export Performance}

3. Since 1995, Papua New Guinea's export performance has been lackluster, notwithstanding large mineral discoveries during the 1980s and early 1990s. Mineral export volumes have generally been on a declining trend reflecting depletion of proven reserves (especially for petroleum) and until recently a lack of new investment in exploration activities. Nonmineral export volumes have increased somewhat, mainly because of increased palm oil acreages, logging, and production of copra oil. Despite this increase, nonmineral export values have

\begin{tabular}{|lccc|}
\hline \multicolumn{4}{|c|}{ Papua New Guinea: Export Values, } \\
(Annual growth)
\end{tabular}
declined significantly because of lower average prices during the review period. Analysis of the causes of this poor export performance is particularly important because growth in Papua New Guinea is closely linked to exports. Indeed, real GDP growth has been generally modest, averaging about 1 percent annually for the period 1995-2006. Some salient developments are summarized below.

\footnotetext{
${ }^{1}$ Prepared by Ebrima Faal, Qaizar Hussain, Agnes Isnawangsih, and Aiko Mineshima. This chapter is based on a presentation delivered at the Bank of Papua New Guinea in Port Moresby in November 2007 and benefits from comments received at that time.
} 
- $\quad$ Export values grew at an average rate of about 5.3 percent for the period 1995-2006. Mineral exports performed somewhat better (growth rate of about 7.3 percent) than nonmineral exports (growth rate of about 3.3 percent).

- $\quad$ The average export growth rates masked very high year-to-year fluctuations in virtually all the products, with an overall coefficient of variation of 18 . At least 95 percent of Papua New Guinea's exports are commodities, with raw minerals accounting for about 80 percent of total exports.

- $\quad$ Both price and volume trends affected the observed trend in values. For the period 1995-2006, average export volumes grew by only about -0.8 percent per annum. Mineral export volumes grew by -1 percent, while nonmineral exports volumes grew by 1 percent. Strong export volume growth was observed mainly in palm oil, and to some extent, in tea, copper and cocoa.

- $\quad$ Mineral exports were negatively affected by declining oil reserves, the closure in 1989 of the large Bougainville copper mine, and the virtual cessation of mining exploration activities and sharp decline in oil sector exploration until the recent up tick in global mining and oil prices. Petroleum export volumes declined by 7.7 percent on average during 1995-2006. This was partially offset by increased production at the Ok Ted copper mine.

- $\quad$ Overall average export prices increased by about 7.2 percent per annum in U.S. dollar terms during 1995-2006. Mineral price trends were generally favorable over the period under study. Average mineral prices increased by 11 percent, while nonmineral prices increased by about 1.5 percent. Prior to 2002, poor price trends were observed virtually across the board with the exception of oil.

4. Papua New Guinea's export growth can be decomposed into three broad factors: global demand, product and markets, and competitiveness.

\section{Global Demand}

- $\quad$ Part of export growth can be attributed to rising international demand; i.e., the stronger global import demand is for a particular product, the stronger would export value growth for that product be. This has been the main influence on export value growth in Papua New Guinea. Rising mineral prices have increased the share of mineral exports in total exports from 70 percent during 1991-99 to 77 percent in 2000-06 despite declining export volumes. 

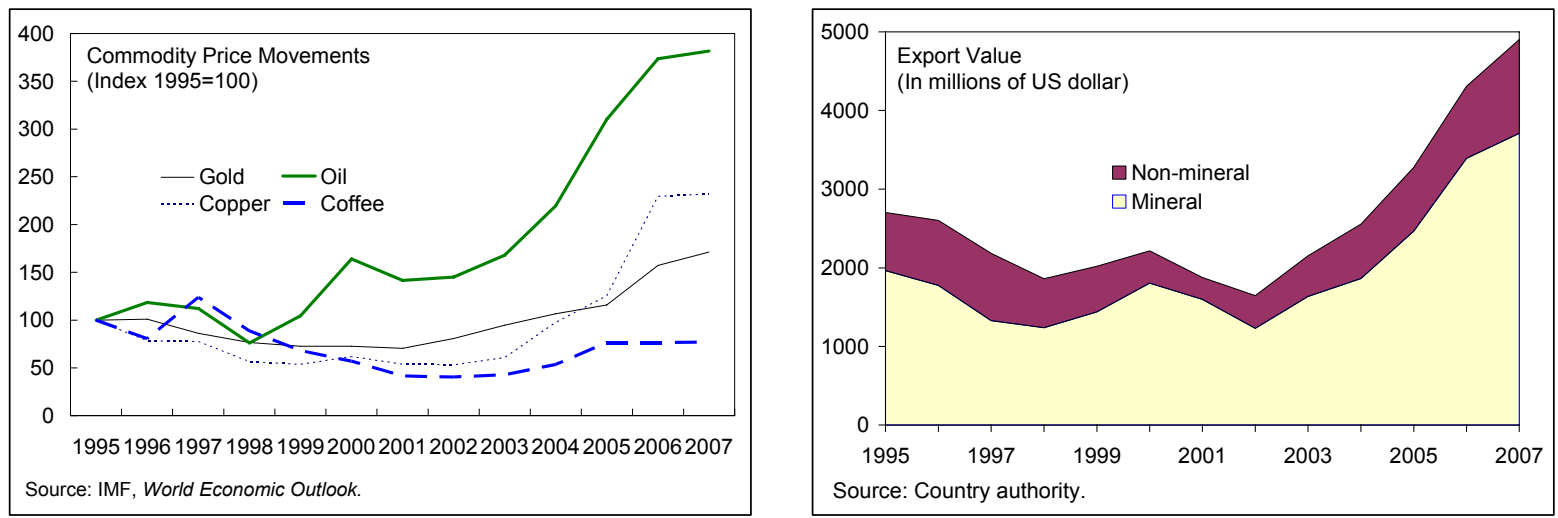

\section{Product and Market}

\section{While Papua New Guinea's share of the world exports market has been} improving in value terms since 2002 with the rise in commodity prices, it has been declining in volume terms over the past decade. Over a longer-term, an increase in market share could be expected if Papua New Guinea's exports mainly comprised products for which world demand is growing more rapidly than the global average. However, against the background of a commodity demand boom, while world trade volumes increased by around 7.1 percent per annum over the period 1995-2006, over the same period, Papua New Guinea's export volume growth averaged around -0.8 percent per annum. As a result, the share of country's goods in world exports has made significant losses since the mid-1995 in volume terms. Although nonmineral export volume has increased recently, the increase has been less than the world's increase.
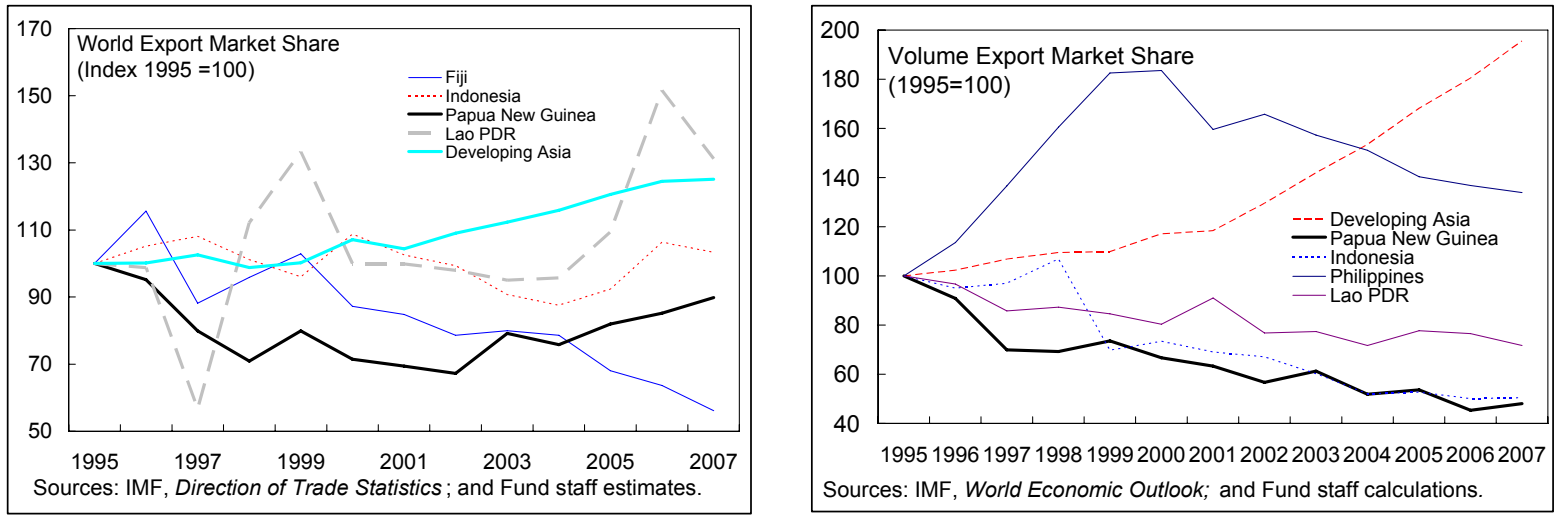
- The range of Papua New Guinea's exports is limited and has been relatively unchanged over the years. Exports consist mainly of commodities, including minerals and fuel, wood products, and agricultural products. Other areas, such as manufactured products, contribute little.

\begin{tabular}{|c|c|c|c|c|c|c|}
\hline \multicolumn{7}{|c|}{$\begin{array}{l}\text { Papua New Guinea: Exports Composition and Growth } \\
\text { (In percent, annual average) }\end{array}$} \\
\hline & \multicolumn{3}{|c|}{ 1991-99 } & \multicolumn{3}{|c|}{$2000-06$} \\
\hline & Share to total & Growth rate & $\begin{array}{r}\text { Contribution } \\
\text { to growth }\end{array}$ & Share to total & Growth rate & $\begin{array}{r}\text { Contribution } \\
\text { to growth }\end{array}$ \\
\hline Total & 100.0 & 20.0 & 100.0 & 100.0 & 14.7 & 100.0 \\
\hline Agricultural products & 29.5 & 21.9 & 1.9 & 22.3 & 7.9 & 24.4 \\
\hline Fuels and mining products & 70.1 & 20.7 & 99.1 & 77.0 & 17.6 & 72.9 \\
\hline Manufactures & 0.5 & 1.4 & -1.0 & 0.8 & 50.0 & 2.6 \\
\hline
\end{tabular}

- Export performance can also be affected by changes in the demand for exports across regions such that an increase in global market share would be expected if a country's exports were destined for markets that grow more rapidly than the global average. However, Australia remains Papua New Guinea's main trading partner-reflecting historical ties, rather than the fast growing emerging economies to the north.

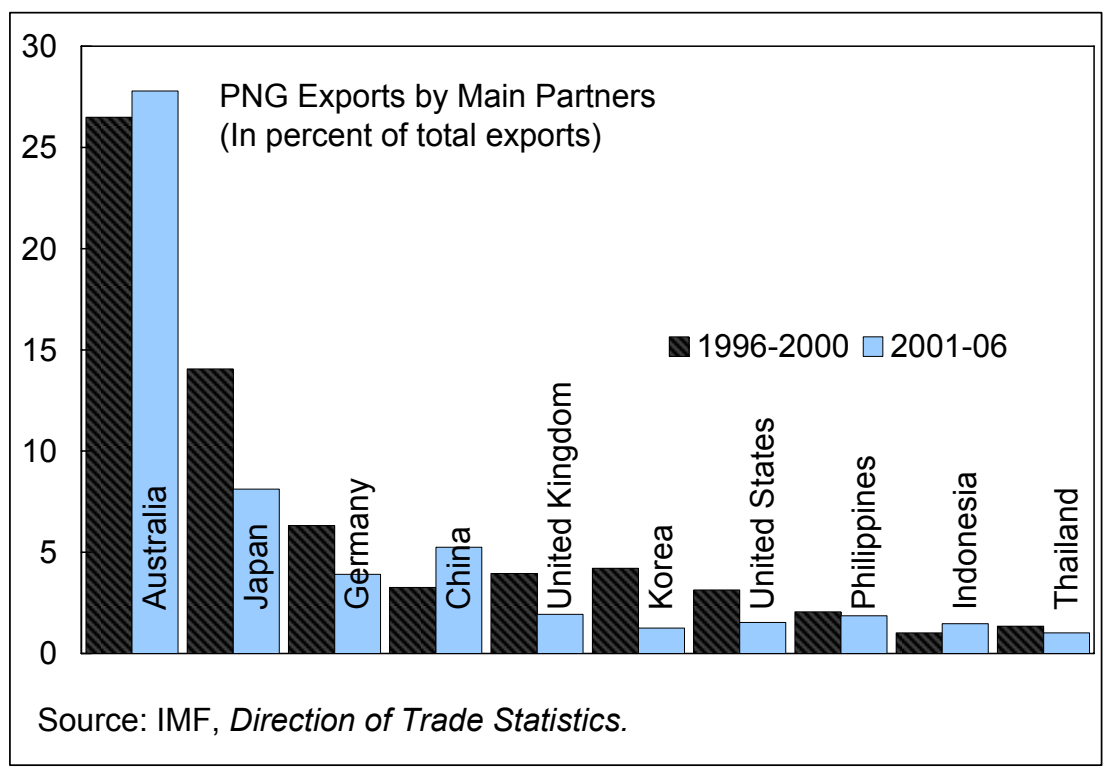




\section{Assessing Competitiveness: Wage and Cost Indicators}

\section{Labor costs}

\section{Wage costs are an important component in the total costs of producing exports;} unfortunately, poor data availability bar a thorough analysis on these grounds in Papua new Guinea. Unit labor costs in the traded sector relative to the main trading partners, expressed in a common currency, are generally accepted as a useful proxy for cost competitiveness. However, the latest data collected for Papua New Guinea dates from the mid-1990s. A study by Duncan and Lawson (1997) found that Papua New Guinea's unit labor costs were high compared to competitor countries, such as Malaysia, Indonesia, and the Philippines. For the period 1970-1994, unit labor costs for Malaysia and the Philippines averaged

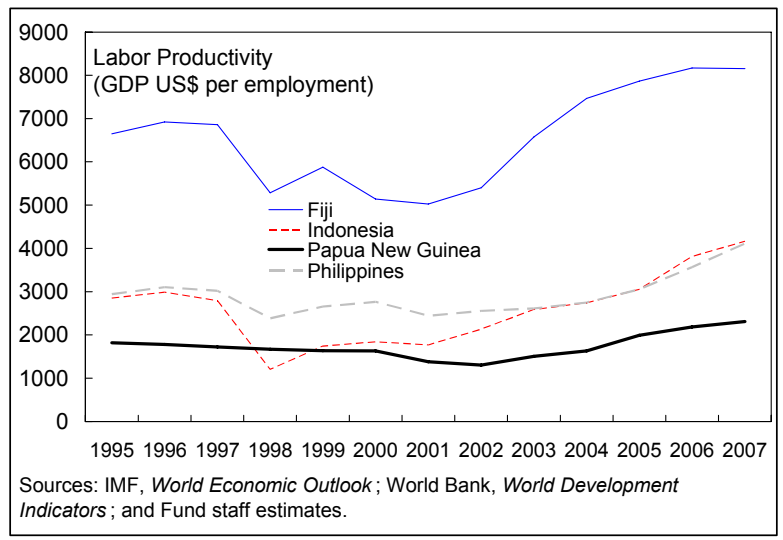
40 percent of those of the United States, and those of the Indonesia averaged 0 percent, ${ }^{2}$ while Papua New Guinea averaged 80-100 percent. Duncan and Lawson show that the main reason for the high unit labor costs in Papua New Guinea was poor productivity performance. Available data since the Duncan and Lawson study was completed suggest there has likely been no improvement in productivity, since the mid-1990s. ${ }^{3}$

\footnotetext{
${ }^{2}$ R. Duncan and T. Lawson. 1997. Cost Structures in Papua New Guinea. Port Moresby: Institute of National. Affairs, Discussion Paper No. 69:45.

${ }^{3}$ Faal (2006) estimates that total factor productivity growth during 1980-2006 was zero.
} 


\section{Real Effective Exchange Rates}

\section{Real effective exchange rate} (REER) indicators suggest that price competitiveness has remained roughly unchanged over the past decade. The REER has remained largely stable since the August 1994 devaluation (depreciation by about 0.37 percent for the period January 1995-July 2007), as appreciation on a nominal effective exchange rate basis was offset by relatively lower domestic inflation.

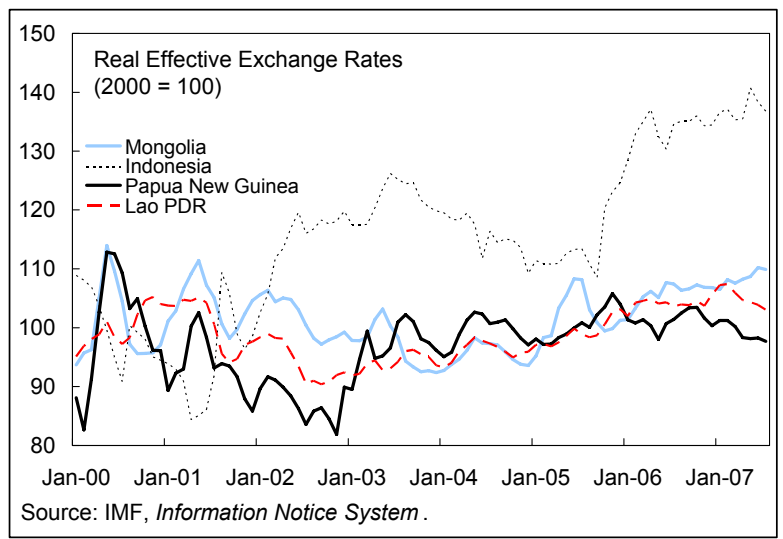

8. Pair wise correlation analysis shows no evidence of an inter-relationship between the REER and export performance in Papua New Guinea. Granger causality tests seem to indicate no causality between exports and the REER. ${ }^{4}$ Nonetheless, it would be premature to conclude that changes in the REER would not affect export performance.

- $\quad$ First, it is likely that the limited impact of the exchange rate on export performance reflects the duality between the mineral sector and the nonmineral sector. The mining industry has largely operated at world prices as an enclave with few linkages to the rest of the economy.

- $\quad$ Second, the results are consistent with the view that export growth has generally been a result of discovery of new minerals and, to some extent, the extension of cultivated areas (e.g., palm oil and copra), rather than the emergence of nontraditional exports. Thus, export volumes would have been little affected by foreign currency-denominated prices (see Mlachila 2002).

9. Other research has found that a real depreciation in Papua New Guinea has a positive impact on the nonmineral sector, for example, by opening up new markets. ${ }^{5}$

\section{Assessing Competitiveness: REER Estimates}

10. This section seeks answers to the question of whether the REER is in line with macroeconomic fundamentals. As estimates of equilibrium real effective exchange rates (EREERs) tend to be quite sensitive to the methodology used, especially in countries like

\footnotetext{
${ }^{4}$ The hypothesis that changes in export values do not Granger-cause changes in the REER is rejected at the 5 percent significance levels. P-values of 0.233 and 0.665 suggests that we cannot reject the hypothesis.

${ }^{5}$ In a detailed study of the tree-crop sector in Papua New Guinea, Kannapiram (2000) argued that kina depreciation achieved the twin objectives of improving competitiveness and increasing profit margins, especially for coffee and oil palm production and exports.
} 
Papua New Guinea with severe data limitations, this study uses three different approaches: the purchasing power parity approach (PPP), the macroeconomic balance approach, and the behavioral equilibrium exchange rate (BEER) approach.

\section{Purchasing Power Parity Approach}

11. Assessing real exchange rate misalignment under the Purchasing Power Parity (PPP) approach involves a comparison of prices of a basket of goods produced by the home country with those of a comparable basket abroad and calculating the exchange rate that would equate them. Assuming the

Balassa-Samuelson hypothesis holds, a country's prices should become relatively higher as the country becomes relatively richer. The real exchange rate calculated on a PPP basis - measured as the ratio of the domestic price level to international prices - is currently below what would be predicted given Papua New Guinea's relative income. However, the deviation is small compared to other countries.

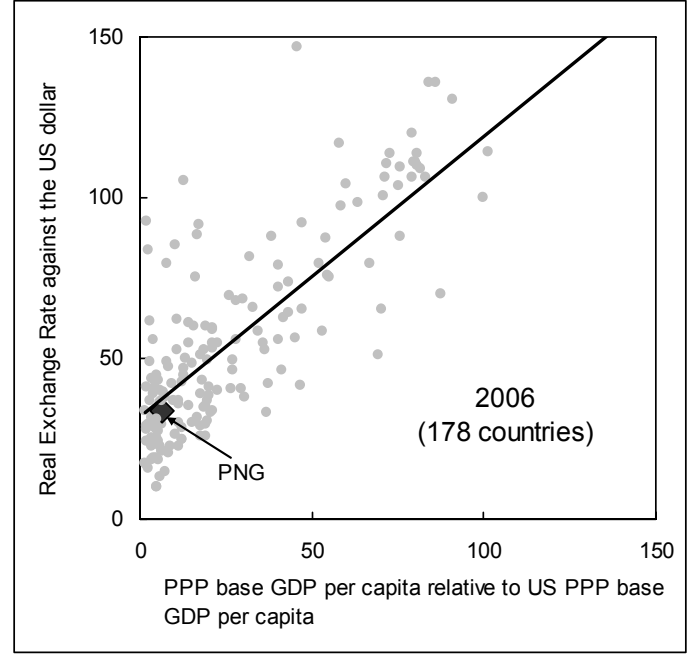

\section{Macroeconomic Balance Approach}

\section{Macroeconomic Balance approach estimates the REER that simultaneously} achieves internal and external balance. To this end, the fundamental equilibrium exchange rate (FEER) is defined as the exchange rate that will equate the current account to the structural savings/investment balance in the medium term. The estimation process comprises the following three steps:

- $\quad$ estimating an equilibrium relationship between current account balances and a set of fundamentals;

- $\quad$ computing an equilibrium current account (current account norm) from these relationships as a function of the levels of fundamentals projected to prevail in the medium term; and

- $\quad$ calculating the REER adjustment that would close the gap between the estimated current account norm and the underlying current account balance (the current account projection for 2012). 
13. The fundamental variables used for the model are the following:

demographic variables affecting the saving rate (old dependency ratio and population growth rate), initial net foreign assets (share of nominal GDP), fiscal balance (share of nominal GDP), relative income (PPP-based per-capita income relative to Australian data), relative real interest rate (relative to Australian data), and mineral exports (share of nominal GDP).

\begin{tabular}{|l|c|}
\hline \multicolumn{2}{|c|}{ Macroeconomic Balance Approach: Current Account Regression } \\
\hline Old-age Dependency & $-4.52^{*}$ \\
Population Growth & $-25.05^{*}$ \\
Initial NFA & $-0.58^{*}$ \\
Fiscal Balance & -0.38 \\
Relative Income & $3.17^{* *}$ \\
Relative Real Interest Rate & -0.25 \\
Mineral Exports & 0.46 ** \\
Constant & 44.23 \\
\hline Adjusted R-squared & 0.85 \\
\hline Note: A * ** indicates significance at the 10,5 percent \\
level.
\end{tabular}

14. Given the estimated import/exports elasticities to exchange rate movements, the REER would need to appreciate by 0.4 percent to close the gap between the underlying current account balance ( -2.5 percent) and the current account norm (3.1 percent). ${ }^{6}$

\section{Behavioral Equilibrium Exchange Rate Approach}

\section{This approach estimates the EREER by identifying structural determinants using} a behavioral exchange rate model. Clark and McDonald (1998, 2000) popularized the behavioral equilibrium exchange rate (BEER) approach as a modeling strategy designed to seek a long run relationship between observed real exchange rates and a set of fundamental determinants derived from a theoretical real exchange rate model. An attractive feature of the model is that the real exchange rate is required to be in equilibrium only in terms of its value given by the appropriate set of explanatory variables over a specific sample period. This allows representation of the equilibrium real exchange rate in terms of the dynamic structure that generates the data on the real exchange rate and its fundamental determinants, even though the variables themselves are derived from a long run structural model. ${ }^{8}$

\footnotetext{
${ }^{6}$ The results should be treated with some caution given the limited data set and degrees of freedom.

${ }^{7}$ Annual data for 1992-2006 are used for the econometric analyses and are shown in Table 1. Elasticity of exports/imports/current accounts with respect to the REER are assumed to be:
}

- $\quad$ Exports: -0.46 (one percent appreciation in REER decreases exports in share of GDP by 0.46).

- Imports: -0.62 (one percent appreciation in REER decreases imports in share of GDP by 0.62).

- Current accounts: $-0.46^{*}$ (exports in share of GDP)-(-0.62)*(imports in share of GDP).

${ }^{8}$ Hinkle \& Montiel, 1999. 
16. The paper uses a vector error correction model to estimate the BEER. The following model is estimated using Johansen's co-integration and error correction techniques. ${ }^{9}$

$$
L R E E R=\beta_{0}+\beta_{1} L T O T+\beta_{2} R I D+\beta_{3} L Y P C+\beta_{4} O P E N+\beta_{5} N F A G D P+\beta_{6} F I S+\beta_{7} D S R+\mu
$$

where the notation used is defined in Box 1. The figure below shows the behavior of the key fundamental variables since 1994. The analysis shows that commodity price movements, productivity, real interest rates differentials vis-à-vis trading-partner countries, the size of the fiscal balance, net foreign assets position, and the debt service ratio explain much of the long-run behavior of the real effective exchange rate.

The results of the estimation are summarized in the table below and show that:

- An increase in the terms of trade of 1 percent is associated with a depreciation of 0.16 percent in the real effective exchange rate.

- An increase in real interest rate differential of one percentage point is associated with an appreciation of 0.01 percent in the real effective exchange rate.

- $\quad$ An increase in real GDP per capita relative to trading partners of 1 percent is associated with an appreciation of 0.10 percent in the real effective exchange rate.

- An improvement in the fiscal balance of 1 percentage point of GDP is associated with an appreciation of the real effective exchange rate of around 1.4 percent.

- An improvement in the debt service ratio of 1 percentage point is associated with an appreciation of the real effective exchange rate of around 0.4 percent.

\footnotetext{
${ }^{9}$ An important advantage over single-equation methods (such as the Engle-Granger method) is that this approach accounts for simultaneity and autocorrelation of the endogenous variables. The VECM also permits the inclusion of additional exogenous variables that may help explain the short-run behavior of the real exchange rate.
} 
Selected Results of the Vector Error Correction Estimates

Sample period: 1995Q2-2006Q4 1/

(1)

(2)

Estimates of the cointegrating relationship with the real exchange rate

\begin{tabular}{|c|c|c|c|}
\hline Log of real exchange rate & $\operatorname{LREER}(-1)$ & 1.000 & 1.000 \\
\hline Log of terms of trade & LTOT(-1) & $\begin{array}{c}0.169 \\
{[5.241]}\end{array}$ & $\begin{array}{c}0.160 \\
{[3.133]}\end{array}$ \\
\hline Real interest differential with partners & $\operatorname{RID}(-1)$ & $\begin{array}{c}-0.007 \\
{[-4.443]}\end{array}$ & $\begin{array}{c}-0.008 \\
{[-3.532]}\end{array}$ \\
\hline Real income per capital relative to partners & LYPC (-1) & $\begin{array}{c}-0.219 \\
{[-5.578]}\end{array}$ & $\begin{array}{c}-0.101 \\
{[-2.071]}\end{array}$ \\
\hline Measure of Openness & OPEN (-1) & $\begin{array}{c}-0.441 \\
{[-5.109]}\end{array}$ & $\begin{array}{l}\cdots \\
\ldots\end{array}$ \\
\hline Log of net foreign assets to GDP & LNFAGDP $(-1)$ & $\begin{array}{c}-0.033 \\
{[-3.110]}\end{array}$ & $\begin{array}{l}\ldots \\
\ldots\end{array}$ \\
\hline Fiscal deficit to GDP & FIS $(-1)$ & $\begin{array}{c}-1.115 \\
{[-6.292]}\end{array}$ & $\begin{array}{c}-1.434 \\
{[-5.520]}\end{array}$ \\
\hline Debt service ratio & $\operatorname{DSR}(-1)$ & $\begin{array}{c}0.943 \\
{[8.141]}\end{array}$ & $\begin{array}{c}-0.356 \\
{[-2.312]}\end{array}$ \\
\hline C & & -5.155 & -5.089 \\
\hline \multicolumn{4}{|c|}{ Estimates of the Short-term impact on the real exchange rate $D(L R E E R S)$} \\
\hline $\mathrm{D}(\mathrm{RID})$ & & $\begin{array}{c}-0.004 \\
{[-1.957]}\end{array}$ & $\begin{array}{l}\ldots \\
\ldots\end{array}$ \\
\hline $\mathrm{D}(\mathrm{DSR}(-1))$ & & $\begin{array}{c}-0.524 \\
{[-2.217]}\end{array}$ & $\begin{array}{c}-0.610 \\
{[-2.841]}\end{array}$ \\
\hline \multicolumn{4}{|c|}{ Estimates of the speed of adjustment of the real exchange rate: } \\
\hline CointEq1 & & $\begin{array}{c}-0.585 \\
{[-3.487]}\end{array}$ & $\begin{array}{c}-0.356 \\
{[-2.312]}\end{array}$ \\
\hline $\begin{array}{l}\text { Half-life of the deviation from equilibrium exc } \\
\text { in quarters } \\
\text { in years }\end{array}$ & te $2 /$ & $\begin{array}{l}0.85 \\
0.21\end{array}$ & $\begin{array}{l}1.41 \\
0.35\end{array}$ \\
\hline
\end{tabular}

$1 / \mathrm{t}$-statistics in square brackets.

2/ The implied half-life of the shock to real exchange rate is calculated as follows: the time (T) required to dissipate $x$ percent (in this case, 50 percent) of a shock is determined according to $T=(1-x) / \Theta$, where $\Theta$ is the coefficient of the error-correction term and $\mathrm{T}$ is the required number of periods (quarters). 


\section{Box 1. Macroeconomic Determinants of the Exchange Rate}

- $\quad$ Terms of trade (LTOT): The impact of the terms of trade on the real exchange rate is theoretically ambiguous. ${ }^{1}$ Changes in terms of trade entail changes in domestic prices of importables, and as a result, generate inter-temporal and intra-temporal substitution effects as well as income effects. This makes the net effect on the equilibrium real exchange rate (ERER) ambiguous (Edwards 1989, 1994).

- $\quad$ The real interest rate (RID): An increase in a country's real interest rate relative to its trading partners tends to appreciate the ERER. For an economy that is highly open to international capital markets, a higher domestic real interest relative to that of its trading partners creates opportunities for capital inflows.

- $\quad$ Productivity growth differential (LYPD): An increase in productivity relative to other countries leads to an improvement in the current account, thereby appreciating the real exchange rate. Given lack of data availability in Papua New Guinea, we employ real GDP per capita with respect to trading partner countries as a proxy for the Balassa-Samuelson effect.

- $\quad$ Trade policy (Open). Permanently higher levels of trade taxes (i.e., reducing the openness of the economy) lead to ERER appreciation. Consumption becomes more expensive with the increase in the relative price of importables, while also creating excess demand of both exportables and nontraded goods. The excess demand in the nontradable goods sector permits an appreciation of the ERER.

- $\quad$ Net capital inflows (LNFAGDP). Net capital inflows (as a percentage of GDP) are used as a proxy for capital controls. In models of ERER determination, a permanent increase in net capital inflows (interpreted as a reduction in the tax on foreign borrowing) leads to an appreciation of the ERER.

- $\quad$ Fiscal policy (FIS): Fiscal policy has an ambiguous effect on the equilibrium real exchange rate: the direction of its quantitative influence depends on the sectoral composition of the change in government expenditure.

- The debt service ratio (DSR). If the debt service ratio falls permanently, this will improve the sustainability of the current account and thus lead to an appreciation of the ERER. If a country is a net debtor, an increase in the debt burden will deteriorate its current account. The real exchange rate will depreciate and make correction of current account imbalances possible. If a country is a net creditor, higher interest income from loans will lead to a current account surplus and the real exchange rate will appreciate.

$\overline{1 / \text { See MacDonald and Ricci (2003). }}$ 
17. The level of the exchange rate appears to be in line with fundamentals. The equilibrium real exchange rate (ERER) was obtained by imposing the coefficients of the long-run equation on the permanent values of the fundamentals using Hodrick-Prescott (HP) and Christiano-Fitzerald (CF) filters.

- $\quad$ Relative to its equilibrium values (HP and $\mathrm{CF}$ ), the actual exchange rate was mostly undervalued by a small margin during 1994-2007. There were three periods of significant undervaluation during 1995, 1998-2000, and 2001-02, and three brief periods of small to moderate overvaluation in 1997, 2000, and 2005.

- $\quad$ The first resulted from the use of a nominal exchange rate anchor that was not supported by a consistent fiscal policy in the period prior to 1994. It also reflected broad inconsistencies in the conduct of macroeconomic policies and in the fundamental variables.

- $\quad$ By end-2006, the actual RER was somewhat more depreciated than the estimated equilibrium exchange rate. The increase in the ERER is due to various factors. The increase in the terms of trade contributed to kina depreciation as income effects dominated substitution effects. However, the improvement in the fiscal balance, increase in net foreign assets, and small increase in the real interest rate differential partly offset these terms of trade effects.

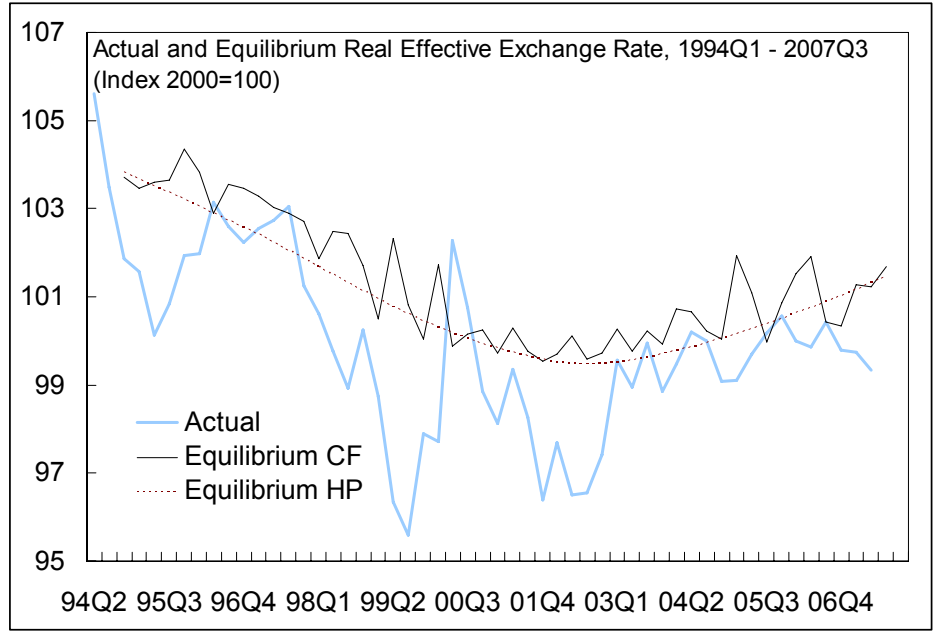




\section{E. Assessing Competitiveness: Structural Indicators}

18. While it appears that price competitiveness is broadly appropriate in Papua New Guinea, structural factors are also important determinants of competitiveness. The structural factors include the business environment (including entrepreneurship, tax regime, regulations, access to finance, and governance), physical and knowledge infrastructure, law and order, land policy, and trade policy. These elements are important determinants of current and future productivity, which is one of the factors that influence competitiveness. One indication of Papua New Guinea's relative structural competitiveness is the comparatively low level of foreign direct investment relative to other resource rich countries in Asia and low income countries globally. Foreign direct investment is particularly low outside of the mineral sector.
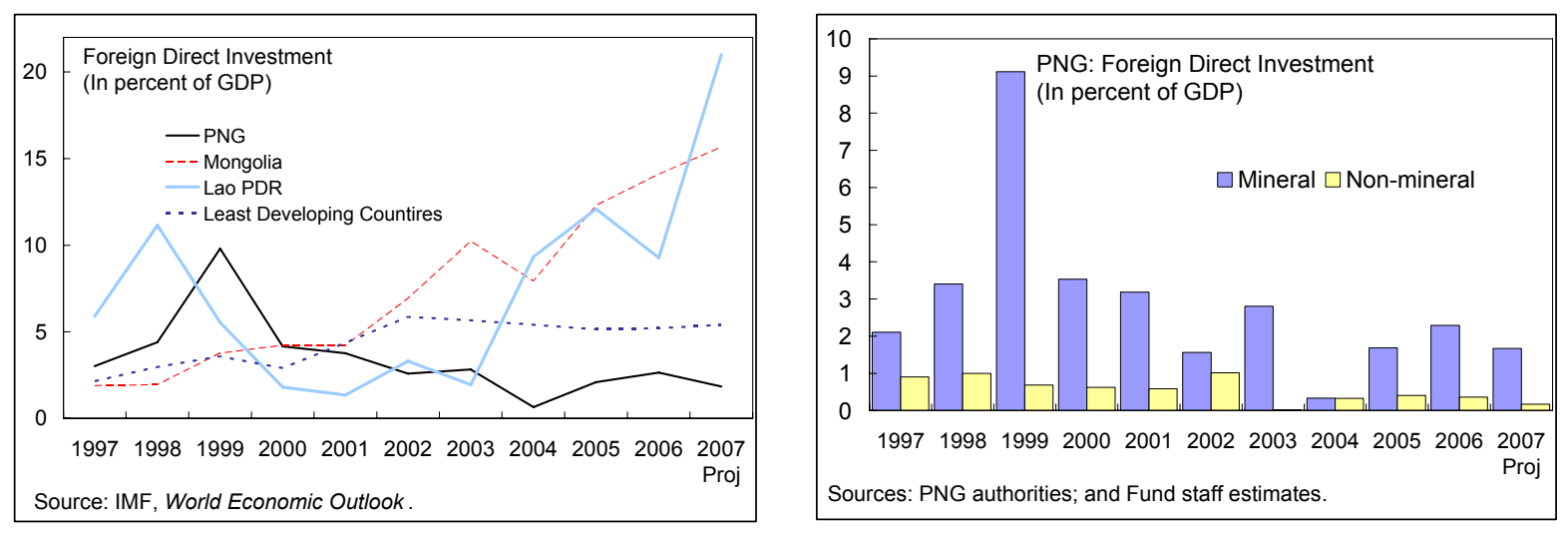

\section{Survey-based indicators of the business environment suggest structural}

impediments to external competitiveness exist. Although Papua New Guinea's ranking in the World Bank's ease-of-doing-business database compares relatively favorably with other countries in the region, key areas rank poorly. These include enforcing contracts, dealing with licenses, getting credit, and trading across borders. Another disincentive to investment is high political risks due to corruption, bureaucracy quality, and ethnic tensions. The World Bank's CPIA index and Transparency International both rank Papua New Guinea poorly on these issues. ${ }^{10}$ In addition, the evolution of rankings indicates that the structural reforms undertaken to date have yet to improve competitiveness in a meaningful way.

\footnotetext{
${ }^{10}$ International comparisons of structural indicators are often based on survey evidence and, therefore, need to be interpreted with caution.
} 
Selected Countries: Doing Business 2006-07 1/

\begin{tabular}{lrrrrrr}
\hline & Fiji & Mongolia & $\begin{array}{c}\text { Papua New } \\
\text { Guinea }\end{array}$ & Philippines & Indonesia & Lao PDR \\
\hline Doing business & 36 & 52 & 84 & 133 & 123 & 164 \\
Starting a business & 69 & 62 & 76 & 144 & 168 & 49 \\
Dealing with licenses & 28 & 43 & 118 & 77 & 99 & 111 \\
Employing workers & 16 & 64 & 31 & 122 & 153 & 82 \\
Registering property & 77 & 18 & 64 & 86 & 121 & 149 \\
Getting credit & 48 & 68 & 115 & 97 & 68 & 170 \\
Protecting investors & 33 & 19 & 33 & 141 & 51 & 176 \\
Paying taxes & 52 & 90 & 79 & 126 & 110 & 114 \\
Trading across borders & 111 & 168 & 82 & 57 & 41 & 158 \\
Enforcing contracts & 62 & 27 & 162 & 113 & 141 & 111 \\
Closing a business & 114 & 115 & 97 & 147 & 136 & 178 \\
\hline
\end{tabular}

1/ Economies are ranked on their ease of doing business, from 1-178, with first place being the best.

Source: World Bank, Doing Business, 2008.

Corruption Perception Index, 2006

\begin{tabular}{lcccc}
\hline & Rank 1/ & CPI Score 2/ & Confidence range 3/ & Surveys used 4/ \\
\hline Sri Lanka & 84 & 3.1 & $2.7-3.5$ & 6 \\
Laos & 111 & 2.6 & $2.0-3.1$ & 4 \\
Phillipines & 121 & 2.5 & $2.3-2.8$ & 9 \\
Indonesia & 130 & 2.4 & $2.2-2.6$ & 10 \\
Papua New Guinea & 130 & 2.4 & $2.3-2.6$ & 4 \\
\hline
\end{tabular}

Source: Transparancy International, 2006.

1/ From 1 to 163 with first place being the best.

2/ Relates to perceptions of the degree of corruption as seen by business people and country analysts, and ranges between 10 (highly clean) and 0 (highly corrupt).

$3 /$ Nominally, with 5 percent probability the score is above this range and with another 5 percent it is below. However, particularly when only few sources are available, an unbiased estimate of the mean coverage probability is lower than the nominal value of $90 \%$.

4/ Twelve surveys and expert assessments were used and at least three were required for a country to be included in the $\mathrm{CPI}$.

APD Resource-rich Low-income Countries: Governance Indicators 1/

\begin{tabular}{|c|c|c|c|c|c|c|}
\hline & Lao P.D.R & Mongolia & $\begin{array}{c}\text { Papua } \\
\text { New Guinea }\end{array}$ & Timor-Leste & Vietnam & Asia average $2 /$ \\
\hline Country Policy and Institutional Assessment (CPIA) & 3.5 & 2.5 & 1.5 & n.a. & 3.5 & n.a. \\
\hline Government effectiveness & -1.1 & -0.4 & -1.0 & -1.0 & -0.3 & 0.6 \\
\hline Rule of law & -1.1 & -0.3 & -0.9 & -0.5 & -0.4 & 0.3 \\
\hline Political stability & -0.3 & 0.9 & -0.8 & -0.7 & 0.3 & -0.2 \\
\hline
\end{tabular}

Sources: World Bank, Kaufamm, Krayy and Mastruzzi (2005).

1/ The World Bank Country Policy and Institutional Assessment rates eligible countries against 16 criteria grouped in four clusters: (a) economic management; (b) structural policies; (c) policies for social inclusion and equity; and (d) public sector management and institutions. Scores range from 1-6, with higher scores reflecting better performance. Other indicators range between \pm 2.5 , with higher positive outcomes reflecting better outcomes. See www.worldbank.org.

2/ Coverage varies depending on data availability. 
20. Papua New Guinea suffers from infrastructure bottlenecks, even when compared to other low income countries. Due to its mountainous terrain, most of the country is impassable, as evidenced by its low proportion of paved roads (less than 5 percent). Access to telecommunications is limited and unit costs are high. At the same time, Papua New Guinea also has low social indicators, indicating a weak knowledge infrastructure. Given the very high annual population growth rate, the country faces considerable challenges in education, especially to increase its school enrolment and retention ratios. In the health sector, a key challenge is to increase access to primary health care facilities, and to reduce the prevalence of communicable diseases.

APD Resource-rich Low-income Countries: Indicators of Human and Physical Capital

\begin{tabular}{|c|c|c|c|c|c|c|}
\hline & Lao P.D.R & Mongolia & $\begin{array}{c}\text { Papua } \\
\text { New Guinea }\end{array}$ & Timor-Leste & Vietnam & Asia average \\
\hline \multicolumn{7}{|l|}{ Public infrastructure quality (most recent year) } \\
\hline Paved roads (percent of total roads) & 14.1 & 3.5 & 3.5 & Poor & 25.1 & 58.0 \\
\hline Water quality (percent of population with access) & 30.0 & 59.0 & 44.0 & 36.0 & 61.0 & 58.3 \\
\hline \multicolumn{7}{|l|}{ Human capital quality Index } \\
\hline Adult literacy rate (percent of ages 15 and over) & 68.7 & 97.8 & 57.3 & 58.6 & 90.3 & 87.9 \\
\hline Life expectancy at birth (years) & 55.1 & 64.5 & 55.7 & 56.0 & 70.8 & 72.1 \\
\hline
\end{tabular}

Source: World Bank, World Development Indicators.

21. Papua New Guinea's law and order problems and related security costs also have an adverse impact on the business environment. In addition to direct costs of security, estimated at 3 percent of total business cost on average, there are indirect costs. Security concerns constrain the geographical area in which a company can operate. Overall labor costs are increased to compensate employees for the added personal insecurity, especially for imported labor. Security concerns also generally lead to reduced intensity of capital equipment usage as during certain hours, for example, at night. Finally, security issues occupy management's time, thereby reducing overall productivity.

22. The lack of transferable land titles is considered another structural impediment, with about 97 percent of the land communally owned. Arguments for land reform include: the traditional tenure system reduces the incentive for landholders to invest in their land since the cost of improvement is privately borne by the landholder while the benefits are socialized; the inability to use land as collateral makes it difficult for landholders to borrow money to finance new investments; and the lack of well-defined property rights over land can divert resources into activities focused on rent-seeking rather than wealth creation. Efforts to modernize land tenure by establishing a national land registry system have met with little success to date due to popular opposition, although there have been some successful individual ventures. For example, in some oil palm estates clearly demonstrable benefits (e.g., royalties, jobs, social services) have encouraged some tribes to lease their land, contributing to a considerable increase in the exports of palm oil.

23. Given its high level of trade openness, Papua New Guinea appropriately maintains one of the least restrictive trade regimes in the region. It fares well relative to comparator countries in terms of both the trade restrictiveness index as well as average import tariffs, 
which are little over 5 percent, following a recently completed tariff reform. ${ }^{11}$ The government is currently conducting an overall review of its trade policy.
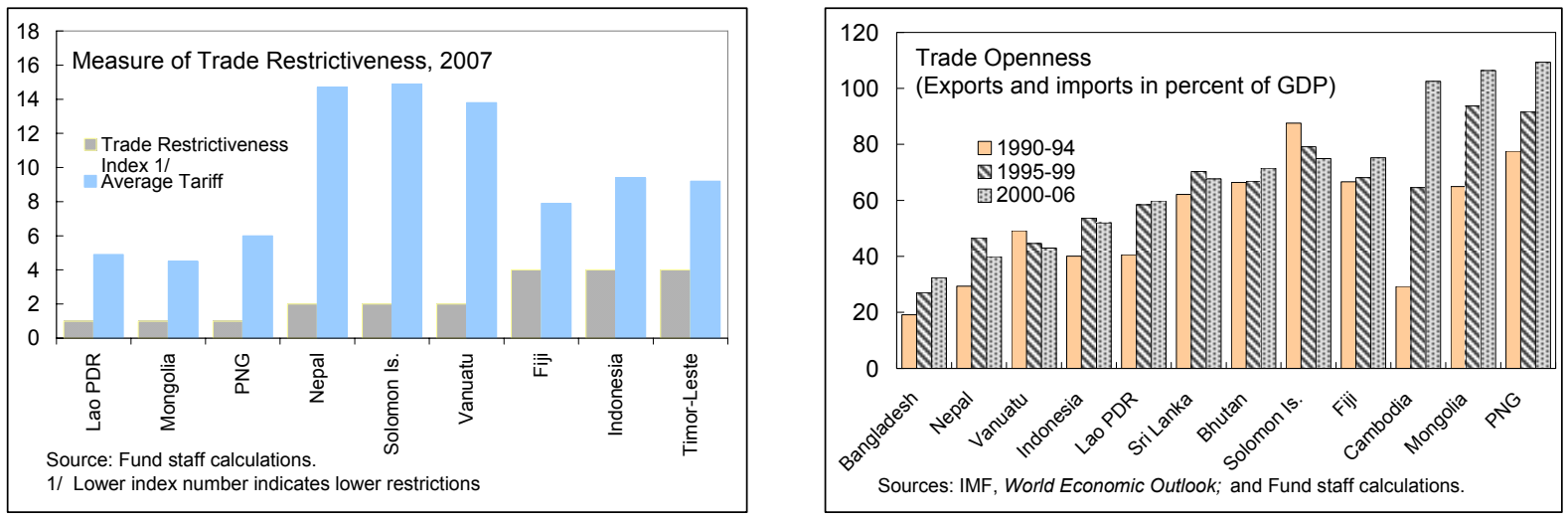

\section{F. Conclusions and Policy Implications}

24. While Papua New Guinea has enjoyed strengthened export performance in recent years, the improvement mainly reflects the significant rise in world commodity prices as exports remain concentrated in the mining and petroleum sectors. In volume terms, Papua New Guinea has seen a declining share in total global trade. Staff estimates indicate that the exchange rate is broadly in line with macroeconomic fundamentals at present. In contrast, comparisons of unit labor costs across countries suggest a cost competitiveness problem, though data availability limits a more thorough analysis and makes comparisons difficult. Available data also indicate a structural competitiveness problem.

\section{Given volatility and scarcity of resources in the mineral sector, sustained} improvement requires enhanced productivity growth and resource reallocation to the nonmineral sector. Foreign direct investment and domestic private investment are key to achieving the necessary economic transformation, but boosting investment will depend on the successful implementation of structural reforms aimed at improving the overall investment environment.

\footnotetext{
${ }^{11}$ There are four major ad valorem tariff rates $(0,15,25,40)$ and some additional specific tariff rates (such as 70 percent on sugar and 20 percent on mackerel).
} 


\section{References}

Balassa, B., 1964, "The Purchasing-Power Parity Doctrine: A Reappraisal," Journal of Political Economy, Vol. 72.

Chen, Y., and K. Rogoff, 2002, "Commodity Currencies and Empirical Exchange Rate Puzzles,” IMF Working Paper No. 02/27 (Washington: International Monetary Fund).

Clark, P., and R. Mac Donald, 2000, "Filtering the BEER: A Permanent and Transitory Decomposition,” IMF Working Paper No. 00/144 (Washington: International Monetary Fund).

Dickey, D., and W. Fuller, 1981, "Likelihood Ratio Statistics for Autoregressive Time Series with a Unit Root," Econometrica, Vol. 49.

Duncan, R., and T. Lawson, 1997, “Cost structures in Papua New Guinea”, Discussion Paper No. 69, Institute of National Affairs, Port Moresby.

Edwards, S., 1989, Real Exchange Rates, Devaluation and Adjustment: Exchange RatePolicies in Developing Countries (Cambridge, Massachusetts: MIT Press).

__ 1994, "Real and Monetary Determinants of Real Exchange Rate Behavior: Theory and Evidence from Developing Countries," in Estimating Equilibrium Exchange Rates, edited by J. Williamson (Washington: Institute for International Economics).

Engle, R. F., and C. Granger, 1987, "Co-integration and Error Correction: Representation, Estimation and Testing," Econometrica, Vol. 55.

Faal, E., 2006, “Growth and Productivity in Papua New Guinea,” IMF Working Paper No. 06/113, (Washington: International Monetary Fund).

Hinkle, L., and P. Montiel, (eds), 1999, Exchange Rate Misalignment, Concept and Measurement for Developing Countries. (London: Oxford University Press).

Kannapiran, C., 2000, Commodity Price Stabilisation: Macroeconomic Impacts and Policy Options, Agricultural Economics 23 (1), 17-30.

Mlachila, M, 2002, Selected Issues and Statistical Index, International Monetary Fund, Papua New Guinea.

MacDonald, R, and Ricci, L, 2003, "Estimation of the Equilibrium Real Exchange Rate for South Africa," IMF Working Paper No. WP/03/44, (Washington: International Monetary Fund). 


\section{Technical Appendix}

\section{Johansen Vector Error Correction}

In order to investigate the existence of a long-run, co-integrating, relationship between the real effective exchange rate and the variables discussed above, our study employs the Johansen (1995) maximum likelihood estimator, which corrects for autocorrelation and endogeneity parametrically using a vector error-correction mechanism (VECM) specification. ${ }^{12}$

The Johansen methodology can be described as follows. Define a vector:

$$
X_{t}=[L R E E R, L T O T, R I D, L Y P C, \text { OPEN }, \text { Kflow, FIS }, D S R]
$$

and assume that the vector has a VAR representation of the form:

$$
x_{t}=\eta+\sum_{i=1}^{p} \prod x_{t-1}+\varepsilon_{t}
$$

where $\eta$ is a ( $\mathrm{n} \times 1)$ vector of deterministic variables, $\mathrm{p}$ is the lag length, and $\varepsilon$ is a $(\mathrm{n} \times 1)$ vector of white noise disturbances, with mean zero and covariance matrix $\Xi$, and $\Pi$ is a $(\mathrm{n} x \mathrm{n})$ matrix of coefficients. Express 3 may be reparameterized into the so-called vector error correction mechanism (VECM) as:

$$
\Delta x_{t}=\eta+\sum_{i=1}^{p-1}+\Phi \Delta x_{t-i}+\prod x_{t-1}+\varepsilon_{t}
$$

where $\Delta$ denotes the first difference operator, $\Phi$ is a ( $\mathrm{n} \times \mathrm{n})$ a coefficient matrix $-\sum_{j=1+i}^{p} \prod_{j}$, and $\Pi$ is a (n x n) matrix equal to $-\sum_{i=1}^{p} \Pi_{j}-I$ whose rank determines the number of co-integrating vectors. When specified in this VECM form, a vector autoregressive process has the advantage of providing information on both the long run relationships among the variables and their short run adjustment to such long run equilibrium relationships.

\footnotetext{
${ }^{12}$ There are alternative ways of addressing serial correlation and endogeneity in a co-integrating framework, such as Phillips and Hansen (1990).
} 
- If $\Pi$ is of full rank, $n$, or zero rank, $\Pi=0$, no co-integration exists amongst the elements in long-run relationship (in these instances it would be appropriate to estimate the model in, respectively, levels or first differences).

- $\quad$ If, $\Pi$ is of reduced rank, $r$ (where $r<n$ ), then there exist ( $\mathrm{x}$ r) matrices $\alpha$ and $\beta$ such that $\Pi=\alpha \beta^{\prime}$, where $\beta$ is the matrix whose columns are the linearly independent co-integrating vectors, and the $\alpha$ matrix is interpreted as the adjustment matrix, indicating the speed with which the system responds to last period's deviations from the co-integrating relationships.

Testing for co-integration therefore requires an estimate of the pie matrix $\Pi=\alpha \beta^{\prime}$. In the Johansen's approach, this is achieved by estimating the pie matrix $\Pi=\alpha \beta^{\prime}$ from the unrestricted VAR model, and then testing whether the restrictions imposed $\Pi$ by the reduced rank of matrix can be rejected by the data. ${ }^{13}$ This is tested using two types of tests advocated by Johansen. The first is the trace statistic, which allows one to perform a log likelihood ratio (LR) test for the null hypothesis that there exist $r$ co-integrating vectors against the alternative of co-integrating vectors (where is the number of endogenous variables in the VAR).

The second is the maximum eigenvalue $(\max -\lambda)$ statistic. This is a log likelihood test that tests the null hypothesis that there is $r$ co-integrating vectors against the alternative that there is co-integrating vectors. Asymptotic critical values for conducting these two tests have been provided by Johansen (1988), and also Osterwald-Lenum (1992).

An important advantage of the Johansen methodology in the current application is that the estimated coefficient - the $p$ vector - can be used to prove a measure of the equilibrium real exchange rate and therefore a quantification of the gap between the prevailing real exchange rate and its equilibrium level. The methodology also derives estimates of the speed at which the real exchange rate converges to the equilibrium level.

13 (Eviews 5.0 Users Guide, p. 724.) 


\title{
IV. Financial Sector Developments in Papua New Guinea ${ }^{1}$
}

\begin{abstract}
A. Introduction
1. In recent years, Papua New Guinea's financial system has experienced rapid transformation helped by sustained economic recovery, low interest rates, and high commodity prices of key exports. Following a period of severe economic and financial crisis in the late 1990s, the authorities began to introduce a significant reform of the financial system in 2000, including an increasingly prudent regulatory and supervisory regime, which has provided a viable environment for the financial sector to grow. This paper takes a snap shot look at the current status of the financial system, including its structure, the regulatory and supervisory framework, performance (using CAMEL approach), as well as the constraints and risks. In the last section, we conduct stress tests on the banking sector to assess its ability to absorb shocks. Finally, we discuss implication of our findings and areas of further reform.
\end{abstract}

\section{B. Overview of the Financial Sector and Recent Developments}

\section{Papua New Guinea's financial sector comprises four commercial banks, a number of finance companies, saving and loan institutions, superannuation funds, insurance companies, a government bond market and a stock exchange.}

3. The banking system has four commercial banks (Australia and New Zealand Bank, Bank South Pacific, Maybank, and Westpac Bank). The domestic bank (Bank South Pacific) is the largest bank accounting for over 50 percent of the banking system. Total assets of the banking system have grown from 36 percent of GDP in 2000 to 51 percent of GDP at end-June 2007. Bank concentration estimated by the Herfindahl index (defined as the sum of squares of the shares of banks) shows a figure of over 40 percent having risen from 25 percent in 2000 following consolidation of the banking system. ${ }^{2}$ Papua New Guinea's banks occupy a large share of the financial system (70 percent). However, despite the banking sector's rapid growth in recent years, access to financial services remains poor, especially in rural areas. There is also a development bank (National Development Bank, formerly the Rural Development Bank) that lends with funds provided by the government.

\footnotetext{
${ }^{1}$ Prepared by Qaizar Hussain. This chapter is based on a presentation delivered at the Bank of Papua New Guinea in Port Moresby in November 2007 and benefits from comments received at that time.

${ }^{2}$ Bank South Pacific has about 40 branches in Papua New Guinea (along with a branch in Niue and newly acquired banks in Fiji and Solomon Islands). The Australian bank subsidiaries, Australia and New Zealand Bank and Westpac Bank, have 9 and 15 branches, respectively, and Maybank, a subsidiary of a Malaysian bank, operates 2 branches in Papua New Guinea (see Briggs, 2007). Along with the branches, the number of Automatic Teller Machines continues to grow rapidly.
} 
4. The nonbank sector has grown significantly. The main institutions include ten licensed finance companies ${ }^{3}$ (including microfinance companies) and seven superannuation funds. ${ }^{4}$ The superannuation funds have enjoyed rapid growth following their restructuring in the early 2000s. At end-2006, total assets of these funds amounted to K2.8 billion (one fourth of total financial sector assets or 16 percent of GDP). The two largest funds, Nambawan Super (formerly Public Officers' Superannuation Fund (POSF)) at 56 percent and Nasfund at 31 percent share of the total, dominate the superannuation industry with 88,000 and 95,000 members, respectively. Prior to its reform in the early 2000s, POSF membership was restricted to government employees but is now opened to the private sector. There are also a number of small saving and loan institutions and insurance companies.

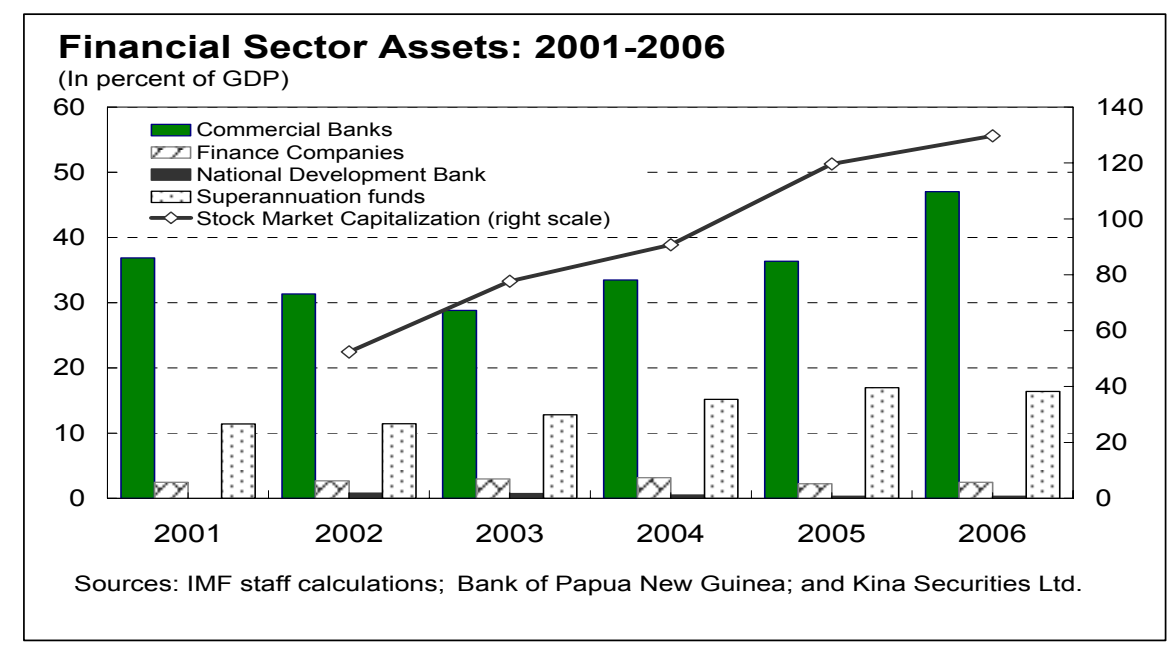

5. The securities market comprises a large government primary bond market and a stock exchange. The government bond market consists of short-term treasury bills and longer-term inscribed bonds (18 percent of GDP). Under the new government debt strategy, the short term instruments are being replaced by instruments with longer maturities in order to deepen the market. These securities are primarily held by commercial banks and other nonbanks. The Port Moresby Stock Exchange (POMSoX) is fairly thin having a share listing of only 14 companies $^{5}$ which have relatively high shareholder concentration; however, market capitalization has jumped from 52 percent of GDP to almost 130 percent of GDP during 2002-06, and has continued to rise sharply in 2007 helped by a positive economic environment and high profits of mining companies. The corporate bond market is virtually nonexistent.

\footnotetext{
${ }^{3}$ These financial institutions are restricted from issuing checkable deposits.

${ }^{4}$ In a superannuation fund, members' entitlements are calculated by reference to the amounts standing in the members' individual accounts and not by reference to defined or guaranteed benefits. It provides for compulsory savings for retirement through mandatory and/or voluntary contributions by employees and employers.

${ }^{5}$ Of the 14 companies, nine have home listings and five have dual listings. Companies comprise mainly mining and financial companies. In addition, there is one company having a debt listing.
} 


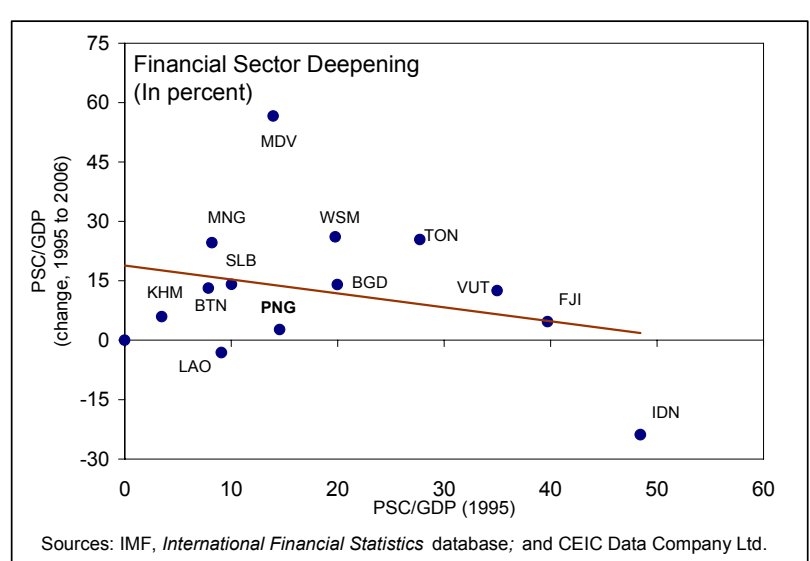

\section{Despite rapid growth of the} banking sector, financial sector depth is still low relative to comparator economies. While private sector credit growth has been high recently in Papua New Guinea, the ratio of credit to GDP is still low. To further estimate financial deepening, we included a sample of comparator Asian economies to examine the relationship between the level of private sector credit to GDP and its change over the last decade. We find that the degree of deepening in Papua New Guinea is low relative to comparators (ceteris paribus we would expect countries to fall along the negatively sloped line or countries with high level of private sector credit to GDP in 1995 to have slower private sector credit growth and vice versa).
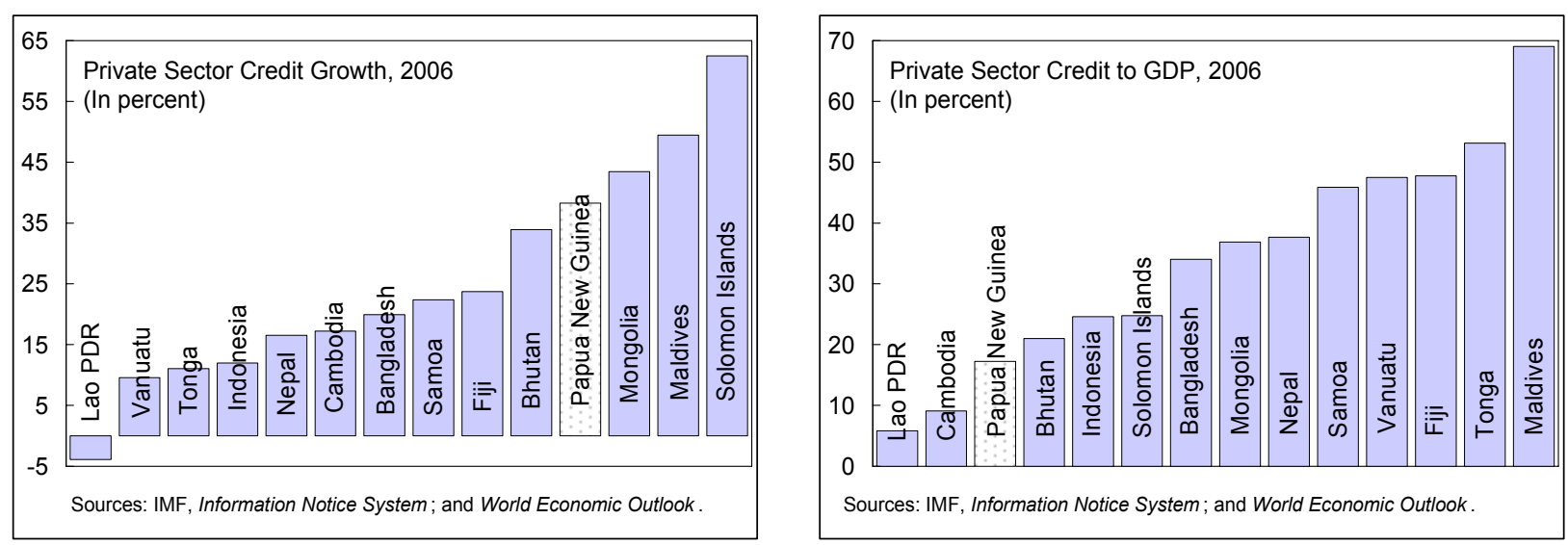

\section{Regulatory and Supervisory Framework}

\section{Beginning in 2000, the authorities undertook a significant revamping of the} regulatory framework. The current framework now encompasses laws governing the central bank, commercial banks and finance institutions, saving and loans, superannuation funds, and life insurance companies that were new or reformed at that time. The most recent reform was in 2007 relating to the superannuation industry to improve and further strengthen the effectiveness of regulations and supervision. ${ }^{6}$ The financial sector's regulatory framework is transparent and is posted on Bank of Papua New Guinea (BPNG)'s website. Most institutions including the two largest superannuation funds disclose their financial results and are regularly audited as required by law. Papua New Guinea does not have an explicit deposit insurance

\footnotetext{
${ }^{6}$ A key change was the requirement for compulsory superannuation coverage for companies to 15 from 20 employees while the change to also include noncitizens was delayed for a year.
} 
system. ${ }^{7}$ New legislation has been passed by the parliament governing the newly-revived National Development Bank which aims to expand its activities into the microfinance sector with deposit-taking and lending to districts. However, the BPNG has not yet issued it a license for microfinance.

8. The banks' supervisory framework is fully compliant with the 1988 Basel I Core Principles and efforts are being made to follow the Basel II recommendations. The outstanding issues are primarily related to capacity building and the establishment of a comprehensive bank database. Commercial banks, finance institutions and superannuation funds are supervised once a year through on-site examinations. Off site supervision is conducted quarterly. Currently, there are plans to extend supervision to all insurance companies.

9. Plans are underway to introduce a credit registration system for banks. Currently, borrower credit information is shared only informally. The International Finance Corporation is assisting the BPNG in setting up a credit bureau, which the commercial banks welcome.

10. The POMSoX rules and regulations closely follow the Australian stock exchange (ASX) model. The stock market regulations are considered to be generally appropriate although oversight is being tightened. The 1997 parliamentary passage of the Securities Act and Company Act paved the way for establishing the legal framework governing the exchange, and in 1998 POMSoX was incorporated as a private company. While there is a concentration of large shareholders, small investors are permitted to purchase shares in listed companies.

11. The liberalization of the capital account since 2005 has contributed to a conducive environment for financial sector growth. A key innovation, since 2005 , is the permission to allow nonresident companies (notably mining) to borrow from banks. Foreign exchange accounts by both residents and nonresidents are permitted. Short-term commercial credits with less than one month maturity are not actively regulated. Large financial institutions are taking increasing advantage of investment opportunities abroad, although improved domestic economic conditions could offset the anticipated outflows.

\section{Performance of the Financial Sector}

\section{Capital Adequacy}

12. Backward looking indicators of capital adequacy are strong. At end-June 2007, commercial banks' capital to risk weighted assets remained comfortable at 25 percent, against the prudential minimum requirement of 12 percent. This is significantly higher than the comparator Asian low income and small countries (LISC) ${ }^{8}$ where the average ratio was

\footnotetext{
${ }^{7}$ Like Papua New Guinea, Australia, New Zealand, and Singapore have implicit deposit insurance; by contrast, other neighbors such as Indonesia, Malaysia, and Thailand have explicit deposit insurance.

${ }^{8}$ The sample includes Bangladesh, Bhutan, Brunei Darussalam, Cambodia, Fiji, Kiribati, Lao P.D.R., Maldives,
} 
18.3 percent at end-2006, and also higher than selected countries shown in the figure below. At the same time, latest data for Tier 1 capital to risk weighted assets in the Papua New Guinea banking system also shows a comfortable level (16.8 percent in June 2007) against the prudential requirement of 8 percent.
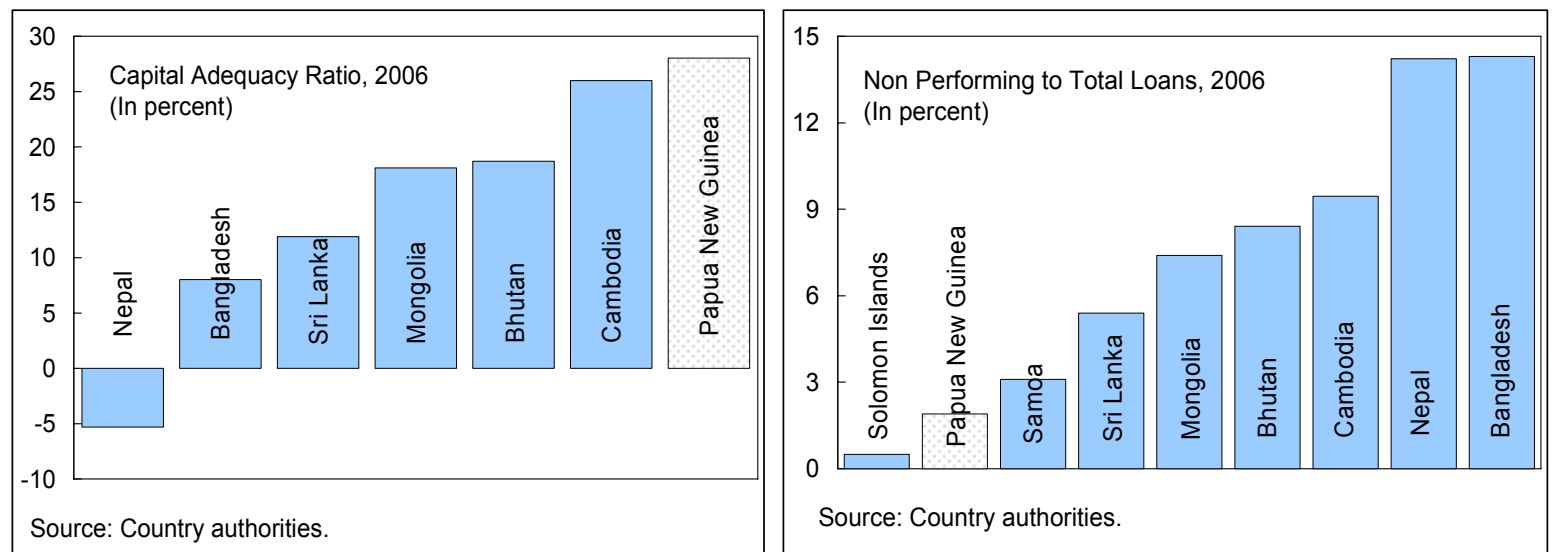

\section{Asset Quality}

13. Commercial banks' asset quality is reasonably sound. Banks hold about a third of their portfolio in government securities, and have a preference for short-term instruments. In terms of lending quality, the ratio of nonperforming loans to total loans declined significantly from 16.9 percent to 1.8 percent from 2000 to 2007; comparatively, selected Asian countries had higher average ratios, including those that have also seen rapid rates of credit growth in recent years. At the same time, both Papua New Guinean banks and finance companies have maintained high provisioning ratios of loans losses relative to their NPLs.

\section{Personal and commerce sectors comprise an important share of bank credit,} while building and construction, and transport and communication have grown. Outstanding advances to mining and quarrying had also grown significantly over the past year (likely associated with the 2005 liberalization of lending to nonresident companies and increased mining activity) but fell substantially in September 2007.

Marshall Islands, Micronesia, Mongolia, Myanmar, Nepal, Palau, Papua New Guinea, Samoa, Solomon Islands, Sri Lanka, Timor-Leste, Tonga, and Vanuatu. 

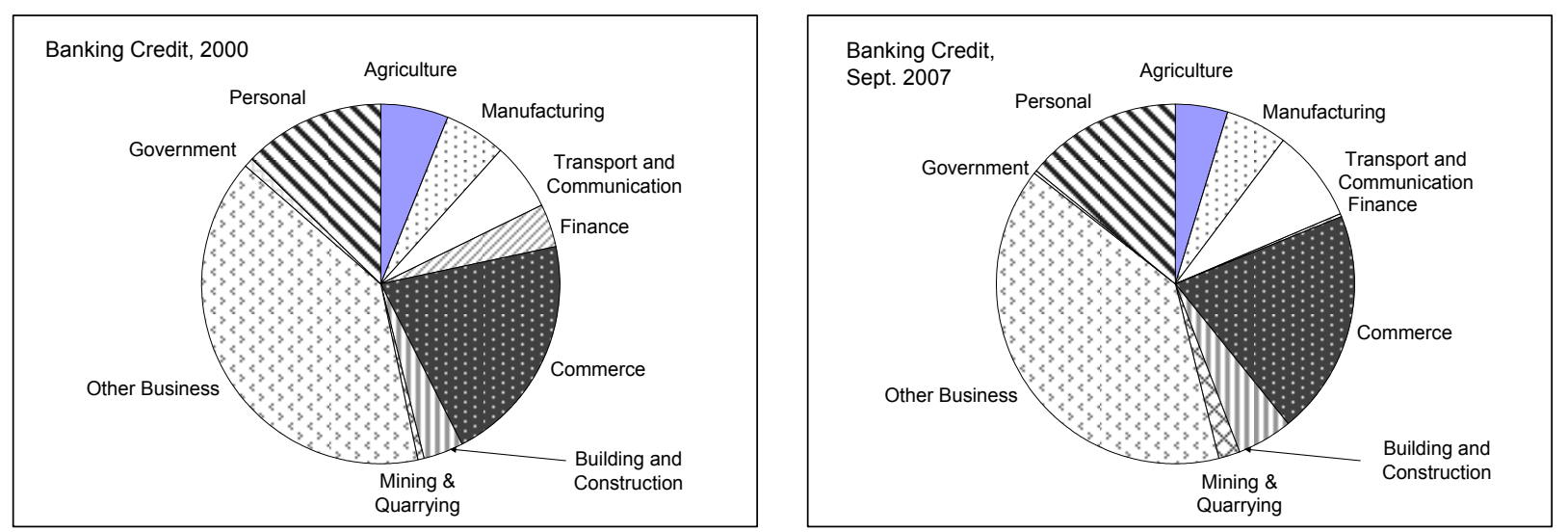

15. While asset quality in terms of total assets is generally not yet of concern, certain underlying trends over the past year could be noted which may stretch supervisory capacity. Banks' zero risk assets to total risk-weighted assets fell from 53 percent to 48 percent in June 2007 (y/y), while the share of 50 percent risk-weighted assets rose from 4 percent to 13 percent. Also, the stock of NPLs and past due loans have started to rise from negative growth in past years, although they are stable in relation to total loans. The NPLs of the National Development Bank have been reported to be around 100 percent on "old" and 20 percent on "new" loans.

16. At the same time, the overall banking system's large borrower exposure is considered high. In particular, the exposure of the 25 largest borrowers against banking system's total prudential capital base was about 100 percent in June 2007, although individual borrower exposures have not been high.

17. The rapid expansion of the superannuation funds so far does not seem to have an adverse effect on asset quality. While Nasfund and Nambawan Super have invested in the domestic equity and property markets, they have also expanded overseas investments to diversify their portfolio and now earn higher returns in both fixed income assets as well as equities (total international investments for the two funds accounted for 23.0 percent and 17.4 percent, respectively in 2006). Over the past few years, both funds have also enjoyed rapid asset growth. 


\section{Management Quality and Conduct}

18. The return on assets, which measures the ability of management to utilize real and financial resources of a bank to generate returns, rose from 1.2 percent to 2.8 percent during 2000-07. The figure here shows Papua New Guinea's return on assets relative to comparator Asian countries. Management accountability in key financial institutions is evidenced by the regular publication of financial reports and company information posted on their respective websites for the benefit of shareholders and customers.

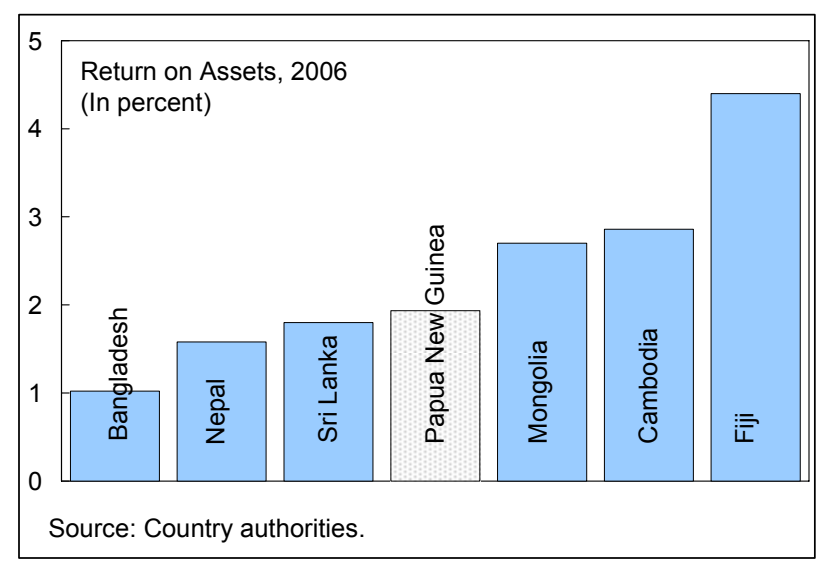

\section{Interest Rate Structure and Earnings Performance}

19. Interest rate spreads (lending minus deposit rates) have declined in recent years (see figures below). Spreads were as high as 11 percent before easing to a still high 9.6 percent in 2006, likely reflecting macroeconomic uncertainty, high administrative costs of banks in rural areas, limited bank competition, and low incentive to attract deposits given banks' relative preference to hold government paper in light of limited investment opportunities. While Papua New Guinea's nominal lending rates in 2006 (10.6 percent) were lower than the LISC average (14.0 percent), real lending rates were comparable ( 7.0 percent). In comparison to U.S., Australia, and Indonesia, real lending rates are higher in Papua New Guinea, although they have declined over the years in part due to lower inflation.
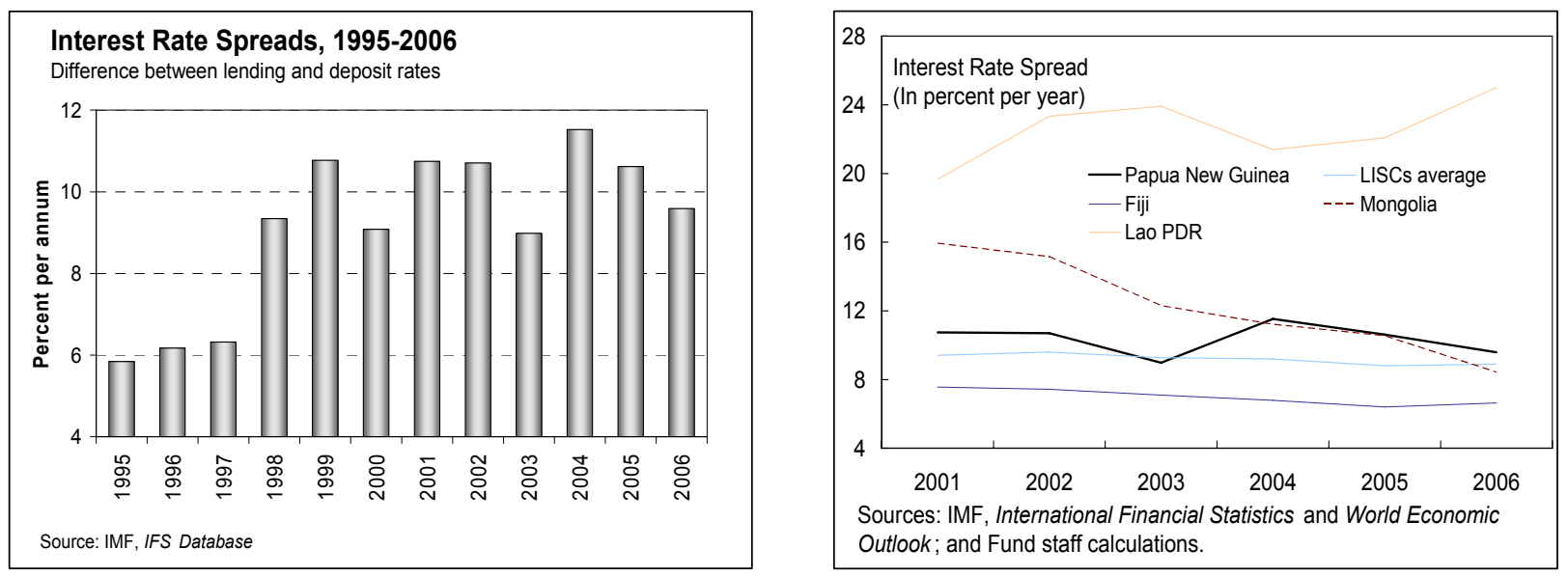

20. Both banks and superannuation funds have enjoyed high profitability in recent years. As the return on assets rose, the return on equity also increased from 21.7 percent to 38.9 percent over the same period. By contrast, low income and small Asian countries on average show an equivalent return on assets ( 3.0 percent), but a lower return on equity 
(29.5 percent) as of 2006. The largest superannuation funds, Nambawan Super and Nasfund, enjoyed high net after tax return (16 and 10 percent, respectively in 2006).

\section{Liquidity}

21. Liquidity in the financial system is high, constituting large holdings of government paper. Commercial banks' liquidity (average liquid assets to total deposits) rose from 54 percent in 2002 to around 75 percent in 2007-significantly higher than the average for low income and small Asian countries (27 percent).

\section{Efficiency}

\section{Banks have been generating strong profits and dividends resulting from a} favorable economic environment and high commodity prices, but also due to their ability to control expenses. The "efficiency ratio" measured by noninterest expenses to gross income is around 40 percent and average gross income per employee $(\mathrm{K} 274,000)$ for the banking system is significantly greater than per employee costs $(\mathrm{K} 41,000)$.

Papua New Guinea: Banking System Financial Soundness Indicators, 2006

(in percent)

\begin{tabular}{lr}
\hline \multicolumn{1}{c}{ Indicator } & All banks \\
& \\
\hline & 24.8 \\
Regulatory capital to risk-weighted assets & 17.9 \\
Tier1 capital to risk-weighted assets & \\
& 1.8 \\
Nonperforming loans (NPLs) to total loans (both net of accrued interest on NPLs) & 1.7 \\
Nonperforming loans (net of provisions and accrued interest) to regulatory capital & 73.6 \\
Loan loss provisions to nonperforming loans (net of accrued interest) & \\
& 6.9 \\
Return (before tax) on assets & 60.1 \\
Return (before tax) on equity & 45.8 \\
Interest margin to gross income & 39.0 \\
Noninterest expenses to gross income & 39.5 \\
Foreign exchange gains/losses to gross income & 4.4 \\
Total operating expenses over average assets & -1.5 \\
Average interest rate paid on interest-bearing liabilities & 7.2 \\
Average interest rate received on interest-earning assets & 273.9 \\
Gross income per employee (thousand domestic currency units) & 40.5 \\
Staff expenses per employee (thousand domestic currency units) & \\
& 7.9 \\
Share of foreign-currency deposits in total deposits & 37.0 \\
Ratio of net loans to total deposits & 75.9 \\
Liquidity ratio & \\
\hline &
\end{tabular}

Source: Estimates based on annual reports of banks and data provided by the central bank.

23. The thin securities markets limit financial deepening. Stock market capitalization (at over 100 percent of GDP) is amongst the highest as compared to the group of low income 
and small Asian countries (15 percent of GDP), helped by dual listing of several companies on both the Papua New Guinea and foreign stock exchanges (mainly Australia). However, at the same time, comparatively, there are fewer companies and the annual market turnover is relatively low ( 0.5 percent of GDP vs. 1.6 percent of GDP for sample of LISC countries). At present, there are only two brokers and relatively high shareholder concentration. The thin stock exchange potentially could limit the ability of firms (especially in the nonmineral sector) to secure equity financing, hence further increasing their reliance on banks. As regards other markets, there is only a primary government securities market with financial institutions holding about 85 percent of these securities.

\section{E. Constraints, Vulnerabilities, and Risks}

\section{Papua New Guinea ranks relatively low in a global ranking of "getting credit"} (115 out of 175 countries), according to the latest World Bank's Doing Business survey. Focusing on the sub-categories, the "legal rights" index performs equally well relative to the region, while given an absence of a credit registry in Papua New Guinea, the "credit information index" (representing the access and quality of credit information available through public registries or private bureaus) receives a 0 rating out of a possible 6 (with a 2 rating for South Asia and East Asia/Pacific region). At the same time, Papua New Guinea also ranks relatively low in the categories of "enforcing contracts" (162) and "closing a business" (97).

Doing Business: Papua New Guinea and Comparators 1/

\begin{tabular}{lccccc}
\hline & $\begin{array}{c}\text { Overall } \\
\text { Ease }\end{array}$ & $\begin{array}{c}\text { Protecting } \\
\text { Investors }\end{array}$ & $\begin{array}{c}\text { Enforcing } \\
\text { Contracts }\end{array}$ & $\begin{array}{c}\text { Closing a } \\
\text { Business }\end{array}$ & $\begin{array}{c}\text { Getting } \\
\text { Credit }\end{array}$ \\
\hline Papua New Guinea & 84 & 33 & 162 & 97 & 115 \\
East Asia and Pacific 2/ & 77 & 77 & 86 & 98 & 99 \\
South Asia 2/ & 107 & 70 & 132 & 113 & 102 \\
\hline
\end{tabular}

Source: World Bank, Doing Business Indicators, 2008.

1/ Economics are ranked on their ease of doing business, from 1-178, with first place being the best.

2/ Simple average of countries in the region. 


\section{Doing Business-Getting Credit Sub-indices: Papua New Guinea and Comparators}

\begin{tabular}{lcccc}
\hline & $\begin{array}{c}\text { Legal } \\
\text { Rights } \\
\text { Index 1/ }\end{array}$ & $\begin{array}{c}\text { Credit } \\
\text { Information } \\
\text { Index 1/ }\end{array}$ & $\begin{array}{c}\text { Public Registry } \\
\text { Coverage } \\
\text { (\% of adults) }\end{array}$ & $\begin{array}{c}\text { Private Bureau } \\
\text { Coverage } \\
\text { (\% of adults) }\end{array}$ \\
\hline $\begin{array}{l}\text { Papua New Guinea } \\
\text { East Asia and Pacific }\end{array}$ & 5.0 & 0.0 & 0.0 & 0.0 \\
South Asia & 4.5 & 1.9 & 5.5 & 10.8 \\
& 3.9 & 1.9 & 0.7 & 1.9 \\
\hline
\end{tabular}

Source: World Bank, Doing Business Indicators, 2008.

1/ Higher score the better. Legal Rights Index has a score from 0-10 and Credit Information Index from 0-6.

\section{The scope for financial deepening is also constrained by weak corporate} insolvency and debt recovery procedures (see Appendix Table I, lines 1-20). ${ }^{9}$ These procedures include formal and informal rules for enforcement of debt contracts, bankruptcy liquidation, and the rehabilitation of distressed firms. We note that while the procedures for acquiring collateral are comparable to sample countries, the process of collateral enforcement is weaker. More generally, a high degree of communal land ownership (about 97 percent of all land) and less liquid asset markets could be constraining the ability of lending institutions to secure and especially enforce collateral requirements. Given weaknesses in formal debt recovery procedures, informal procedures could be preferred (e.g., lines 11-14). More positively, the judicial processes for debt recovery (lines 17-20) appear to be relatively more efficient in Papua New Guinea compared with most sample countries including Bangladesh and Indonesia.

\footnotetext{
${ }^{9}$ We obtained an assessment of processes for debt recovery from a banking expert in Papua New Guinea during the 2007 Article IV mission. The table compares Papua New Guinea with several low and middle income countries in the region reported in previous studies (Hussain and Wihlborg, 1999 and Hussain, 2002). The country wide comparisons should be treated with caution since we used different time periods, and procedures would be expected to improve over time. Also, there is a risk that each individual country survey could employ a different "scale" for evaluation.
} 


\section{Stress Tests for Papua New Guinea Banking System}

\section{In order to examine the vulnerability of the banking sector, stress tests were} performed. ${ }^{10}$ Our analysis uses the 2006 audited annual reports of the four commercial banks as well as end-2006 banks' financial statements provided by BPNG. The sensitivity analysis replicates plausible scenarios from the late 1990s economic and financial crisis in Papua New Guinea as well as aspects of the 1997 Asian crisis that include a rise in the share of nonperforming loans to total loans to 15-20 percent and a near doubling of interest rates. Looking forward, these events could arise in an environment of weak domestic policies and

\section{Box. What are Stress Tests?}

Stress tests are analytical techniques for quantifying the vulnerability of banks' portfolio to exceptional but plausible changes in the macro environment. ${ }^{1}$ Under the stress tests, the effect of shocks on banks' soundness is measured by their impact on banks' regulatory capital to risk-weighted assets.

Credit risk stress tests quantify the effect on banks' soundness of deterioration in the average asset quality of their portfolios. The deterioration of asset quality has both a repricing and a net income effect on banks' regulatory capital. The following credit risk tests were applied:

(i) Increase in nonperforming loans: the nonperforming loans approach involves reclassification of existing current loans to nonperforming, with corresponding increases in the level of specific provisions and a decrease in the level of general provisions;

(ii) Large exposures to borrowers: the stress test on banks' large exposures to borrowers is a specific parameterization of the credit risk stress test based on the nonperforming loans approach. It involves the reclassification of all loans to each bank's largest borrowers (assumed to be current prior to the stress test) to nonperforming, with corresponding increases in the level of specific provisions and a decrease in the level of general provisions; and

(iii) Increased provisioning approach on existing NPLs: the provisioning approach involves the reclassification of existing nonperforming loans into categories indicating a higher degree of impairment. A corresponding increase in the level of specific provisions would need to be set aside by banks to cover the upwardly revised expectations of losses.

Finally, we also performed a test for migration of risk-weighted assets from low risk to high-risk weights.

Interest rate risk is estimated using the duration model, which measures the impact of interest rate changes only on the price of securities held by banks. Duration can be defined as the weighted-average of time to maturity, using the present value of cash flows as weights. In Papua New Guinea, banks hold government securities only sold in the primary market.

\footnotetext{
${ }^{10}$ The stress tests reported for the Papua New Guinea banking system in this sub-section were performed using templates accompanying the "Stress Test Toolkit" prepared by Plamen Iossifov (IMF), 2007.
} 
rapid decline in commodity prices. The main focus of the analysis is on (i) credit and borrower concentration risk; (ii) risk arising from migration of assets from low to high risk-weight groups; and (iii) interest rate risk. Foreign exchange risk is not analyzed since we do not have sufficient individual bank data on foreign exchange (FX) assets and FX liabilities. From the aggregate data that is available on banks, it appears that the risk is not high at present (FX deposits comprise only 8-10 percent of total deposits and FX loans constitute around 6-10 percent of total loans). Moreover, liquidity risk does not seem to be a concern at present since the liquid assets to total deposits were 76 percent in 2006.

\section{Individual stress test analysis shows that the banking system is resilient to moderate shocks: ${ }^{11}$}

- $\quad$ Starting with baseline capital asset ratio of 24.8 percent (regulatory minimum is 12 percent), the reclassification of existing NPLs indicating a higher degree of impairment for each NPL category ${ }^{12}$ (i.e., 33 percent in each category) only shows a marginal decline in the capital asset ratio.

- $\quad$ The capital asset ratio falls to 22.1 percent under the condition that all existing NPLs shift from substandard to bad.

- While the current NPLs to total loans is low at the present time, the deterioration of loans so that 15 percent of current loans become substandard NPLs reduces the capital to risk weighted assets ratio to 22.2 percent. This scenario is similar to the events that marked the 1997 Asian crisis (see Hussain and Wihlborg, 1999) and the late 1990s Papua New Guinea crisis.

- $\quad$ The interest rate risk test (duration test) for a doubling of interest rates (as in the Papua New Guinea crisis) reduces the ratio to 20.4 percent.

- $\quad$ The stress tests indicate that the risk from large borrower exposure is high. The loss of the single largest borrower of each bank reduces capital adequacy ratios to 18.3 percent.

- $\quad$ The test for migration of assets from low to high risk weights (by 25 percent) reduces the capital asset ratio to 17.7 percent.

- In the case that 15 percent of current loans become "loss" or bad loans (delinquent for more than 360 days), the capital asset ratio declines to 14.6 percent.

\footnotetext{
${ }^{11}$ The discussion for individual stress tests in this paragraph corresponds to declining capital assets ratios in the figure below (from left to right).

${ }^{12}$ According to Papua New Guinea's prudential standards, loans are classified as (i) pass, or acceptable; (ii) special mention (past due for 60-90 days); (iii) substandard (past due for 90-180 days); (iv) doubtful (past due for 180-360 days); and (v) loss (past due for more than 360 days).
} 
- An extreme crisis scenario involving the loss of each bank's five largest borrowers almost exhausts the capital of the banking system.

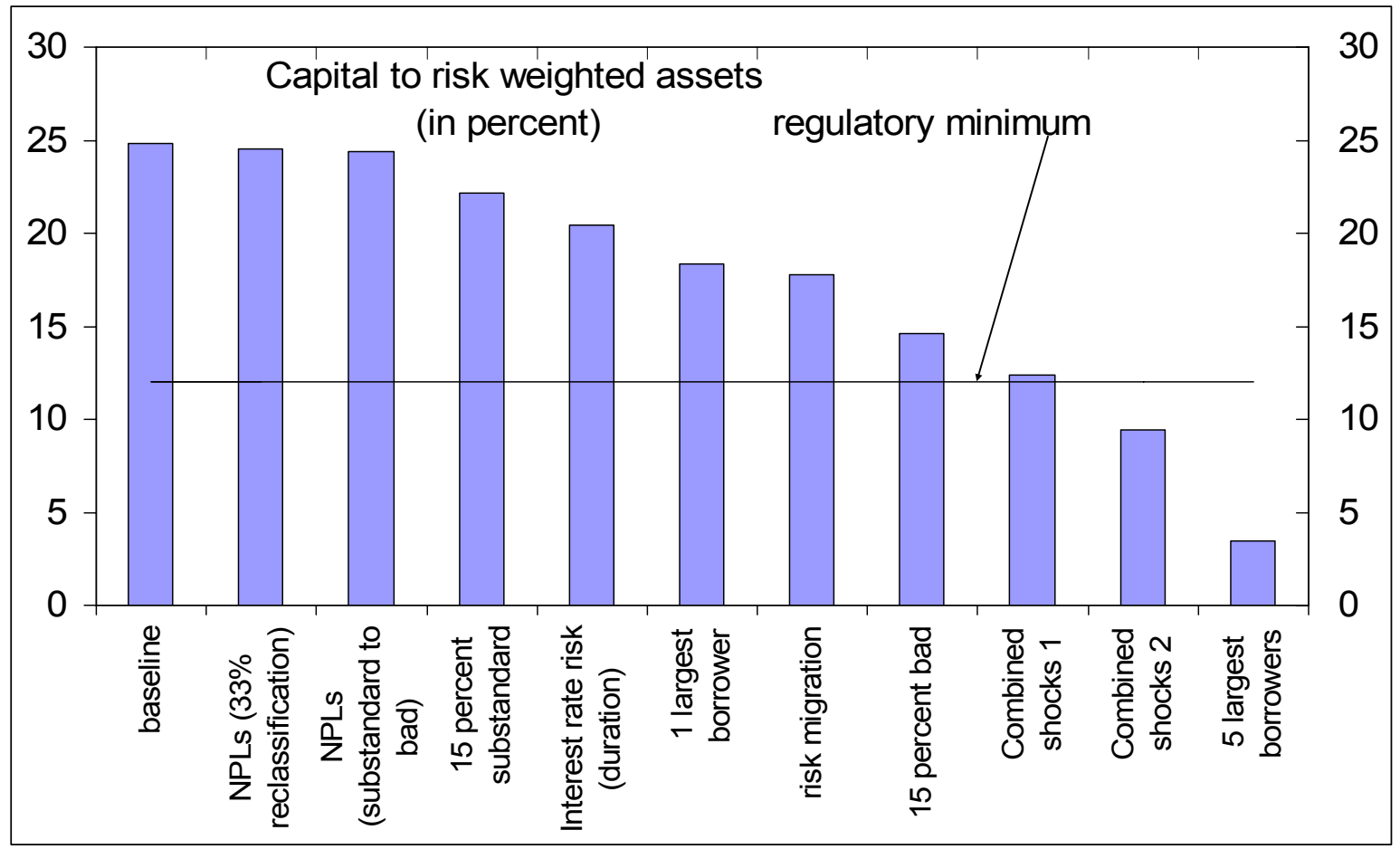

28. The integrated approach using a "scenario" analysis combining some of the above individual tests shows a greater degree of vulnerability in the banking system. We examined two combined shock scenarios (see figure above):

- Combined shocks 1: 15 percent of current loans become substandard, doubling of interest rates, and migration of assets from low to high risk weights (by 25 percent) reduces the capital adequacy ratio to 12.4 percent (to the required regulatory minimum); and

- Combined shocks 2: loss of the largest borrower, doubling of interest rates, and migration of assets from low to high risk weights (by 25 percent) leads to a deterioration of capital adequacy ratio to 9.4 percent (below the required regulatory minimum). Although not included in the figure, the most extreme scenario, which involves the loss of the five largest borrowers in each bank, along with the interest rate and migration risk, completely exhausts the banking system capital.

\section{F. Conclusions and Implications}

29. The backward looking soundness indicators show that the financial system is

sound. However, stress test analysis finds that while the system can absorb moderate shocks, a combination of shocks brought about by weak macro policies and an unfavorable external environment (with declining commodity prices) could add significant vulnerability. Our examination of the financial system illustrates that financial deepening is still low despite high 
credit growth in recent years. Looking forward, continued high credit growth and growing international investment opportunities for financial institutions requires that these institutions strengthen their internal risk management systems in addition to improved supervision by the authorities. In this regard, the authorities are appropriately considering the establishment of a credit bureau. The authorities should also ensure that due diligence and fit and proper criteria are applied for all new applicants for licenses, including for the Development Bank. Moreover, prudent macroeconomic policies are the only means of averting financial crisis given past experiences of Papua New Guinea and other countries. In order to enhance financial deepening, the authorities should reduce structural rigidities in the system, including improved rules for collateral and procedures for insolvency and debt recovery, and further develop the securities markets. In this regard, a Financial Sector Assessment Program (FSAP) conducted jointly by the IMF and World Bank could be useful to provide an assessment of recent developments and recommendations for the way forward. 


\section{REFERENCES}

Abdelati, Wafa, 2007, Banking Soundness and Financial Intermediation, IMF Staff Country Report No. 07/230 (Washington: International Monetary Fund).

Asian Development Bank, 1998, Local Study of Insolvency Law Regimes. Regional Technical Assistance Project. Insolvency Law Reform. TA No. 5795-REG, Manila.

Bank of Papua New Guinea, 2006, Financial Soundness Indicators.

— 2007, Financial Soundness Indicators.

__ Regulatory and Supervisory Framework. Available via Internet: http://www.bankpng.gov.pg/

_ 2006, Presentation to the Savings \& Loans Societies' Credit Union Day, Them "Credit Union Making a World of Difference," Overview of Financial Sector and Savings and Loan Societies' Legislative Framework.

Berns, Rudolfs, 2007, Efficiency of Slovene Banking Sector in the EU Context, IMF Staff Country Report No. 07/182 (Washington: International Monetary Fund).

Blaschke, Winfred, Matthew T. Jones, Giovanni Majnoni, and Soledad Martinez Peria, 2001, "Stress Testing of Financial Systems: An Overview of Issues, Methodologies, and FSAP Experiences." IMF Working Paper No. 01/88 (Washington: International Monetary Fund).

Briggs, Peter, 2007, "The Financial Sector in Papua New Guinea-A Good Case of Reform," Available via Internet: http://www.treasury.gov.au

Cihak, Martin, 2007, “Introduction to Applied Stress Testing," IMF Working Paper No. 07/59 (Washington: International Monetary Fund).

Dabla Norris, Era and Holger Floekemeier, 2007, "Bank Efficiency and Market Structure: What Determines Banking Spreads in Armenia?," IMF Working Paper No. 07/134 (Washington: International Monetary Fund).

Demirguc-Kunt, Asli, Kane Edwards, and Luc Laeven, 2006, "Determinants of Deposit Insurance Adoption and Design," World Bank Policy Research Working Paper No. 3849 (Washington: World Bank).

Fleisig, Heywood W., and Nuria de la Pena, 2003, "Law, Legal Institutions, and Development: Lessons of the 1990s for Property Rights, Secured Transactions, Business Registration, 
and Contract Enforcement,” (Washington: World Bank).

Hussain, Qaizar, 2002, “The Banking Sector in Bangladesh.” Bangladesh Selected Issues. IMF Country Report No. 02/114.

—_, and Clas Wihlborg, 1999, "Corporate Insolvency Procedures and Bank Behavior: A Study of Selected Asian Countries," IMF Working Paper No. 99/135 (Washington: International Monetary Fund).

International Monetary Fund, 2007, “Box 3: Kazakhstan's Credit Boom-Lessons from International Experience," in Republic of Kazakhstan: 2007 Article IV Consultation, IMF Country Report No. 07/235 (Washington).

— 2007, "Box 3: Stress Test Analysis-The Impact of Adverse Macro Shocks on Banks," in Indonesia: 2007 Article IV Consultation, IMF Country Report No. 07/272 (Washington).

Iossifov, Plamen, 2007, "Stress Test Toolkit” (Washington: International Monetary Fund).

Kina Securities Limited, 2007, Kina Securities Share Index (February 20).

Nasfund Newsletter. Available via Internet: http://www.nasfund.com.pg/

Port Moresby Stock Exchange. Available via Internet: http://www.pomsox.com.pg/

Response of a Banking Expert on the Survey: "Summary Evaluation of Processes for Debt Recovery," 2007 IMF Article IV mission to Papua New Guinea.

Tomasic, Roman, and Peter Little, 1997, Insolvency Law and Practice in Asia. FT Law \& Tax Asia Pacific (Hong Kong SAR: Pearson Professional Limited).

Topalova, Petia, 2007, Rapid Private Sector Credit Growth, Macroeconomic Risks, and Financial Sector Soundness, IMF Staff Country Report No. 07/349 (Washington: International Monetary Fund).

Wilson Kamit, 2006, Monetary and Financial Sector Reforms in Papua New Guinea, a presentation at the Australian National University Economic and Policy Update. Port Moresby.

Worrell, DeLisle, 2004, "Quantitative Assessment of the Financial Sector: An Integrated Approach,” IMF Working Paper No. 04/153 (Washington: International Monetary Fund). 


\begin{tabular}{|c|c|c|c|c|c|c|c|c|}
\hline \multicolumn{9}{|c|}{ Appendix Table I. Summary Evaluation of Processes for Debt Recovery } \\
\hline & $\begin{array}{l}\text { Papua New } \\
\text { Guinea }\end{array}$ & Bangladesh & Indonesia & Korea & Malaysia & Philippines & $\begin{array}{l}\text { Taiwan } \\
\text { Province of } \\
\text { China }\end{array}$ & Thailand \\
\hline & \multicolumn{8}{|c|}{$\begin{array}{l}1=\text { low cost (or not expensive), easy, very efficient, quick; } \\
3=\text { very expensive, very difficult, inefficient and very slow }\end{array}$} \\
\hline $\begin{array}{l}\text { 1. Process for acquiring security } \\
\text { (collateral) over land }\end{array}$ & 1.50 & 3.00 & 2.75 & 1.25 & 1.25 & 1.50 & 1.50 & 1.50 \\
\hline $\begin{array}{l}\text { 2. Process for acquiring security over } \\
\text { other property }\end{array}$ & 1.50 & 2.55 & 2.75 & 1.25 & 1.25 & 1.50 & 1.50 & 1.50 \\
\hline $\begin{array}{l}\text { 3. Process for enforcement of security } \\
\text { over land }\end{array}$ & 2.50 & 3.00 & 3.00 & 1.25 & 1.25 & 2.00 & 1.75 & 1.25 \\
\hline $\begin{array}{l}\text { 4. Process for enforcement of security } \\
\text { over other property }\end{array}$ & 2.00 & 2.50 & 2.50 & 1.25 & 1.25 & 2.00 & 1.50 & 1.75 \\
\hline 5. Process for debt collection & 2.50 & 2.75 & 2.50 & 1.25 & 1.25 & 3.00 & 2.00 & 1.50 \\
\hline $\begin{array}{l}\text { 6. Process for winding up insolvent } \\
\text { corporation }\end{array}$ & 2.00 & 3.00 & 2.50 & 1.25 & 2.00 & 3.00 & 2.00 & 1.50 \\
\hline $\begin{array}{l}\text { 7. Process for } \\
\text { reorganization/restructuring }\end{array}$ & 2.50 & 3.00 & 2.50 & 1.75 & 2.00 & 2.25 & 2.25 & 1.50 \\
\hline 8. Time for winding up & 6-12 months & 7-8 months & 4-6 months & 6-12 months & 6-12 months & $>6$ months & $>6$ months & $>6$ months \\
\hline 9. Time for formal reorganization & 6-12 months & 7-8 months & $\begin{array}{c}12-18 \\
\text { months }\end{array}$ & 2-4 months & 8-12 months & $>18$ months & $8-12$ months & $\begin{array}{c}>18 \text { months } \\
\text { (since 98) }\end{array}$ \\
\hline 10. Time for informal workout & 6-12 months & 7-8 months & 4-8 months & 2-4 months & 2-4 months & \begin{tabular}{c|}
$12-18$ \\
months
\end{tabular} & \begin{tabular}{c|}
$12-18$ \\
months
\end{tabular} & $>18$ months \\
\hline 11. Incidence of bankruptcy/liquidation & Low & Very low & Very low & Low & High & $\mathrm{N} / \mathrm{A}$ & Very low & Low \\
\hline $\begin{array}{l}\text { 12. Incidence of } \\
\text { reorganization/restructuring }\end{array}$ & Low & $\mathrm{N} / \mathrm{A}$ & $\mathrm{N} / \mathrm{A}$ & High & High & $\mathrm{N} / \mathrm{A}$ & Very low & $\begin{array}{l}\text { Very low } \\
\text { (since 98) }\end{array}$ \\
\hline \multicolumn{9}{|l|}{ Workouts preferred because: } \\
\hline $\begin{array}{l}\text { 13. Bankruptcy procedures are a real } \\
\text { alternative }\end{array}$ & Not really & No & $\begin{array}{c}\text { Adverse } \\
\text { effect }\end{array}$ & $\begin{array}{c}\text { Government } \\
\text { encourages } \\
\text { workout }\end{array}$ & Yes & No & No & Yes \\
\hline $\begin{array}{l}\text { 14. Better outcome than under formal } \\
\text { procedures }\end{array}$ & $\begin{array}{c}\text { In most } \\
\text { cases }\end{array}$ & No & No & \begin{tabular}{|c|} 
No, for \\
secured \\
creditors
\end{tabular} & Yes & No & Yes & No \\
\hline Predictability of positive outcome of: & \multicolumn{8}{|c|}{$\begin{array}{l}1=\text { very high } \\
5=\text { very low }\end{array}$} \\
\hline $\begin{array}{l}\text { 15. Process for security enforcement; } \\
\text { land }\end{array}$ & 3.00 & 5.00 & 5.00 & 2.00 & 2.00 & 2.00 & 2.00 & 2.00 \\
\hline $\begin{array}{l}\text { 16. Process for security enforcement; } \\
\text { other than land }\end{array}$ & 3.00 & 4.50 & 5.00 & 4.00 & 2.00 & 2.00 & 1.00 & 3.00 \\
\hline $\begin{array}{l}\begin{array}{l}\text { 17. Judicial handling of security } \\
\text { enforcement }\end{array} \\
\end{array}$ & 3.00 & 5.00 & 5.00 & 3.00 & 2.00 & 3.00 & 2.00 & 2.00 \\
\hline 18. Judicial handling of debt collection & 2.00 & 5.00 & 5.00 & 3.00 & 2.00 & 3.00 & 1.00 & 2.00 \\
\hline $\begin{array}{l}\begin{array}{l}\text { 19. Judicial handling of } \\
\text { bankruptcy/liquidation }\end{array} \\
\end{array}$ & 3.50 & 5.00 & 5.00 & 4.00 & 2.00 & 4.00 & 5.00 & 4.00 \\
\hline 20. Judicial handling of rehabilitation & 3.50 & 5.00 & 5.00 & 4.00 & 3.00 & 4.00 & 5.00 & 5.00 \\
\hline
\end{tabular}




\section{Tax Summary $2008^{1}$}

\section{A. Direct Taxation}

\section{Taxation of Individuals}

1. The tax year coincides with the calendar year. Residence is defined as physical presence in Papua New Guinea (PNG) for more than six months out of a given tax year. Resident individuals are taxed on global income from all sources, subject to double-taxation treaties. Nonresident individuals are liable for tax only on income derived from PNG sources. The maximum number of dependents for whom a tax rebate may be claimed was reduced from four to three in the 2004 Budget.

2. There are two separate types of assessment: (i) a fortnightly salary or wages tax assessment; and (ii) an annual non-salary or wages income assessment. Expenses of earning income are fully deductible, and there are no capital gains or gift taxes. The tax rates on assessed income are shown in Table IV.1.

Table IV.1. Individual Resident Income Tax Rates From 1 January 2008

\begin{tabular}{|l|c|}
\hline Income Bracket & Marginal Tax Rate (Percent) \\
\hline Below K7,000 & 22 \\
\hline $\mathrm{K} 7,001$ to $\mathrm{K} 18,000$ & 30 \\
\hline $\mathrm{K} 18,001$ to $\mathrm{K} 33,000$ & 35 \\
\hline $\mathrm{K} 33,001$ to $\mathrm{K} 70,000$ & 40 \\
\hline K70,001 to K250,000 & 42 \\
\hline Above K250,000 & 4 \\
\hline
\end{tabular}

\section{Taxation of Companies}

3. Tax years generally correspond to calendar years, unless there is a sufficient reason to deviate from that rule (e.g., if the parent company has a different tax year). A company is considered resident for tax purposes if it is incorporated in PNG, has its management in PNG, or is controlled by PNG residents. A resident company is taxed on its global income from all sources. Nonresident companies pay tax only on PNG sourced income.

\section{The general company tax rate is $\mathbf{3 0}$ percent, except for authorized}

superannuation funds, for which the applicable rate is 25 percent. Taxable income generally corresponds to accounting income. Company income tax is payable as advanced payment tax (APT), so that companies pay tax on the current year's income. Advanced payment tax is payable in three equal installments on the last business day of April, July, and October each year. Business losses can be carried over for up to 20 years; they cannot be carried back.

\footnotetext{
${ }^{1}$ The information to this annex has been provided by the authorities of Papua New Guinea. For additional information see the Internal Revenue Commission website: http://www.irc.gov.pg/index.htm
} 
5. Special Temporary Rates for Agriculture and Tourism apply. The 2004 Budget introduced a 20 percent tax rate would apply for 10 years to agricultural projects with an investment of K5 million or more commencing between 1 January 2004 and 31 December 2006. The 2006 Budget extended the eligibility period for this temporary concessional tax rate from 31 December 2006 to 31 December 2011. The 2006 Budget also reduced the amount needed to be invested to qualify from K5 million to K1 million. The 2007 Budget introduced a temporary concessional tax rate of 20 percent for 10 years from the date of operation and the availability of infrastructure tax credits for an indefinite period but limited in amount to 1.5 percent of gross income in each year and to the income tax liability for large scale tourist accommodation facilities involving investment of US \$10 million or more where construction commences within five years from 1 January 2007 and the resulting facility has at least 150 guest rooms.

\section{Other assistance measures for tourism and agriculture have been introduced} since 2005, including a double deduction for export market development costs for tourism operators and accelerated depreciation for capital expenditure. These concessions were expanded in 2007. A double deduction for staff training costs was introduced. The depreciation allowable for the first year was increased to 55 percent in 2007. The purchase by foreign tourists of travel and accommodation in PNG while outside the country will be exempt from GST from 1 January 2007. A 150 percent tax deduction for research and development and agricultural extension services, was introduced in the 2004 Budget. The level of infrastructure tax credits available to agriculture was increased from 0.5 percent of assessable income to 0.75 percent of assessable income in 2005. This was further increased to 1.5 percent of assessable income in 2006.

7. Dividend withholding tax of 17 percent is applicable to all dividends paid by resident companies and received by resident companies from sources outside of Papua New Guinea. Dividend withholding tax on dividends paid to nonresidents, resident individuals and resident trust estate is a final tax. While the standard rate of dividend withholding tax on dividends paid to nonresidents is 17 percent, under some of PNG's bilateral double tax treaties, a lower rate is prescribed. A DWT of 10 percent applies to dividends from mining companies. Dividends from petroleum and gas operations are not subject to DWT.

8. Interest withholding tax of 15 percent was introduced in 1999. Interest withholding tax on interest paid to nonresidents is a final tax. Interest paid by mining and petroleum companies to nonresident financial institutions is exempt.

\section{Taxation of Mining and Petroleum Companies}

9. Mining and petroleum companies are subject to different rates of taxation than non-resource companies as summarized in Table IV.2. Corporate income tax for mining companies is payable as APT, as for non-resource companies. At the beginning of each year, the Internal Revenue Commission (IRC) assesses the APT estimate lodged by the tax payer and issues an APT assessment to the mining company. The company then pays this assessment 
(in Kina) to the BPNG account at the Federal Reserve Bank in New York in three equal installments in April, July, and October. Any differences between the APT assessment and final income tax assessment (also known as wash-up) for mining companies are requested to be paid in U.S. dollars. The payment mechanism of corporate income tax for petroleum companies is same as for mining companies, except that APT lodgment, assessment and payment are all made in U.S. dollars. Any differences between the APT assessment and final income tax assessment or "wash-up" for petroleum companies are requested to be paid in U.S. dollars.

10. Business losses can be carried over indefinitely.

Table IV.2. Taxation Rates of Petroleum, Gas and Mining Companies

\begin{tabular}{|c|c|c|c|}
\hline & $\begin{array}{l}\text { Mining } \\
\text { Companies }\end{array}$ & $\begin{array}{l}\text { Gas } \\
\text { Companies }\end{array}$ & Petroleum Companies \\
\hline Income tax & $\begin{array}{l}30 \text { percent } \\
\text { (applicable } \\
\text { for resident } \\
\text { companies } \\
\text { only) }\end{array}$ & 30 percent & $\begin{array}{l}\text { Operations that began before } 2001 \text { : } \\
\quad 50 \text { percent } \\
\text { Operations that arise from a } \\
\text { prospecting license granted between } \\
2003 \text { and } 2007 \text { and developed before } \\
2018 \text { : } \quad 30 \text { percent } \\
\text { Operations not included above: } \\
\quad 45 \text { percent: } \\
\quad 50 \text { percent }\end{array}$ \\
\hline Dividend withholding tax & 10 percent & None & None \\
\hline Mining levy & $\begin{array}{l}\text { Mining levy } \\
\text { to be } \\
\text { reduced by } \\
5 \text { percentage } \\
\text { points every } \\
\text { year until it } \\
\text { expires in } \\
2008\end{array}$ & None & None \\
\hline Royalties & $\begin{array}{l}2 \text { percent on } \\
\text { the f.o.b. } \\
\text { sales }\end{array}$ & $\begin{array}{l}2 \text { percent on } \\
\text { gross } \\
\text { revenues } \\
\text { from gas } \\
\text { sales }\end{array}$ & $\begin{array}{l}2 \text { percent on gross revenues from } \\
\text { petroleum sales }\end{array}$ \\
\hline
\end{tabular}

${ }^{*}$ Rate for nonresident mining companies is 40 percent, no distinction between resident and nonresident companies for petroleum and gas companies.

\section{Other Provisions for the Mining and Petroleum Sectors}

\section{A mining levy was introduced in July 1999 to capture the windfall gain of the} mining industry from the introduction of the VAT, which resulted from the zero-rating of their exports in conjunction with the removal of the 11 percent basic import duty for all sectors of the economy. In 2002 the government commenced phasing out the mining levy over a 
four-year period, intending to reduce it by one-fourth of the original amount every year. However, phase out of the mining levy was temporarily suspended in 2003. In 2004 the government reinstituted the phase out at the rate of 5 percentage points, and an additional 5 percentage points per annum every year thereafter, with the phase out to be complete by 2008 . However, some payments for previous years assessments are expected to be received in 2008.

\section{To promote new petroleum projects, the rate of corporate income tax was} reduced from 50 percent to 45 percent and then effectively to 30 percent for petroleum projects. The reduced rate does not apply to projects that existed at the time of reduction in January 2001. The government has also introduced special fiscal incentives for Petroleum Prospecting Licenses issued before January 1, 2008, which convert to Petroleum Development Licenses before January 1, 2018. This practically entitles all petroleum projects that commence operation between 2003-17 to a reduced petroleum corporate tax rate of 30 percent for the life of the project. The reduced corporate income tax rate is aimed at providing incentives for new petroleum exploration.

13. Additional profit taxes, which were applied to mining and petroleum company income that exceeded an internal rate of return of at least 20 percent, have been abolished for mining and petroleum projects but not gas ones such as the prospective Gas to Australia project.

14. A national resource tax is imposed by the national government but paid to provincial governments and landowners as a royalty of 2 percent of the net value of output from mining, petroleum and gas projects.

\section{Resource companies are allowed a full credit for the cost of approved} infrastructure developments that they undertake for the benefit of communities. This Infrastructure Tax Credit (ITC) applies to the region in which they operate or elsewhere. The deduction is limited to the lesser of 0.75 percent (reduced from 2 percent from Jan 2001) of assessable income or tax payable for the year.

\section{Taxation of Superannuation Funds}

\section{All companies employing 20 or more persons are required to provide}

superannuation for their employees. Employee contributions are deducted from gross basic salary at a minimum rate of 5 percent, while the employer contributes 7 percent of the employees' gross salary. Civil servants contribute to the Public Officers Superannuation Fund, where contribution rates of 6 percent for the employee and 8.4 percent for the employer apply.

17. Superannuation funds are subject to income tax. The corporate income tax rate for authorized superannuation funds was reduced from 30 percent to 25 percent in 2004 . This is expected to increase domestic savings, and boost member returns and benefits over time. To further encourage savings, the government also introduced concessional taxation arrangements in 2004, allowing the retention of funds in the newly established Retirement Savings Accounts 
(RSAs) up to a maximum of K 100,000. Under the new arrangement, employees exiting a superannuation fund can voluntarily transfer their savings to RSAs. These savings can be drawn down on a periodic basis free of income tax, providing an income stream in retirement. Draw-down rules limit the rate at which monies can be withdrawn in order to protect savings from dissipation. The earnings of RSAs are also free from income tax, subject to the maximum draw-down rules.

\section{The 2004 Budget also introduced concessional tax rates for employer} contributions and fund earnings at the benefit stage in accordance with Table IV.3. Previously, only employees who have been with a fund for more than 15 years benefited from the concessional tax rate of 2 percent.

Table IV.3. Tax Rates Applying to Superannuation Earnings

\begin{tabular}{lc}
\hline Years of contribution & Marginal tax rate (percent) \\
\hline Less than 5 years & Income tax rates as shown in Table IV.1 \\
At least 5 years but less than 10 years & 15 percent \\
At least 10 years but less than 15 years & 8 percent \\
15 years or more & 2 percent
\end{tabular}

\section{B. Indirect Taxation}

\section{Goods and Services Tax}

19. The goods and services tax (GST) has a uniform tax rate of $\mathbf{1 0}$ percent on the price of goods sold by a business, with zero-rated exports, including for the mining and petroleum sectors. Exempted goods and services are mainly medical services, financial services, education services and supplies, fine metals and public transportation fees. GST is levied on all imported goods, with the exception of imports by aid donors and diplomatic missions and for the mining and petroleum sectors. All businesses with an expected turnover in excess of K 100,000 must register for GST. Registration for other businesses is voluntary.

20. From 2004, inland GST collections (net of refunds) are distributed between national government and provinces on the basis of 40 percent to the national government and 60 percent to provincial governments. ${ }^{2}$ Each provincial share of the net inland collection is calculated in accordance with the formula set out in the GST Revenue Distribution Act. Up until 31 December 2006 these distributions were based on an estimate of the revenue to be received in the year. For 2007 and future years the distribution will be based on the actual net revenue received two years previously, provided the distribution is no less than the actual distribution to a province in 2006.

\footnotetext{
${ }^{2}$ Except for Bougainville where the distribution is on the basis of 70 percent to the national government and 30 percent to the province.
} 


\section{Excise Taxes}

21. Excise taxes are applied to alcoholic beverages (beer, wine, and spirits), cigarettes, other manufactured tobacco products, and fuels. Since the 1999 tax and tariff reform, excise taxes also apply to a few products that were previously protected by high tariffs, such as motor vehicles and audio-visual electronic equipment. The excise rates for alcohol and tobacco products were indexed by 4 percent every six months from May 1, 2003. However, the 2004 Budget froze the indexation for 12 months until November 31, 2004. From December 1, 2004, the excise indexation for alcohol and tobacco products resumed at 2.5 percent. From December 1, 2005, the excise indexation for alcohol and tobacco products became the lesser of 2.5 percent or the increase in the Consumer Price Index every six months, with the rates applying from December $1^{\text {st }} 2008$ shown in Table IV.4.

22. From the beginning of 2004, an excise duty exemption was granted to business and individual importing tractors for use in agricultural and forestry work as well as pedestrian controlled tractors. The excise rate was reduced from 10 percent to 0 percent.

Table IV.4. Excise Tax Rates

\begin{tabular}{ll}
\hline Commodity & Excise Rate \\
\hline Alcohol (per liter of alcohol) & \\
Beer (dependent on strength) & $\mathrm{K} 34.52-59.73$ (new rates from end-Nov. 2007) \\
Wine and spirits & $\mathrm{K} 63.43-68.07$ \\
Tobacco products & $\mathrm{K} 150.90$ \\
Cigars (per Kg) & $\mathrm{K} 150.90$ \\
Regular cigarettes (per 1,000) & $\mathrm{K} 75.45$ \\
Spear no filter (per 1,000) & $\mathrm{K} 94.16$ \\
Spear filter (per 1,000) & $\mathrm{K} 50.30$ \\
Smoking tobacco (leaf, per kg.) Coarse & $\mathrm{K} 29.18$ \\
Shredded Tobacco (per Kg) & $\mathrm{K} 50.30$ \\
Others & $\mathrm{K} 0.61$ per liter \\
Petroleum products & Abolished from 1 January 2007 \\
Gasoline & $\mathrm{K} 0.06$ per liter (K 0.03 for commercial fishing vessels) \\
Aviation gasoline & K0.02 per liter \\
Diesel & K 0.30 per liter until 31 December 2008 (trialed in 2007). \\
& Policy to be reviewed in 2009 Budget. \\
Jet A1- & \\
Zoom (Gasoline and oil mix) & 40 percent \\
Other & \\
Pearls, diamonds, and some metals & 30 percent \\
Drying, dictating and answering & $0-110$ percent \\
machines, microwave ovens & 60 percent \\
Motor vehicles & 50 percent \\
Arms &
\end{tabular}




\section{Import Duties}

\section{The Harmonized Commodity Description and Coding System (HS Tariff) was}

adopted in January 1991. The tariff classifications will be revised in 2008 to reflect the latest international standards. Papua New Guinea became a member of the World Customs Organization in 1998, and is implementing the WTO agreement on Customs Valuations. Papua New Guinea bound its entire tariff schedule during the Uruguay Round. A seven-year tariff reform program (TRP) commenced in July 1999, rationalizing the tariff structure and setting a schedule for the phased reductions of tariffs. Under the TRP, tariff rates were reduced to the current rates of 15, 25, and 40 percent in January 2006. A review of the TRP was concluded in 2007 and recommendations will be considered for implementation in the 2009 budget. Domestic sugar production is protected with a specific 70 percent tariff, which will be maintained until the end of 2010 while domestic canned mackerel production is protected with a specific 20 percent tariff, which will be maintained until the end of 2010 .

\section{Preferential import tariff arrangements exist with members of the Melanesian Spearhead Group, and a bilateral arrangement with Fiji.}

Table IV.5. Tariff Rates (in percent)

\begin{tabular}{lrc}
\hline Tariff Category & Current Tariff Rate & Tariff Rate Prior to July 1999 \\
\hline Duty free & 0 & 0 \\
Input rate & Abolished & 5 \\
Basic rate & Abolished & 11 \\
Intermediate rate & 15 & 40 \\
Protective rate & 25 & 55 \\
Prohibitive rate & 40 & $75-125$ \\
\hline
\end{tabular}

The descriptions of the tariff categories are as follows:

- Duty free items: more than three-fourths of all lines fall into this category.

- Intermediate rate items: intermediate goods.

- Protective rate items: goods that are produced, or potentially can be produced, in Papua New Guinea and are seen as requiring a level of protection.

- Prohibitive rate items: these include fresh vegetables, fruits and nuts (whether or not preserved), beer, cigarettes and cigars, veneer and plywood, articles of jewelry and pearls, prefabricated buildings and sugar. Tariffs for some of these products (plywood, and veneer sheets) will be higher than the prohibitive rate during the phased reduction, but set at the general prohibitive rate in 2006. There is a specific tariff on beer, spirits, cigarettes, matches, shelled birds' eggs and certain tobacco products. 


\section{Import Levy}

25. In 2004, a temporary levy of 2.0 percent was imposed on imports, except imports by the mining and petroleum sectors, by churches and charitable groups, and pharmaceuticals and medical goods. The levy was operative until December 31, 2004 only.

\section{Export Duties}

26. Export duties are levied only on unprocessed logs, sandalwood, crocodile skins and mineral ores; the duty varies depending on the product. Export duties are calculated on an f.o.b. basis and are payable before shipment. A pre-shipment inspection system on the export of round logs has been supplied by a private contractor since late 1994. Up until 31 December 2006 the log export duty was imposed on a progressive rate scale. A new forestry revenue sharing arrangement was introduced in 2007, which lowered the export duty on logs from 35 percent to 28.5 percent. Landowners are intended to benefit from this change as the export tax reduction is designed to be offset by the payment of an export development levy of K8 per cubic meter. Plantation logs are exempt from export duty. Crocodile skins are charged an export tax set at 5 percent, and sandalwood is charged at a rate of 15 percent.

\section{Other Taxes}

27. Gaming machine tax (Tax on Pokies) was introduced in October 1996 as a general revenue measure, and last increased by the Gaming Machine (Amendment) Act of 2002. In May 2007, the new Gaming Control Act amended the distribution of the turnover of gaming machines to all stakeholders as shown in Table IV.6.

Table IV.6. Distribution of Poker Machine Tax

\begin{tabular}{lcc}
\hline & $\begin{array}{l}\text { Share (Percent) } \\
\text { As Per Gaming } \\
\text { Machine } \\
\text { (Amendment) } \\
\text { Act of 2002 }\end{array}$ & $\begin{array}{l}\text { Share (Percent) } \\
\text { As Per the } \\
\text { Gaming Control } \\
\text { Act 2007 }\end{array}$ \\
\hline National government & 74 & 46 \\
Operators & 4 & 10 \\
Site owners & 22 & 25 \\
Gaming Board & Not Applicable & 5 \\
Community Benefit Fund Account & Not Applicable & 14 \\
\hline
\end{tabular}

28. The 2008 budget abolished stamp duty on a number of items. Stamp duties are imposed by the national government on the execution of certain documents. The rates vary by type of document. Stamp duty is abolished on the following items from January 1, 2008: loan agreements or contracts; loan securities, mortgages and foreign securities, hire and credit 
purchase agreements; bills of lading; and certificates of incorporation. Stamp duty on insurance contracts and debits tax will also be abolished from April 1, 2008. ${ }^{3}$

29. Departure tax of K 30 is payable by all persons departing Papua New Guinea. Departing international passengers also pay a K 30 terminal facility charge to the Civil Aviation Authority.

30. Land tax may be imposed by provincial governments although this tax is difficult to implement and collect.

\section{Tax Concessions and incentives}

31. To encourage investment a number of tax concessions are offered. Sector specific concessions in the agriculture, forestry, fisheries, manufacturing, petroleum, and mining sectors are noted above. In addition, and to try to avoid previous practices where ad hoc concessions were granted in particular project agreements, generally applicable tax concessions have been introduced. These include:

- A research and development incentive, where a 150 percent income tax deduction is allowed for expenditure on research and development;

- $\quad$ A double deduction for staff training costs, which allows a double deduction against company income tax for the payment of salaries and wages of registered apprentices or other employees attending full-time training at a Government training institute or prescribed tertiary institution;

- A duty drawback, which is a rebate paid to exporting manufacturers when they export goods equal to the amount of duty already paid on new materials;

- $\quad$ An export sales exemption, which exempts profits from export sales for the first three years and income from increases in exports for the following four years; and

- $\quad$ Accelerated and flexible depreciation, which allows for capital assets to be written off at a faster rate than their effective lives. New industrial plant is eligible for increased depreciation up to 100 percent of cost. The taxpayer may elect the amount to be claimed in any year, but not so as to create a loss. To qualify, the plant must have a life exceeding five years, and can be used by the taxpayer or any other person.

32. The Government has over successive budgets estimated and reported on the size of its tax concessions. Table IV.7 shows the estimated size of the tax concessions for the past five years. Details of the amounts forgone are set out in budget documents.

\footnotetext{
${ }^{3}$ The debit tax was introduced during 2003, and applied to withdrawals of K50 and over from financial institutions.
} 
Table IV.7. Estimated revenue foregone due to tax concessions

\begin{tabular}{|l|c|c|c|c|c|}
\hline Year & $\mathbf{2 0 0 2}$ & $\mathbf{2 0 0 3}$ & $\mathbf{2 0 0 4}$ & $\mathbf{2 0 0 5}$ & $\mathbf{2 0 0 6}$ \\
\hline Amount & 34.4 & 76.7 & 34.9 & 37.7 & 30 \\
\hline
\end{tabular}

Source: Department of Treasury, 2008 Budget documents. 
STATISTICAL APPENDIX

Table 1. Papua New Guinea: GDP by Sector at Current Market Prices, 2002-06

\begin{tabular}{|c|c|c|c|c|c|}
\hline & 2002 & 2003 & 2004 & 2005 & 2006 \\
\hline & \multicolumn{5}{|c|}{ (In millions of kina) } \\
\hline Nominal GDP 1/ & 11,656 & 12,567 & 12,652 & 15,263 & 17,051 \\
\hline Mineral & 2,150 & 2,252 & 2,391 & 3,555 & 4,686 \\
\hline Nonmineral & 9,506 & 10,316 & 10,261 & 11,708 & 12,365 \\
\hline Of which: Nonagricultural & 5,078 & 5,496 & 5,710 & 6,024 & 6,542 \\
\hline Agriculture, forestry and fishing & 4,428 & 4,819 & 4,551 & 5,684 & 5,823 \\
\hline Mining, quarrying, and petroleum & 2,150 & 2,252 & 2,391 & 3,555 & 4,686 \\
\hline Manufacturing & 729 & 821 & 848 & 943 & 1,000 \\
\hline Electricity, gas and water & 194 & 229 & 264 & 284 & 302 \\
\hline Construction & 996 & 1,129 & 1,177 & 1,246 & 1,437 \\
\hline Wholesale and retail trade & 746 & 850 & 891 & 945 & 1,021 \\
\hline Transport, storage and communication & 268 & 294 & 305 & 317 & 326 \\
\hline Financing, insurance, real estate and business services & 407 & 423 & 415 & 449 & 502 \\
\hline Less: Imputed bank service charge & 185 & 188 & 196 & 215 & 230 \\
\hline Community, social and personal services & 1,352 & 1,403 & 1,395 & 1,427 & 1,521 \\
\hline Import duties & 575 & 539 & 615 & 632 & 666 \\
\hline \multirow[t]{2}{*}{ Less: Subsidies } & 3 & 3 & 3 & 3 & 3 \\
\hline & \multicolumn{5}{|c|}{ (In percent of GDP) } \\
\hline \multicolumn{6}{|l|}{ Memorandum items: } \\
\hline Nominal GDP & 100.0 & 100.0 & 100.0 & 100.0 & 100.0 \\
\hline Mineral & 18.4 & 17.9 & 18.9 & 23.3 & 27.5 \\
\hline Nonmineral & 81.6 & 82.1 & 81.1 & 76.7 & 72.5 \\
\hline Of which: Nonagricultural & 43.6 & 43.7 & 45.1 & 39.5 & 38.4 \\
\hline Agriculture, forestry and fishing & 38.0 & 38.3 & 36.0 & 37.2 & 34.2 \\
\hline Mining, quarrying, and petroleum & 18.4 & 17.9 & 18.9 & 23.3 & 27.5 \\
\hline Manufacturing & 6.3 & 6.5 & 6.7 & 6.2 & 5.9 \\
\hline Electricity, gas and water & 1.7 & 1.8 & 2.1 & 1.9 & 1.8 \\
\hline Construction & 8.5 & 9.0 & 9.3 & 8.2 & 8.4 \\
\hline Wholesale and retail trade & 6.4 & 6.8 & 7.0 & 6.2 & 6.0 \\
\hline Transport, storage and communication & 2.3 & 2.3 & 2.4 & 2.1 & 1.9 \\
\hline Financing, insurance, real estate and business services & 3.5 & 3.4 & 3.3 & 2.9 & 2.9 \\
\hline Less: Imputed bank service charge & 1.6 & 1.5 & 1.5 & 1.4 & 1.3 \\
\hline Community, social and personal services & 11.6 & 11.2 & 11.0 & 9.4 & 8.9 \\
\hline Import duties & 4.9 & 4.3 & 4.9 & 4.1 & 3.9 \\
\hline Less: Subsidies & 0.0 & 0.0 & 0.0 & 0.0 & 0.0 \\
\hline
\end{tabular}

Sources: Data provided by the National Statistical Office through 2004; Treasury Department estimates for 2005 and 2006.

1/ Sum of industries less imputed bank service charge, plus import duties less subsidies. 
Table 2. Papua New Guinea: GDP by Sector at 1998 Constant Prices, 2002-06

\begin{tabular}{|c|c|c|c|c|c|}
\hline & 2002 & 2003 & 2004 & 2005 & 2006 \\
\hline & \multicolumn{5}{|c|}{ (In millions of 1998 kina) } \\
\hline Real GDP 1/ & 7,728 & 7,896 & 8,111 & 8,383 & 8,598 \\
\hline Mineral & 943 & 969 & 972 & 1,020 & 959 \\
\hline Nonmineral & 6,786 & 6,927 & 7,139 & 7,364 & 7,638 \\
\hline Of which: Nonagricultural & 3,997 & 3,999 & 4,077 & 4,246 & 4,500 \\
\hline Agriculture, forestry and fishing & 2,789 & 2,927 & 3,062 & 3,118 & 3,139 \\
\hline Mining, quarrying, and petroleum & 943 & 969 & 972 & 1,020 & 959 \\
\hline Manufacturing & 560 & 587 & 600 & 660 & 694 \\
\hline Electricity, gas and water & 107 & 121 & 126 & 130 & 134 \\
\hline Construction & 805 & 849 & 876 & 918 & 1,028 \\
\hline Wholesale and retail trade & 526 & 539 & 556 & 579 & 613 \\
\hline Transport, storage and communication & 206 & 210 & 215 & 222 & 233 \\
\hline Financing, insurance, real estate and business services & 324 & 313 & 303 & 318 & 345 \\
\hline Less: Imputed bank service charge & 149 & 153 & 158 & 162 & 167 \\
\hline Community, social and personal services & 1,174 & 1,133 & 1,106 & 1,124 & 1,152 \\
\hline Import duties & 448 & 403 & 455 & 461 & 471 \\
\hline \multirow[t]{2}{*}{ Less: Subsidies } & 2 & 2 & 2 & 2 & 2 \\
\hline & \multicolumn{5}{|c|}{ (Annual percentage change) } \\
\hline \multicolumn{6}{|l|}{ Memorandum items: } \\
\hline Real GDP & -0.2 & 2.2 & 2.7 & 3.4 & 2.6 \\
\hline Mineral & -15.9 & 2.8 & 0.3 & 5.0 & -5.9 \\
\hline Nonmineral & 2.5 & 2.1 & 3.1 & 3.1 & 3.7 \\
\hline Of which: Nonagricultural & 7.7 & 0.1 & 1.9 & 4.2 & 6.0 \\
\hline Agriculture, forestry and fishing & -4.1 & 5.0 & 4.6 & 1.8 & 0.7 \\
\hline Mining, quarrying, and petroleum & -15.9 & 2.8 & 0.3 & 5.0 & -5.9 \\
\hline Manufacturing & -5.8 & 4.8 & 2.3 & 10.0 & 5.0 \\
\hline Electricity, gas and water & -0.4 & 13.4 & 4.3 & 2.7 & 3.0 \\
\hline Construction & 34.0 & 5.4 & 3.2 & 4.8 & 12.0 \\
\hline Wholesale and retail trade & 22.7 & 2.6 & 3.2 & 4.0 & 6.0 \\
\hline Transport, storage and communication & -2.0 & 2.1 & 2.6 & 3.0 & 5.0 \\
\hline Financing, insurance, real estate and business services & -5.5 & -3.4 & -3.4 & 5.0 & 8.5 \\
\hline Less: Imputed bank service charge & -1.9 & 2.9 & 2.9 & 3.0 & 3.0 \\
\hline Community, social and personal services & 2.9 & -3.5 & -2.4 & 1.7 & 2.5 \\
\hline Import duties & 1.6 & -10.1 & 12.9 & 1.3 & 2.3 \\
\hline Less: Subsidies & 0.0 & 0.0 & 0.0 & 0.0 & 0.0 \\
\hline
\end{tabular}

Sources: Data provided by the National Statistical Office through 2004; Treasury Department estimates for 2005 and 2006.

1/ Sum of industries less imputed bank service charge, plus import duties less subsidies. 
Table 3. Papua New Guinea: Production of Major Commodities, 2002-05

\begin{tabular}{|c|c|c|c|c|}
\hline & 2002 & 2003 & 2004 & 2005 \\
\hline \multicolumn{5}{|l|}{ Production volumes } \\
\hline Crude oil (millions of barrels) & 15.4 & 15.0 & 12.6 & 13.3 \\
\hline Copper (thousands of tonnes) & 170.1 & 230.6 & 173.9 & 226.1 \\
\hline Gold (tonnes) & 59.1 & 68.4 & 67.3 & 70.5 \\
\hline Silver (tonnes) & 11.5 & 12.7 & 13.6 & 16.0 \\
\hline Cocoa (thousands of tonnes) & 34.9 & 40.3 & 41.5 & 44.2 \\
\hline Coffee (thousands of tonnes) & 63.1 & 68.8 & 63.0 & 72.1 \\
\hline Tea (thousands of tonnes) & 5.2 & 6.6 & 8.1 & 6.9 \\
\hline Copra (thousands of tonnes) & 15.8 & 8.4 & 19.2 & 22.3 \\
\hline Copra oil (thousands of tonnes) & 28.2 & 47.7 & 45.1 & 54.4 \\
\hline Palm oil (thousands of tonnes) & 323.9 & 326.9 & 339.0 & 345.8 \\
\hline Rubber (thousands of tonnes) & 3.8 & 4.2 & 3.8 & 4.8 \\
\hline Logs (millions of cubic meters) & 1.8 & 2.0 & 2.0 & 2.3 \\
\hline & \multicolumn{4}{|c|}{ (In millions of kina) } \\
\hline \multicolumn{5}{|l|}{ Production values } \\
\hline Crude oil & 1431 & 1632 & 1652 & 2283 \\
\hline Copper & 1019 & 1415 & 1544 & 2498 \\
\hline Gold & 2295 & 2811 & 2780 & 2834 \\
\hline Silver & 29 & 32 & 32 & 37 \\
\hline Cocoa & 226 & 258 & 218 & 199 \\
\hline Coffee & 277 & 299 & 284 & 471 \\
\hline Tea & 18 & 19 & 23 & 20 \\
\hline Copra & 11 & 7 & 17 & 17 \\
\hline Copra oil & 33 & 67 & 81 & 94 \\
\hline Palm oil & 390 & 421 & 439 & 391 \\
\hline Rubber & 9 & 12 & 14 & 18 \\
\hline Logs & 366 & 370 & 356 & 405 \\
\hline
\end{tabular}

Source: Data provided by the Papua New Guinea authorities. 
Table 4. Papua New Guinea: Employment by Sector, 2003-June 2007

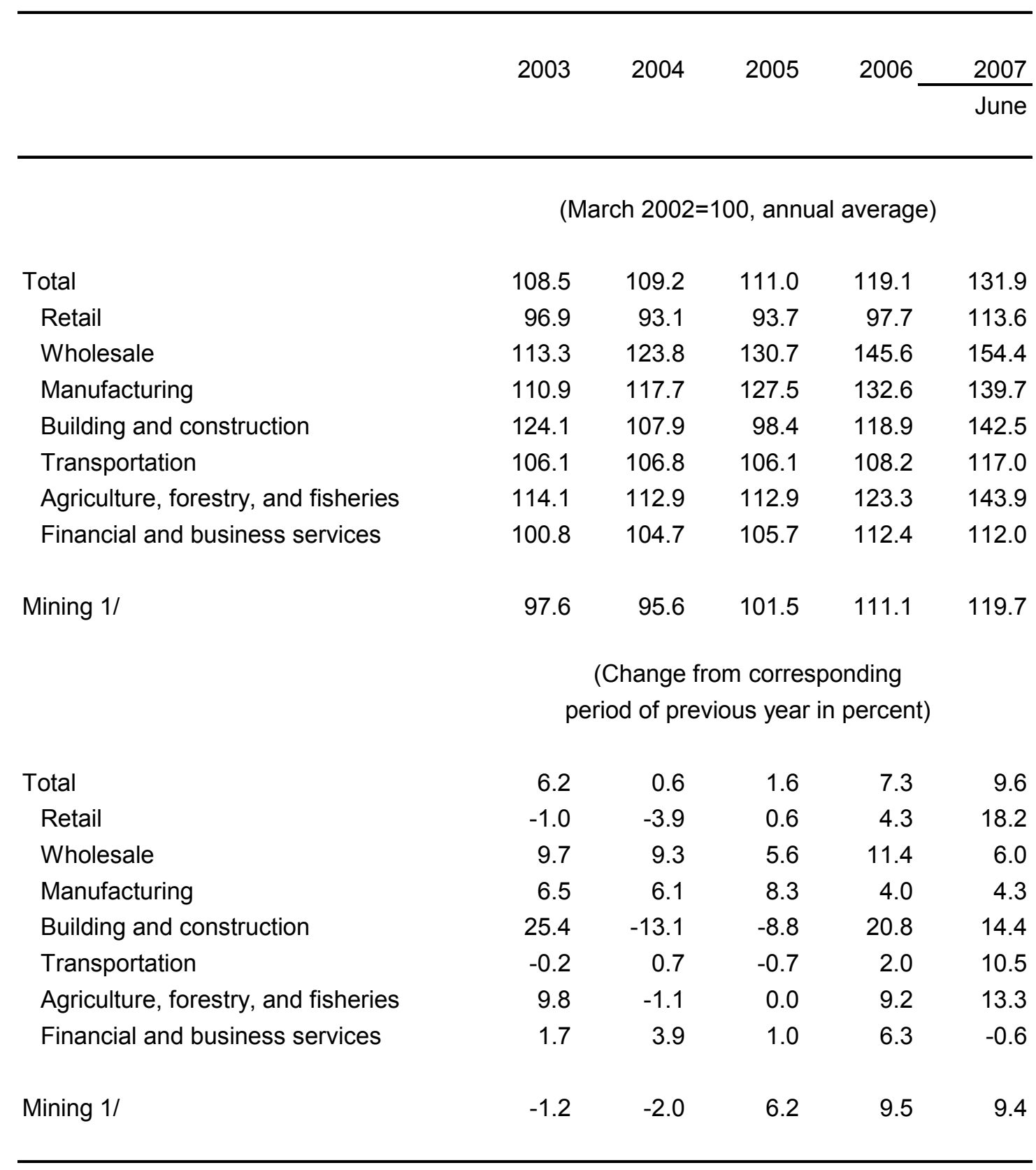

Source: Bank of Papua New Guinea, Quarterly Economic Bulletin.

1/ Not included in overall index; excludes subcontractors. 
Table 5. Papua New Guinea: Consumer Price Index by Expenditure Group, 2002-June 2007

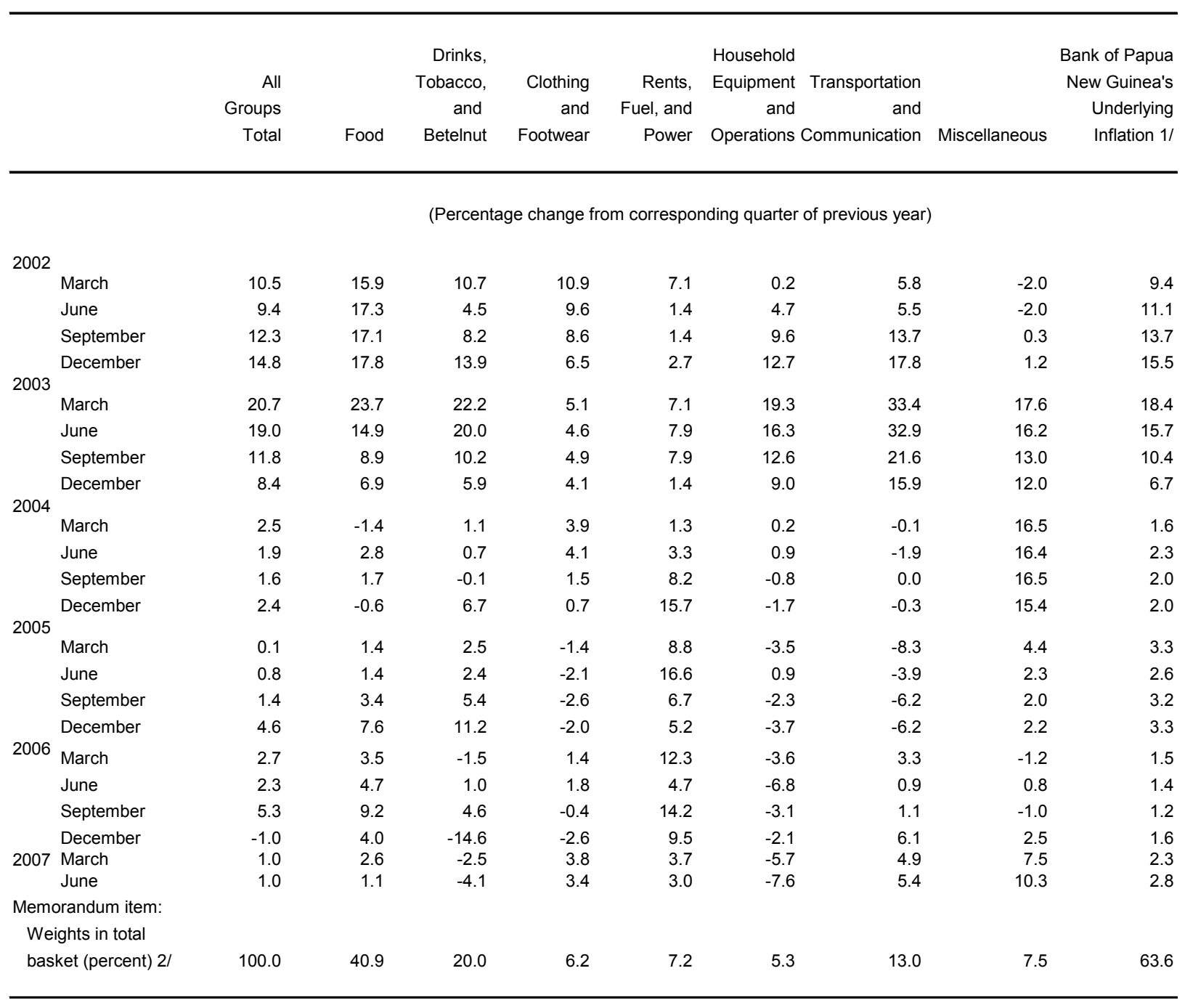

Sources: Consumer Price Index, National Statistical Office; and Bank of Papua New Guinea's Quarterly Economic Bulletin.

1/ Excluding food and goods and services subject to administered prices.

2/ Weights are based on the 1977 expenditure survey. 
Table 6a. Papua New Guinea: Central Government Budget, 2003-07

(In millions of kina)

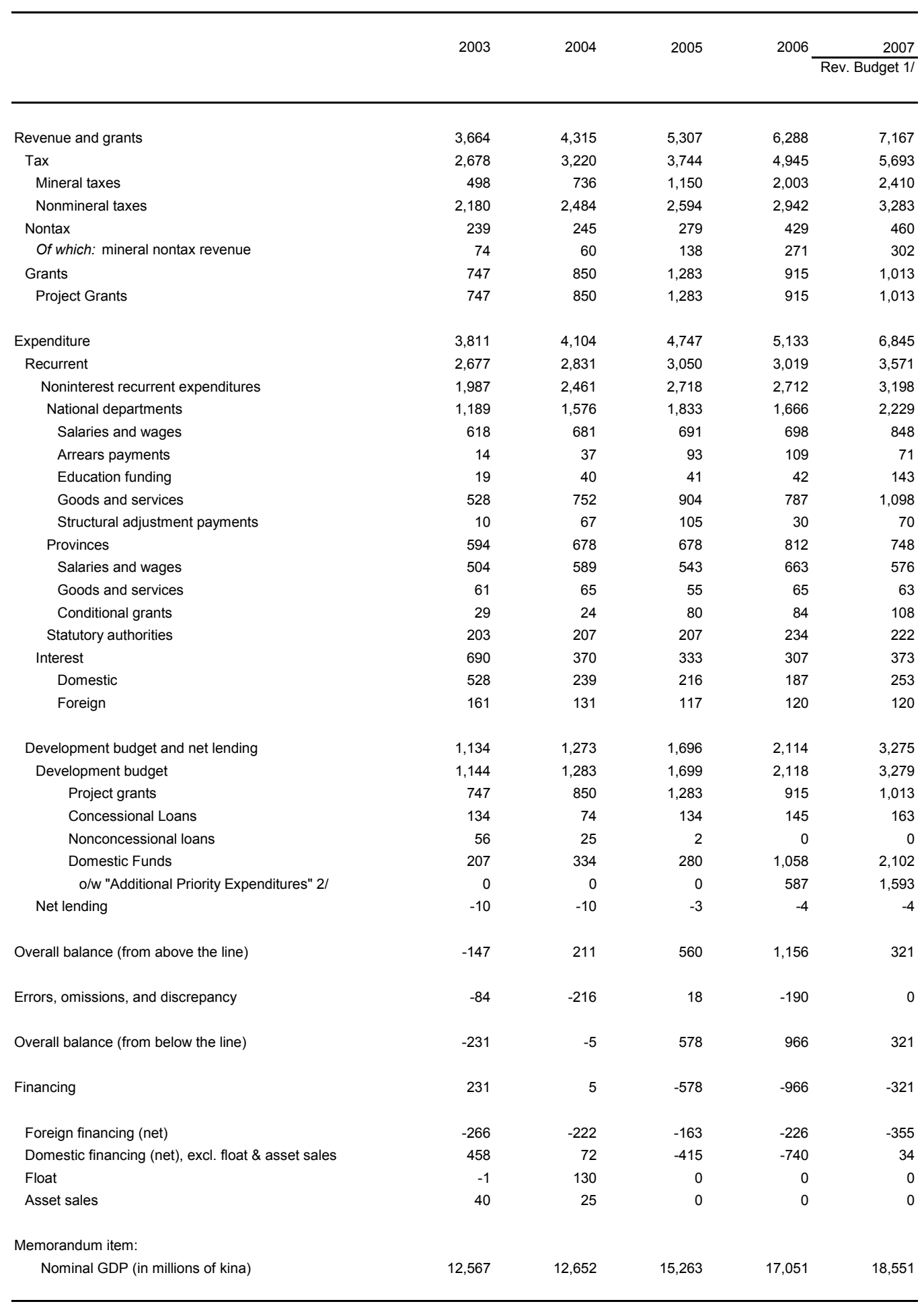

Sources: Data provided by the Papua New Guinea authorities; and Fund staff estimates.

1/ Includes Supplementary budget passed in November 2007

2/ For 2005-07 the government classified earmarked funds that are transferred to government trust funds as expenditure.

Under the staff's cash presentation, the outturns for 2005-06 reflect a cash accounting basis (consistent with Government

Finance Statistics) where expenditure occurs only when money is disbursed from these trust funds. 
Table 6b. Papua New Guinea: Central Government Budget, 2003-07

(In percent of GDP)

\begin{tabular}{|c|c|c|c|c|c|}
\hline & 2003 & 2004 & 2005 & 2006 & 2007 \\
\hline Revenue and grants & 29.2 & 34.1 & 34.8 & 36.9 & 38.6 \\
\hline Tax & 21.3 & 25.4 & 24.5 & 29.0 & 30.7 \\
\hline Mineral taxes & 4.0 & 5.8 & 7.5 & 11.7 & 13.0 \\
\hline Nonmineral taxes & 17.3 & 19.6 & 17.0 & 17.3 & 17.7 \\
\hline Nontax & 1.9 & 1.9 & 1.8 & 2.5 & 2.5 \\
\hline Of which: mineral nontax revenue & 0.6 & 0.5 & 0.9 & 1.6 & 1.6 \\
\hline Grants & 5.9 & 6.7 & 8.4 & 5.4 & 5.5 \\
\hline Project Grants & 5.9 & 6.7 & 8.4 & 5.4 & 5.5 \\
\hline Expenditure & 30.3 & 32.4 & 31.1 & 30.1 & 36.9 \\
\hline Recurrent & 21.3 & 22.4 & 20.0 & 17.7 & 19.2 \\
\hline Noninterest recurrent expenditures & 15.8 & 19.5 & 17.8 & 15.9 & 17.2 \\
\hline National departments & 9.5 & 12.5 & 12.0 & 9.8 & 12.0 \\
\hline Salaries and wages & 4.9 & 5.4 & 4.5 & 4.1 & 4.6 \\
\hline Arrears payments & 0.1 & 0.3 & 0.6 & 0.6 & 0.4 \\
\hline Education funding & 0.2 & 0.3 & 0.3 & 0.2 & 0.8 \\
\hline Goods and services & 4.2 & 5.9 & 5.9 & 4.6 & 5.9 \\
\hline Structural adjustment payments & 0.1 & 0.5 & 0.7 & 0.2 & 0.4 \\
\hline Provinces & 4.7 & 5.4 & 4.4 & 4.8 & 4.0 \\
\hline Salaries and wages & 4.0 & 4.7 & 3.6 & 3.9 & 3.1 \\
\hline Goods and services & 0.5 & 0.5 & 0.4 & 0.4 & 0.3 \\
\hline Conditional grants & 0.2 & 0.2 & 0.5 & 0.5 & 0.6 \\
\hline Statutory authorities & 1.6 & 1.6 & 1.4 & 1.4 & 1.2 \\
\hline Interest & 5.5 & 2.9 & 2.2 & 1.8 & 2.0 \\
\hline Domestic & 4.2 & 1.9 & 1.4 & 1.1 & 1.4 \\
\hline Foreign & 1.3 & 1.0 & 0.8 & 0.7 & 0.6 \\
\hline Development budget and net lending & 9.0 & 10.1 & 11.1 & 12.4 & 17.7 \\
\hline Development budget & 9.1 & 10.1 & 11.1 & 12.4 & 17.7 \\
\hline Project grants & 5.9 & 6.7 & 8.4 & 5.4 & 5.5 \\
\hline Concessional Loans & 1.1 & 0.6 & 0.9 & 0.9 & 0.9 \\
\hline Nonconcessional loans & 0.4 & 0.2 & 0.0 & 0.0 & 0.0 \\
\hline Domestic Funds & 1.6 & 2.6 & 1.8 & 6.2 & 11.3 \\
\hline o/w "Additional Priority Expenditures" 2/ & 0.0 & 0.0 & 0.0 & 3.4 & 8.6 \\
\hline Net lending & -0.1 & -0.1 & 0.0 & 0.0 & 0.0 \\
\hline Overall balance (from above the line) & -1.2 & 1.7 & 3.7 & 6.8 & 1.7 \\
\hline Errors, omissions, and discrepancy & -0.7 & -1.7 & 0.1 & -1.1 & 0.0 \\
\hline Overall balance (from below the line) & -1.8 & 0.0 & 3.8 & 5.7 & 1.7 \\
\hline Financing & 1.8 & 0.0 & -3.8 & -5.7 & -1.7 \\
\hline Foreign financing (net) & -2.1 & -1.8 & -1.1 & -1.3 & -1.9 \\
\hline Domestic financing (net), excl. float \& asset sales & 3.6 & 0.6 & -2.7 & -4.3 & 0.2 \\
\hline Float & 0.0 & 1.0 & 0.0 & 0.0 & 0.0 \\
\hline Asset sales & 0.3 & 0.2 & 0.0 & 0.0 & 0.0 \\
\hline \multicolumn{6}{|l|}{ Memorandum items: } \\
\hline Nominal GDP (in millions of kina) & 12,567 & 12,652 & 15,263 & 17,051 & 18,551 \\
\hline Nonmineral fiscal balance & -6.4 & -6.3 & -4.7 & -7.7 & -12.9 \\
\hline
\end{tabular}

Sources: Data provided by the Papua New Guinea authorities; and Fund staff estimates.

1/ Includes Supplementary budget passed in November 2007

2/ For 2005-07 the government classified earmarked funds that are transferred to government trust funds as expenditure. Under the staff's cash presentation, the outturns for 2005-06 reflect a cash accounting basis (consistent with Government Finance Statistics) where expenditure occurs only when money is disbursed from these trust funds. 
Table 7. Papua New Guinea: Central Government Revenue and Grants, 2003-07

(In millions of kina)

\begin{tabular}{|c|c|c|c|c|c|}
\hline & 2003 & 2004 & 2005 & \multicolumn{2}{|c|}{$\overline{\text { Rev. Budget 1/ }}$} \\
\hline Total revenue and grants & 3,664 & 4,315 & 5,307 & 6,288 & 7,167 \\
\hline Tax revenue & 2,678 & 3,220 & 3,744 & 4,945 & 5,693 \\
\hline Taxes on income and profit & 1,786 & 2,223 & 2,771 & 3,824 & 4,387 \\
\hline Personal tax & 758 & 827 & 841 & 907 & 994 \\
\hline Company tax & 335 & 437 & 517 & 551 & 633 \\
\hline Dividend withholding tax & 117 & 123 & 155 & 201 & 183 \\
\hline Mineral and petroleum taxes & 396 & 634 & 1,077 & 1,947 & 2,362 \\
\hline Other direct & 55 & 79 & 72 & 92 & 95 \\
\hline Interest withholding tax & 41 & 33 & 18 & 22 & 19 \\
\hline Gaming tax & 83 & 91 & 92 & 104 & 100 \\
\hline Indirect taxes & 892 & 997 & 973 & 1,121 & 1,307 \\
\hline Excise tax & 175 & 203 & 256 & 324 & 336 \\
\hline VAT plus mining levy & 414 & 417 & 399 & 457 & 602 \\
\hline VAT & 312 & 316 & 326 & 401 & 554 \\
\hline Mining levy & 102 & 101 & 73 & 56 & 48 \\
\hline Other indirect & 1 & 1 & 2 & 3 & 2 \\
\hline Taxes on international trade & 302 & 376 & 316 & 337 & 366 \\
\hline Import duties & 74 & 151 & 101 & 90 & 124 \\
\hline Export duties (logs) & 112 & 102 & 136 & 163 & 153 \\
\hline Import excises & 110 & 123 & 79 & 84 & 89 \\
\hline Import levy & 7 & 0 & 0 & 0 & 0 \\
\hline Nontax revenue & 239 & 245 & 279 & 429 & 460 \\
\hline Property income & 160 & 165 & 188 & 339 & 375 \\
\hline Dividends & 86 & 105 & 50 & 68 & 74 \\
\hline Mining and petroleum & 74 & 60 & 138 & 271 & 302 \\
\hline Interest and fees & 4 & 3 & 1 & 1 & 3 \\
\hline Other & 75 & 78 & 91 & 89 & 82 \\
\hline Asset sales costs & 0 & 0 & 0 & 0 & 0 \\
\hline Foreign grants & 747 & 850 & 1,283 & 915 & 1,013 \\
\hline Project grants & 747 & 850 & 1,283 & 915 & 1,013 \\
\hline
\end{tabular}

Sources: Data provided by the Papua New Guinea authorities; and Fund staff estimates.

1/ Includes Supplementary budget passed in November 2007. 
Table 8. Papua New Guinea: Central Government Fiscal Financing, 2003-07

(In millions of kina)

\begin{tabular}{|c|c|c|c|c|c|}
\hline & 2003 & 2004 & 2005 & 2006 & $\frac{2007}{\text { get } 1 /}$ \\
\hline Total Financing & 231 & 5 & -578 & -966 & -321 \\
\hline Foreign financing (net) & -266 & -222 & -163 & -226 & -355 \\
\hline New borrowing & 190 & 181 & 136 & 145 & 163 \\
\hline Project loans & 190 & 99 & 137 & 153 & 163 \\
\hline Concessional financing & 0 & 82 & 0 & 0 & 0 \\
\hline Amortization & 456 & 403 & 300 & 371 & 518 \\
\hline Domestic financing (net), excl. float $\&$ asset sales & 458 & 72 & -415 & -740 & 34 \\
\hline \multicolumn{6}{|l|}{ Bank of Papua New Guinea } \\
\hline Net credit to central government & -306 & -270 & -512 & -121 & $\ldots$ \\
\hline Securities & -310 & -180 & 30 & 37 & $\ldots$ \\
\hline Treasury bills & -291 & -180 & 0 & 0 & $\ldots$ \\
\hline Inscribed stock & -19 & 0 & 30 & 37 & $\ldots$ \\
\hline Temporary advance & -4 & -91 & 0 & -1 & $\ldots$ \\
\hline Deposits & 7 & 1 & -542 & -157 & $\ldots$ \\
\hline \multicolumn{6}{|l|}{ Commercial Banks } \\
\hline Net credit to central government & 193 & 310 & 332 & -27 & $\ldots$ \\
\hline Securities & 212 & 346 & 419 & 228 & $\ldots$ \\
\hline Treasury bills & 232 & -90 & -40 & -106 & $\ldots$ \\
\hline Inscribed stock & -20 & 436 & 459 & 335 & $\ldots$ \\
\hline Loans & -1 & -1 & 0 & 10 & 0 \\
\hline Deposits & -18 & -34 & -87 & -266 & $\ldots$ \\
\hline \multicolumn{6}{|l|}{ Nonbanks } \\
\hline Net credit to central government & 571 & 31 & -235 & -592 & $\ldots$ \\
\hline Securities & 575 & 39 & -219 & -592 & $\ldots$ \\
\hline Treasury bills & 645 & -249 & -400 & -539 & $\ldots$ \\
\hline Inscribed stock & -70 & 288 & 181 & -53 & $\ldots$ \\
\hline Loans & -5 & -7 & -16 & 0 & 0 \\
\hline Float & -1 & 130 & 0 & 0 & 0 \\
\hline Asset sales & 40 & 25 & 0 & 0 & 0 \\
\hline
\end{tabular}

Sources: Data provided by the Papua New Guinea authorities; and Fund staff estimates.

1/ Includes Supplementary budget passed in November 2007. 
Table 9: Papua New Guinea: Central Government Domestic Debt, 2003-September 2007

(In millions of kina; end of period)

\begin{tabular}{|c|c|c|c|c|c|c|}
\hline & \multirow[t]{2}{*}{2003} & \multirow[t]{2}{*}{2004} & \multirow[t]{2}{*}{2005} & \multirow[t]{2}{*}{2006} & \multicolumn{2}{|c|}{2007} \\
\hline & & & & & Jun. & Sept. \\
\hline \multicolumn{7}{|l|}{ Central government domestic debt: by creditor } \\
\hline \multicolumn{7}{|l|}{ Bank of Papua New Guinea } \\
\hline Net credit to central government & 243 & -26 & -538 & -659 & -540 & $-1,100$ \\
\hline Securities & 256 & 76 & 106 & 143 & 194 & 204 \\
\hline Treasury bills $1 /$ & 180 & 0 & 0 & 0 & 0 & 0 \\
\hline Inscribed stock $2 /$ & 76 & 76 & 106 & 143 & 194 & 204 \\
\hline Temporary advance & 94 & 3 & 2 & 1 & 42 & 5 \\
\hline Less: Deposits & 106 & 105 & 646 & 803 & 776 & 1,310 \\
\hline \multicolumn{7}{|l|}{ Other Depository Corporations } \\
\hline Net credit to central government & 1,010 & 1,320 & 1,652 & 1,625 & 1,367 & 1,086 \\
\hline Securities & 1,248 & 1,593 & 2,013 & 2,241 & 2,092 & 1,802 \\
\hline Treasury bills $1 /$ & 1,248 & 1,157 & 1,118 & 1,012 & 668 & 482 \\
\hline Inscribed stock 2/ & 0 & 436 & 895 & 1,229 & 1,425 & 1,320 \\
\hline Loans & 2 & 1 & 1 & 11 & 1 & 1 \\
\hline Less: Deposits & 240 & 275 & 361 & 627 & 726 & 717 \\
\hline \multicolumn{7}{|l|}{ Nonbanks } \\
\hline Net credit to central government & 1,479 & 1,511 & 1,275 & 684 & 663 & 631 \\
\hline Securities & 1,426 & 1,465 & 1,246 & 654 & 634 & 601 \\
\hline Treasury bills 2/ & 1,328 & 1,079 & 679 & 139 & 128 & 80 \\
\hline Inscribed stock 2 / & 98 & 386 & 567 & 515 & 506 & 522 \\
\hline Loans & 53 & 46 & 30 & 30 & 30 & 30 \\
\hline Central government net domestic debt: total & 2,732 & 2,804 & 2,390 & 1,649 & 1,490 & 617 \\
\hline Total gross domestic debt & 3,079 & 3,184 & 3,397 & 3,080 & 2,992 & 2,643 \\
\hline Securities & 2,930 & 3,134 & 3,364 & 3,038 & 2,920 & 2,607 \\
\hline Total treasury bills & 2,755 & 2,236 & 1,797 & 1,151 & 795 & 562 \\
\hline Total inscribed stock $2 /$ & 175 & 898 & 1,568 & 1,887 & 2,124 & 2,045 \\
\hline Loans & 149 & 49 & 33 & 42 & 73 & 36 \\
\hline Less: Central government deposits & 346 & 380 & 1,008 & 1,430 & 1,503 & 2,026 \\
\hline
\end{tabular}

Sources: Data provided by the Bank of Papua New Guinea; and Department of Treasury.

1/ Discount value.

2/ Face value. 
Table 10: Papua New Guinea: Monetary Survey, 2003-September 2007

(In millions of kina; end of period)

\begin{tabular}{|c|c|c|c|c|c|}
\hline & \multirow[t]{2}{*}{2003} & \multirow[t]{2}{*}{2004} & \multirow[t]{2}{*}{2005} & \multirow[t]{2}{*}{2006} & \multirow{2}{*}{$\frac{2007}{\text { Sept }}$} \\
\hline & & & & & \\
\hline Net foreign assets & 1,621 & 2,165 & 2,929 & 4,648 & 6,297 \\
\hline Bank of Papua New Guinea & 1,322 & 1,869 & 2,367 & 4,319 & 5,546 \\
\hline Foreign assets & 1,743 & 2,072 & 2,368 & 4,326 & 5,552 \\
\hline Less: Foreign liabilities & 421 & 203 & 1 & 6 & 6 \\
\hline Other Depository Coporations & 299 & 296 & 562 & 329 & 751 \\
\hline Net domestic assets & 1,789 & 1,750 & 2,141 & 2,392 & 1,485 \\
\hline Domestic credit & 3,046 & 3,066 & 3,329 & 3,975 & 3,699 \\
\hline Net credit to central government & 1,253 & 1,293 & 1,114 & 966 & -14 \\
\hline Bank of Papua New Guinea & 243 & -26 & -538 & -659 & $-1,100$ \\
\hline Claims on central government & 350 & 79 & 108 & 144 & 209 \\
\hline Less: Central government deposits & 106 & 105 & 646 & 803 & 1,310 \\
\hline Other Depository Corporations & 1,010 & 1,320 & 1,652 & 1,625 & 1,086 \\
\hline Claims on central government & 1,250 & 1,594 & 2,014 & 2,252 & 1,803 \\
\hline Securities & 1,248 & 1,593 & 2,013 & 2,241 & 1,802 \\
\hline Loans & 2 & 1 & 1 & 11 & 1 \\
\hline Less: Central government deposits & 240 & 275 & 361 & 627 & 717 \\
\hline Claims on other sectors & 1,793 & 1,773 & 2,215 & 3,009 & 3,713 \\
\hline Claims on the private sector & 1,707 & 1,724 & 2,133 & 2,947 & 3,654 \\
\hline Claims on official entities & 79 & 48 & 81 & 60 & 59 \\
\hline Claims on nonmonetary financial institutions & 6 & 1 & 1 & 1 & 0 \\
\hline Other items, net & $-1,256$ & $-1,316$ & $-1,188$ & $-1,582$ & $-2,215$ \\
\hline Broad money & 3,410 & 3,915 & 5,069 & 7,041 & 7,782 \\
\hline Narrow money & 1,707 & 2,232 & 3,017 & 3,792 & 4,379 \\
\hline Currency outside banks & 388 & 400 & 445 & 520 & 599 \\
\hline Demand deposits & 1,319 & 1,832 & 2,572 & 3,272 & 3,780 \\
\hline Quasi money & 1,704 & 1,683 & 2,052 & 3,249 & 3,402 \\
\hline \multicolumn{6}{|l|}{ Memorandum items: } \\
\hline Narrow money growth rate $1 /$ & 6.7 & 30.8 & 35.2 & 25.7 & 27.2 \\
\hline Broad money growth rate $1 /$ & -4.4 & 14.8 & 29.5 & 38.9 & 25.2 \\
\hline Private sector credit growth rate $1 /$ & -4.1 & 0.9 & 23.7 & 38.2 & 35.6 \\
\hline Nominal nonmineral GDP/broad money & 3.0 & 2.6 & 2.3 & 1.8 & $\ldots$ \\
\hline
\end{tabular}

Sources: Data provided by the Papua New Guinea authorities; and Fund staff estimates.

1/ Percent change from corresponding period of previous year. 
Table 11: Papua New Guinea: Balance Sheet of the Central Bank, 2003-September 2007

(In millions of kina; end of period)

\begin{tabular}{|c|c|c|c|c|c|}
\hline & \multirow[t]{2}{*}{2003} & \multirow[t]{2}{*}{2004} & \multirow[t]{2}{*}{2005} & \multirow[t]{2}{*}{2006} & \multirow{2}{*}{$\frac{2007}{\text { Sept }}$} \\
\hline & & & & & \\
\hline Net foreign assets & 1,322 & 1,869 & 2,367 & 4,319 & 5,546 \\
\hline Foreign assets & 1,743 & 2,072 & 2,368 & 4,326 & 5,552 \\
\hline Less: Foreign liabilities & 421 & 203 & 1 & 6 & 6 \\
\hline Of which: Non-IMF liabilities & 13 & 1 & 1 & 6 & 6 \\
\hline Net domestic assets & -653 & -998 & $-1,432$ & $-3,181$ & $-4,423$ \\
\hline Domestic credit & 308 & 7 & -502 & -601 & $-1,067$ \\
\hline Net credit to government & 243 & -26 & -538 & -659 & $-1,100$ \\
\hline Securities & 256 & 76 & 106 & 143 & 204 \\
\hline Treasury bills & 180 & 0 & 0 & 0 & 0 \\
\hline Inscribed stock & 76 & 76 & 106 & 143 & 204 \\
\hline Advances & 94 & 3 & 2 & 1 & 5 \\
\hline Less: Central government deposits & 106 & 105 & 646 & 803 & 1,310 \\
\hline Credit to other sectors & 64 & 34 & 36 & 58 & 34 \\
\hline Claims on the private sector & 7 & 9 & 11 & 32 & 10 \\
\hline Claims on deposit money banks & 50 & 24 & 24 & 26 & 24 \\
\hline Claims on nonmonetary financial institutions & 6 & 1 & 1 & 1 & 0 \\
\hline Other items net & -961 & $-1,006$ & -929 & $-2,580$ & $-3,356$ \\
\hline Reserve money & 669 & 871 & 935 & 1,138 & 1,123 \\
\hline Currency in circulation & 512 & 531 & 606 & 693 & 761 \\
\hline Deposits of other depository corporations & 153 & 332 & 322 & 442 & 359 \\
\hline ESA deposits & 66 & 231 & 184 & 246 & 142 \\
\hline CRR deposits & 87 & 101 & 138 & 196 & 217 \\
\hline Other deposits & 4 & 8 & 8 & 3 & 3 \\
\hline \multicolumn{6}{|l|}{ Memorandum items: } \\
\hline Reserve money growth $1 /$ & -0.1 & 30.2 & 7.4 & 21.7 & 16.0 \\
\hline Use of fund credit (millions of U.S. dollars) & 121.5 & 64.3 & 0.0 & 0.0 & 0.0 \\
\hline Gross international reserves (millions of U.S. dollars) & 522.9 & 663.1 & 764.9 & $1,427.5$ & $1,887.7$ \\
\hline Exchange rate (U.S. dollar/kina) & 0.30 & 0.32 & 0.32 & 0.33 & 0.34 \\
\hline
\end{tabular}

Sources: Data provided by Papua New Guinea authorities; and Fund staff estimates.

1/ Percent change from corresponding period of previous year. 
Table 12. Papua New Guinea: Consolidated Balance Sheet of Other Depository Corporations, 2003-September 2007

(In millions of kina; end of period)

\begin{tabular}{|c|c|c|c|c|c|}
\hline & \multirow[t]{2}{*}{2003} & \multirow[t]{2}{*}{2004} & \multirow[t]{2}{*}{2005} & \multirow[t]{2}{*}{2006} & \multirow{2}{*}{2007} \\
\hline & & & & & \\
\hline Net foreign assets & 299 & 296 & 562 & 329 & 751 \\
\hline Foreign assets & 356 & 364 & 658 & 430 & 885 \\
\hline Foreign liabilities & 56 & 69 & 96 & 101 & 134 \\
\hline Reserves & 153 & 332 & 322 & 442 & 359 \\
\hline CRR accounts & 87 & 101 & 138 & 196 & 217 \\
\hline ESA accounts & 66 & 231 & 184 & 246 & 142 \\
\hline Currency & 124 & 131 & 160 & 173 & 162 \\
\hline Domestic credit & 3,136 & 3,788 & 4,655 & 7,038 & 7,774 \\
\hline Net credit to central government & 1,010 & 1,320 & 1,652 & 1,625 & 1,086 \\
\hline Claims on central government & 1,250 & 1,594 & 2,014 & 2,252 & 1,803 \\
\hline Securities & 1,248 & 1,593 & 2,013 & 2,241 & 1,802 \\
\hline Treasury bills & 1,248 & 1,157 & 1,118 & 1,012 & 482 \\
\hline Inscribed stock & 0 & 436 & 895 & 1,229 & 1,320 \\
\hline Inscribed stock of maturity $<3$ years & 0 & 278 & 572 & 785 & 1,159 \\
\hline Inscribed stock of maturity $>3$ years & 0 & 157 & 323 & 444 & 160 \\
\hline Loans & 2 & 1 & 1 & 11 & 1 \\
\hline Less: Central government deposits & 240 & 275 & 361 & 627 & 717 \\
\hline Claims on other sectors & 2,126 & 2,469 & 3,003 & 5,413 & 6,687 \\
\hline Claims on BPNG & 347 & 706 & 800 & 2,437 & 2,984 \\
\hline Claims on the private sector & 1,700 & 1,715 & 2,122 & 2,916 & 3,644 \\
\hline Claims on official entities & 79 & 48 & 81 & 60 & 59 \\
\hline Claims on NFPE's & 73 & 44 & 79 & 57 & 55 \\
\hline Claims on provincial governments & 6 & 4 & 2 & 3 & 5 \\
\hline Claims on nonmonetary financial institutions & 0 & 0 & 0 & 0 & 0 \\
\hline Other items, net & -645 & $-1,019$ & $-1,062$ & $-1,443$ & $-1,845$ \\
\hline Deposits & 3,017 & 3,505 & 4,614 & 6,516 & 7,177 \\
\hline Demand & 1,293 & 1,781 & 2,513 & 3,224 & 3,677 \\
\hline Term & 1,724 & 1,724 & 2,101 & 3,292 & 3,500 \\
\hline Central bank credit & 50 & 24 & 23 & 24 & 24 \\
\hline \multicolumn{6}{|l|}{ Memorandum items: } \\
\hline Deposits subject to reserve requirements & 3,244 & 3,720 & 4,917 & 7,115 & 7,817 \\
\hline Implied cash reserve ratio (percent) & 3 & 3 & 3 & 3 & 3 \\
\hline Kina facility borrowings (-deposits) & 0 & 0 & 0 & 0 & 6 \\
\hline Liquid assets & 1,438 & 1,798 & 2,034 & 2,216 & 1,945 \\
\hline Excess ESA balances & 66 & 231 & 184 & 246 & 142 \\
\hline Total ODC assets & 4,420 & 4,960 & 6,351 & 8,872 & 10,150 \\
\hline Claims on central government/total assets (percent) & 28 & 32 & 32 & 25 & 18 \\
\hline
\end{tabular}

Sources: Data provided by Papua New Guinea authorities; and Fund staff estimates. 
Table 13. Papua New Guinea: Commercial Bank Loans by Sector, 2003-September 2007

\begin{tabular}{|c|c|c|c|c|c|c|c|c|c|c|}
\hline & 2003 & 2004 & 2005 & 2006 & 2007 & 2003 & 2004 & 2005 & 2006 & 2007 \\
\hline & & & & & Sept. & & & & & Sept. \\
\hline \multirow[b]{2}{*}{ Total } & \multicolumn{5}{|c|}{ (In millions of kina; end of period) } & \multicolumn{5}{|c|}{ (In percent of total credit; end of period) } \\
\hline & 1495 & 1421 & 1797 & 2515 & 2968 & 100.0 & 100.0 & 100.0 & 100.0 & 100.0 \\
\hline Business & 1331 & 1223 & 1548 & 2185 & 2540 & 89.0 & 86.1 & 86.2 & 86.9 & 85.6 \\
\hline Agriculture, forestry, and fishing & 51 & 64 & 74 & 141 & 140 & 3.4 & 4.5 & 4.1 & 5.6 & 4.7 \\
\hline Coffee & 3 & 1 & 2 & 6 & 11 & 0.2 & 0.1 & 0.1 & 0.3 & 0.4 \\
\hline Cocoa & 1 & 24 & 10 & 10 & 5 & 0.1 & 1.7 & 0.5 & 0.4 & 0.2 \\
\hline Coconut products & 0 & 1 & 0 & 0 & 0 & 0.0 & 0.0 & 0.0 & 0.0 & 0.0 \\
\hline Palm oil & 0 & 0 & 2 & 2 & 0 & 0.0 & 0.0 & 0.1 & 0.1 & 0.0 \\
\hline Fisheries & 7 & 19 & 22 & 23 & 30 & 0.4 & 1.4 & 1.2 & 0.9 & 1.0 \\
\hline Forestry & 21 & 8 & 18 & 37 & 17 & 1.4 & 0.5 & 1.0 & 1.5 & 0.6 \\
\hline Other $1 /$ & 20 & 12 & 21 & 63 & 77 & 1.3 & 0.8 & 1.1 & 2.5 & 2.6 \\
\hline Manufacturing & 99 & 95 & 114 & 124 & 166 & 6.6 & 6.7 & 6.4 & 4.9 & 5.6 \\
\hline Engineering and metal processing & 6 & 3 & 25 & 28 & 39 & 0.4 & 0.2 & 1.4 & 1.1 & 1.3 \\
\hline Food, drink, and tobacco processing & 71 & 45 & 45 & 53 & 79 & 4.8 & 3.2 & 2.5 & 2.1 & 2.7 \\
\hline Textile, leather, and wood products & 9 & 10 & 5 & 10 & 12 & 0.6 & 0.7 & 0.3 & 0.4 & 0.4 \\
\hline Chemicals, paints, and gases & 1 & 0 & 4 & 12 & 2 & 0.1 & 0.0 & 0.2 & 0.5 & 0.1 \\
\hline Other 2/ & 12 & 36 & 36 & 21 & 34 & 0.8 & 2.5 & 2.0 & 0.8 & 1.1 \\
\hline Transport and communication & 124 & 72 & 123 & 202 & 243 & 8.3 & 5.1 & 6.8 & 8.0 & 8.2 \\
\hline Finance & 13 & 25 & 28 & 60 & 14 & 0.9 & 1.7 & 1.6 & 2.4 & 0.5 \\
\hline Commerce & 373 & 384 & 438 & 479 & 600 & 25.0 & 27.0 & 24.4 & 19.0 & 20.2 \\
\hline Retail trade & 265 & 214 & 280 & 134 & 140 & 17.7 & 15.1 & 15.6 & 5.3 & 4.7 \\
\hline Buyers, processors, and exporters & 75 & 94 & 113 & 42 & 71 & 5.0 & 6.6 & 6.3 & 1.7 & 2.4 \\
\hline Wholesale trade & 33 & 76 & 45 & 303 & 389 & 2.2 & 5.3 & 2.5 & 12.1 & 13.1 \\
\hline Building and construction & 66 & 66 & 106 & 125 & 150 & 4.4 & 4.7 & 5.9 & 5.0 & 5.1 \\
\hline Mining and quarrying & 20 & 6 & 14 & 144 & 55 & 1.3 & 0.4 & 0.8 & 5.7 & 1.9 \\
\hline Metals and other mining & 6 & 6 & 14 & 141 & 50 & 0.4 & 0.4 & 0.8 & 5.6 & 1.7 \\
\hline Petroleum and natural gas & 14 & 0 & 0 & 4 & 6 & 0.9 & 0.0 & 0.0 & 0.1 & 0.2 \\
\hline Other business $3 /$ & 587 & 511 & 652 & 911 & 1172 & 39.2 & 36.0 & 36.3 & 36.2 & 39.5 \\
\hline Government & 8 & 5 & 3 & 15 & 6 & 0.6 & 0.3 & 0.2 & 0.6 & 0.2 \\
\hline Central government 4/ & 2 & 1 & 1 & 11 & 1 & 0.1 & 0.1 & 0.1 & 0.5 & 0.0 \\
\hline Provincial government & 3 & 2 & 1 & 3 & 4 & 0.2 & 0.1 & 0.1 & 0.1 & 0.1 \\
\hline Local government & 3 & 2 & 1 & 1 & 1 & 0.2 & 0.1 & 0.1 & 0.0 & 0.0 \\
\hline Persons & 156 & 193 & 246 & 315 & 422 & 10.4 & 13.6 & 13.7 & 12.5 & 14.2 \\
\hline Advances for housing & 103 & 121 & 145 & 176 & 202 & 6.9 & 8.5 & 8.1 & 7.0 & 6.8 \\
\hline Other personal loans & 52 & 73 & 101 & 140 & 220 & 3.5 & 5.1 & 5.6 & 5.5 & 7.4 \\
\hline
\end{tabular}

Source: Bank of Papua New Guinea, Quarterly Economic Bulletin.

$1 /$ Includes rubber, tea, and cattle.

$2 /$ Includes printing and packaging.

$3 /$ Includes hotels and restaurants, real estate, renting and business services, electricity, and gas and water supply.

4/ Excludes short-term government debt instruments and other deposits. 
Table 14. Papua New Guinea: Reserve Requirements, March 1997-September 2007

(In percent)

\begin{tabular}{lccc}
\hline Period & $\begin{array}{c}\text { Cash reserve } \\
\text { requirement }\end{array}$ & $\begin{array}{c}\text { Minimum liquid } \\
\text { assets ratio }\end{array}$ & $\begin{array}{c}\text { Total } \\
\text { requirement }\end{array}$ \\
\hline March 1997-July 1998 & 0 & 20 & 20 \\
August 1998-November 1998 & 0 & 20 & 20 \\
December 1998-January 12, 1999 & 0 & 0 & 0 \\
January 15, 1999-February 1999 & 10 & 0 & 10 \\
March 1999-May 1999 & 5 & 15 & 15 \\
June 1999-August 1999 1/ & 5 & 20 & 25 \\
September 1999-December 2002 & 5 & 25 & 30 \\
October 2003-September 2007 & 3 & 25 & 28 \\
& & & \\
\hline
\end{tabular}

Source: Bank of Papua New Guinea.

1/ From June 1999, CRR deposits at the central bank were excluded from the definition of liquid assets. 


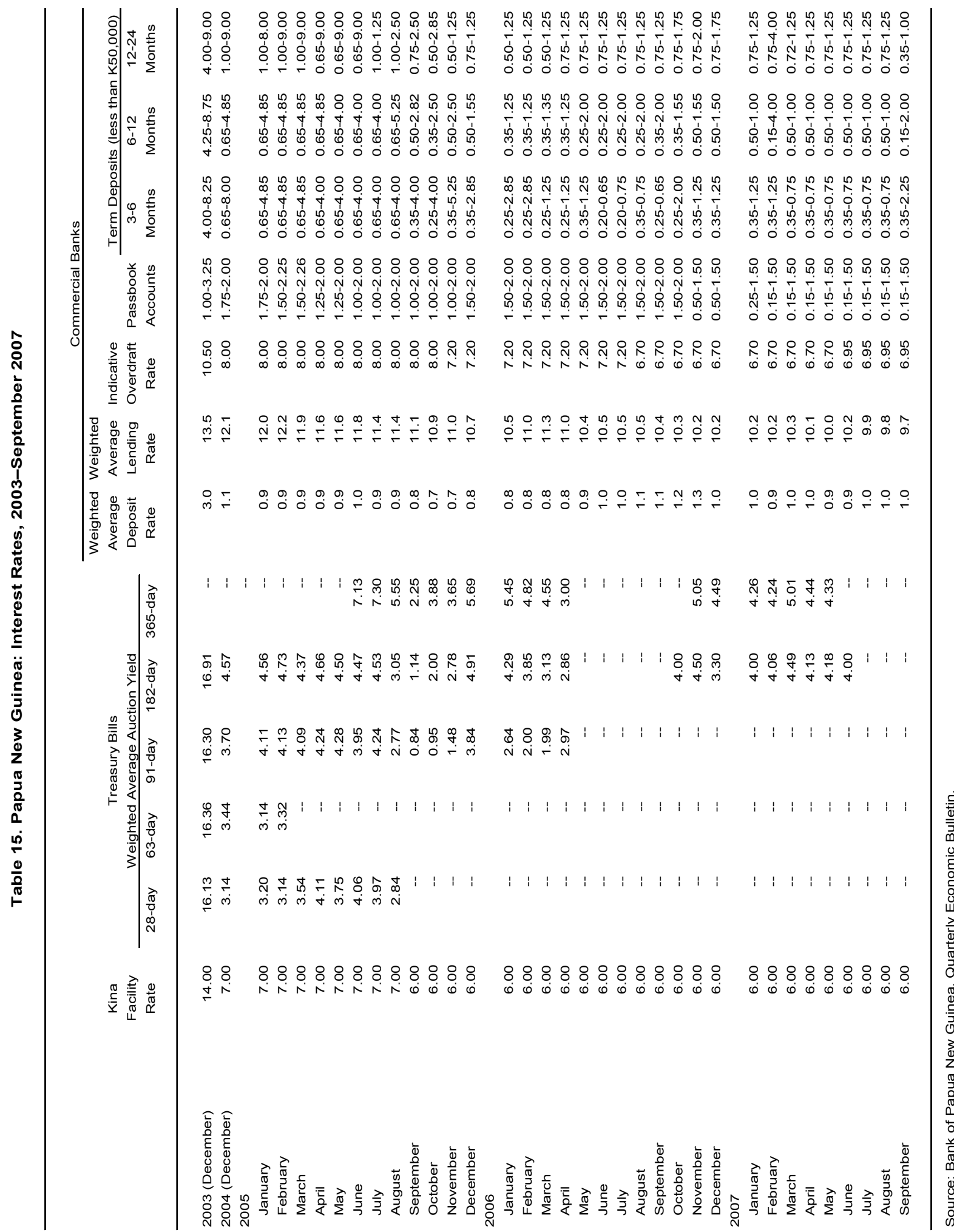


Table 16. Papua New Guinea: Balance of Payments, 2003-06

(In millions of U.S. dollars)

\begin{tabular}{|c|c|c|c|c|}
\hline & 2003 & 2004 & 2005 & 2006 \\
\hline Current account balance & 159 & 88 & 207 & 163 \\
\hline Mineral & 728 & 793 & 1,044 & 1,364 \\
\hline Nonmineral & -569 & -705 & -837 & $-1,201$ \\
\hline Trade balance & 718 & 760 & 816 & 1,400 \\
\hline Exports (f.o.b.) & 2,153 & 2,554 & 3,278 & 4,205 \\
\hline Mineral & 1,635 & 1,863 & 2,467 & 3,391 \\
\hline Nonmineral & 518 & 690 & 811 & 814 \\
\hline Imports (c.i.f.) & $-1,435$ & $-1,794$ & $-2,462$ & $-2,805$ \\
\hline Mineral & -325 & -482 & -693 & -795 \\
\hline Nonmineral & $-1,109$ & $-1,312$ & $-1,769$ & $-2,010$ \\
\hline Services & -388 & -485 & -674 & -882 \\
\hline Income & -407 & -368 & -369 & -632 \\
\hline Current Transfers & 235 & 182 & 434 & 276 \\
\hline Official & 199 & 142 & 393 & 299 \\
\hline Private & 36 & 40 & 41 & -23 \\
\hline Capital and financial account balance & -23 & 35 & 0 & 470 \\
\hline Direct investment & 97 & 26 & 68 & 193 \\
\hline Other investment & -120 & 10 & -68 & 277 \\
\hline Medium- and long-term loan disbursements & -151 & -213 & -175 & -137 \\
\hline Commercial banks & -60 & -1 & -87 & 77 \\
\hline Other & 90 & 224 & 194 & 337 \\
\hline Net errors and omissions & 52 & 82 & -46 & 29 \\
\hline Overall balance & 187 & 206 & 161 & 662 \\
\hline Financing & -187 & -206 & -161 & -662 \\
\hline Reserve assets & -184 & -140 & -102 & -662 \\
\hline Use of IMF credit & -6 & -62 & -59 & 0 \\
\hline Purchases & 0 & 0 & 0 & 0 \\
\hline Repurchases & -6 & -62 & -59 & 0 \\
\hline Other foreign liabilities & 3 & -4 & 0 & 0 \\
\hline \multicolumn{5}{|l|}{ Memorandum items: } \\
\hline Current account (in percent of GDP) & 4.5 & 2.2 & 4.2 & 2.9 \\
\hline Mineral & 20.6 & 20.2 & 21.2 & 24.4 \\
\hline Nonmineral & -16.1 & -17.9 & -17.0 & -21.5 \\
\hline \multicolumn{5}{|l|}{ Gross official reserves (end-year) } \\
\hline In millions of U.S. dollars & 523 & 663 & 765 & 1,427 \\
\hline In months of nonmineral imports & 5.7 & 6.1 & 5.2 & 8.5 \\
\hline In months of imports of goods and nonfactor services & 2.7 & 2.8 & 2.4 & 3.8 \\
\hline Public external debt-service-exports ratio (in percent) & 7.5 & 8.7 & 6.0 & 3.5 \\
\hline Public external debt-GDP ratio (in percent) $1 /$ & 42.9 & 36.8 & 25.8 & 21.2 \\
\hline
\end{tabular}

Sources: Data provided by the Papua New Guinea authorities; and Fund staff estimates.

1/ Public external debt includes central government, central bank external debt, and statutory authorities. 
Table 17. Papua New Guinea: Exports of Major Commodities, 2003-06

\begin{tabular}{|c|c|c|c|c|}
\hline & 2003 & 2004 & 2005 & 2006 \\
\hline \multicolumn{5}{|l|}{ Copper } \\
\hline Value (in million of U.S. dollars) & 393.0 & 478.7 & 805.5 & 1413.5 \\
\hline Volume (thousands of tons) & 230.6 & 173.9 & 226.1 & 216.7 \\
\hline Unit value (U.S. dollars per ton) & 1704.2 & 2753.0 & 3562.7 & 6522.9 \\
\hline Unit value (U.S. cents per pound) & 77.3 & 124.9 & 161.6 & 295.9 \\
\hline \multicolumn{5}{|l|}{ Gold } \\
\hline Value (in million of U.S. dollars) & 780.0 & 861.8 & 913.7 & 998.2 \\
\hline Volume (tons) & 68.4 & 67.3 & 70.5 & 56.7 \\
\hline Unit value (U.S. dollars per ounce) & 354.7 & 398.3 & 403.1 & 547.6 \\
\hline \multicolumn{5}{|l|}{ Petroleum } \\
\hline Value (in million of U.S. dollars) & 452.5 & 512.6 & 735.5 & 967.4 \\
\hline Volume (thousands of barrels) & 14983.4 & 12564.7 & 13299.8 & 14521.1 \\
\hline Unit value (U.S. dollars per barrel) & 30.2 & 40.8 & 55.3 & 66.6 \\
\hline \multicolumn{5}{|l|}{ Silver } \\
\hline Value (in million of U.S. dollars) & 9.3 & 10.1 & 12.4 & 12.3 \\
\hline Volume (tons) & 64.2 & 46.7 & 52.1 & 48.0 \\
\hline Unit value (U.S. dollars per ounce) & 4.5 & 6.7 & 7.4 & 8.0 \\
\hline \multicolumn{5}{|l|}{ Logs } \\
\hline Value (in million of U.S. dollars) & 102.6 & 110.3 & 130.5 & 179.9 \\
\hline Volume (thousands of cu. meters) & 2016.0 & 2012.0 & 2270.0 & 2653.0 \\
\hline Unit value (U.S. dollars per cubic meter) & 50.9 & 54.8 & 57.5 & 67.8 \\
\hline \multicolumn{5}{|l|}{ Coffee } \\
\hline Value (in million of U.S. dollars) & 82.8 & 88.0 & 151.8 & 145.0 \\
\hline Volume (thousands of tons) & 68.8 & 63.0 & 72.1 & 52.3 \\
\hline Unit value (U.S. dollars per ton) & 1203.5 & 1396.9 & 2106.1 & 2773.4 \\
\hline Unit value (U.S. cents per pound) & 54.6 & 63.4 & 95.5 & 125.8 \\
\hline \multicolumn{5}{|l|}{ Cocoa } \\
\hline Value (in million of U.S. dollars) & 71.5 & 67.6 & 64.1 & 65.7 \\
\hline Volume (thousands of tons) & 40.3 & 41.5 & 44.2 & 44.0 \\
\hline Unit value (U.S. dollars per ton) & 1774.2 & 1629.0 & 1449.3 & 1492.4 \\
\hline \multicolumn{5}{|l|}{ Palm oil } \\
\hline Value (in million of U.S. dollars) & 116.9 & 136.0 & 126.1 & 149.9 \\
\hline Volume (thousands of tons) & 326.9 & 339.0 & 345.6 & 362.3 \\
\hline Unit value (U.S. dollars per ton) & 357.6 & 401.3 & 364.9 & 413.7 \\
\hline \multicolumn{5}{|l|}{ Copra } \\
\hline Value (in million of U.S. dollars) & 1.8 & 5.3 & 5.6 & 3.0 \\
\hline Volume (thousands of tons) & 8.4 & 19.2 & 22.3 & 12.7 \\
\hline Unit value (U.S. dollars per ton) & 214.3 & 277.8 & 250.1 & 235.8 \\
\hline \multicolumn{5}{|l|}{ Copra Oil } \\
\hline Value (in million of U.S. dollars) & 18.7 & 25.1 & 30.2 & 22.7 \\
\hline Volume (thousands of tons) & 47.7 & 45.1 & 54.4 & 41.5 \\
\hline Unit value (U.S. dollars per ton) & 392.0 & 556.9 & 555.3 & 546.5 \\
\hline \multicolumn{5}{|l|}{ Tea } \\
\hline Value (in million of U.S. dollars) & 5.4 & 7.1 & 6.5 & 7.0 \\
\hline Volume (thousands of tons) & 6.6 & 8.1 & 6.9 & 6.6 \\
\hline Unit value (U.S. dollars per ton) & 818.2 & 876.7 & 943.8 & 1054.2 \\
\hline Unit value (U.S. cents per kilogram) & 81.8 & 87.7 & 94.4 & 105.4 \\
\hline \multicolumn{5}{|l|}{ Rubber } \\
\hline Value (in million of U.S. dollars) & 3.4 & 4.3 & 5.8 & 8.0 \\
\hline Volume (thousands of tons) & 4.2 & 3.8 & 4.8 & 4.4 \\
\hline Unit value (U.S. dollars per ton) & 809.5 & 1126.2 & 1209.0 & 1818.8 \\
\hline Unit value (U.S. cents per pound) & 36.7 & 51.1 & 58.8 & 82.5 \\
\hline \multicolumn{5}{|l|}{ Other } \\
\hline Value (in million of U.S. dollars) & 115.0 & 246.6 & 290.3 & 232.6 \\
\hline Total exports (in million of U.S. dollars) & 2153.0 & 2553.7 & 3278.0 & 4205.2 \\
\hline Minerals and petroleum & 1634.8 & 1863.3 & 2467.1 & 3391.5 \\
\hline Nonmineral & 518.2 & 690.4 & 810.9 & 813.7 \\
\hline
\end{tabular}

Sources: Data provided by the Papua New Guinea authorities; and Fund staff estimates. 
Table 18. Papua New Guinea: Direction of Trade, 2003-06 1/

(In percent of total)

\begin{tabular}{|c|c|c|c|c|}
\hline & 2003 & 2004 & 2005 & 2006 \\
\hline \multicolumn{5}{|l|}{ Exports (f.o.b.) by destination } \\
\hline Australia & 45.7 & 45.6 & 43.2 & 40.7 \\
\hline Japan & 12.8 & 10.8 & 11.3 & 14.3 \\
\hline Philippines & 3.5 & 4.0 & 5.3 & 9.7 \\
\hline Germany & 6.6 & 7.1 & 7.3 & 4.5 \\
\hline South Korea & 5.4 & 6.1 & 7.4 & 4.4 \\
\hline People's Republic of China 2/ & 6.7 & 4.9 & 3.7 & 3.7 \\
\hline Great Britain & 2.5 & 3.5 & 1.9 & 1.4 \\
\hline Indonesia & 1.7 & 1.2 & 0.4 & 1.2 \\
\hline United States & 2.7 & 2.2 & 1.4 & 1.1 \\
\hline Italy & 1.6 & 1.1 & 0.7 & 0.9 \\
\hline Spain & 0.6 & 0.7 & 0.3 & 0.6 \\
\hline Singapore & 2.1 & 2.2 & 1.1 & 0.6 \\
\hline Malaysia & 0.4 & 0.9 & 0.7 & 0.5 \\
\hline Other & 7.7 & 9.8 & 15.5 & 16.4 \\
\hline \multicolumn{5}{|l|}{ Imports (c.i.f.) by origin } \\
\hline Australia & 54.8 & 55.3 & 44.8 & 34.2 \\
\hline United States & 9.6 & 8.1 & 13.8 & 21.0 \\
\hline Singapore & 6.6 & 6.0 & 6.4 & 19.2 \\
\hline Japan & 4.8 & 4.4 & 3.9 & 5.0 \\
\hline New Zealand & 5.2 & 3.3 & 5.0 & 2.8 \\
\hline People's Republic of China 2/ & 4.6 & 3.2 & 2.0 & 2.2 \\
\hline Malaysia & 2.3 & 1.7 & 1.7 & 2.1 \\
\hline Indonesia & 2.0 & 1.5 & 1.5 & 1.2 \\
\hline Hong Kong & 0.9 & 0.8 & 1.2 & 1.1 \\
\hline Great Britain & 1.0 & 0.7 & 0.4 & 0.7 \\
\hline Germany & 0.3 & 0.1 & 0.7 & 0.5 \\
\hline Taiwan P.O.C. & 0.2 & 0.2 & 0.2 & 0.3 \\
\hline Philippines & 0.3 & 0.2 & 0.5 & 0.3 \\
\hline Other & 7.6 & 14.5 & 18.0 & 9.5 \\
\hline
\end{tabular}

Source: Data provided by the Papua New Guinea authorities.

1/ Ranked based on the 2006 data.

2/ Excluding Hong Kong SAR. 
Table 19. Papua New Guinea: Net Services and Transfers, 2002-06

(In millions of U.S. dollars)

\begin{tabular}{|c|c|c|c|c|c|}
\hline & 2002 & 2003 & 2004 & 2005 & 2006 \\
\hline Services balance (net) & -345.4 & -388.1 & -484.9 & -674.1 & -881.5 \\
\hline Freight, insurance (receipts) & 7.3 & 22.4 & 29.8 & 33.5 & 33.8 \\
\hline Travel payments & -32.1 & -51.3 & -51.7 & -75.9 & -33.5 \\
\hline Mineral & -1.4 & -1.6 & -2.8 & -4.7 & -3.5 \\
\hline Nonmineral & -30.7 & -49.7 & -48.9 & -71.2 & -30.0 \\
\hline Other & -271.8 & -279.0 & -398.1 & -480.3 & -528.5 \\
\hline Receipts & 154.7 & 208.0 & 175.3 & 199.7 & 238.5 \\
\hline Mineral & 32.5 & 41.4 & 45.6 & 70.0 & 88.8 \\
\hline Nonmineral & 122.2 & 166.6 & 129.7 & 129.7 & 149.7 \\
\hline Payments & -426.5 & -487.0 & -573.4 & -680.0 & -767.0 \\
\hline Mineral & -228.5 & -276.3 & -344.0 & -420.0 & -462.0 \\
\hline Nonmineral & -198.0 & -210.7 & -229.4 & -260.0 & -305.0 \\
\hline Other misc. services payments & -48.8 & -80.2 & -64.9 & -151.4 & -353.4 \\
\hline Income (net) & -225.9 & -406.7 & -368.2 & -369.3 & -631.8 \\
\hline Interest & -79.2 & -52.9 & -41.9 & -21.5 & -78.4 \\
\hline Receipts & 19.9 & 9.6 & 16.0 & 35.4 & 67.2 \\
\hline Mineral & 9.6 & 1.7 & 10.2 & 13.7 & 35.6 \\
\hline Nonmineral & 5.3 & 0.7 & 0.8 & 0.7 & 1.3 \\
\hline Official & 5.0 & 7.2 & 5.0 & 21.0 & 30.3 \\
\hline Payments & -99.1 & -62.5 & -57.9 & -56.9 & -145.6 \\
\hline Mineral & -33.5 & -12.8 & -10.2 & -10.1 & -98.6 \\
\hline Nonmineral & -15.0 & -0.9 & -4.0 & -7.5 & -8.6 \\
\hline Official & -50.6 & -48.8 & -43.7 & -39.3 & -38.5 \\
\hline Concessional & -45.7 & -44.5 & -40.0 & -37.6 & -37.5 \\
\hline Nonconcessional & -1.3 & -1.4 & -0.8 & -0.7 & -0.6 \\
\hline IMF charges & -3.6 & -2.9 & -2.9 & -1.0 & -0.4 \\
\hline Dividends & -131.3 & -353.8 & -326.3 & -347.8 & -553.4 \\
\hline Receipts & 7.3 & 6.2 & 2.1 & 0.9 & 2.1 \\
\hline Mineral & 4.2 & 5.2 & 0.5 & 0.0 & 0.0 \\
\hline Nonmineral & 3.1 & 1.0 & 1.6 & 0.9 & 2.1 \\
\hline Payments & -138.6 & -360.0 & -328.4 & -348.7 & -555.5 \\
\hline Mineral & -92.6 & -259.1 & -222.7 & -227.8 & -440.0 \\
\hline Nonmineral & -46.0 & -100.9 & -105.7 & -120.9 & -115.5 \\
\hline Other income payments & -15.4 & 0.0 & 0.0 & 0.0 & 0.0 \\
\hline Current Tansfers (net) & 196.6 & 235.1 & 181.7 & 434.3 & 276.4 \\
\hline Official & 174.6 & 199.1 & 141.8 & 393.3 & 299.2 \\
\hline Receipts & 174.6 & 199.1 & 141.8 & 393.3 & 299.2 \\
\hline Australia budgetary support & 0.0 & 5.8 & 0.0 & 0.0 & 0.0 \\
\hline Project \& Commodity aid & 169.2 & 193.3 & 141.8 & 393.3 & 299.2 \\
\hline Other grants & 5.4 & 0.0 & 0.0 & 0.0 & 0.0 \\
\hline Payments & 0.0 & 0.0 & 0.0 & 0.0 & 0.0 \\
\hline Private & 22.0 & 36.0 & 39.9 & 41.0 & -22.9 \\
\hline Receipts & 80.8 & 116.4 & 117.1 & 122.0 & 80.1 \\
\hline Payments & -58.8 & -80.4 & -77.2 & -81.0 & -103.0 \\
\hline
\end{tabular}

Sources: Data provided by the Papua New Guinea authorities; and Fund staff estimates. 
Table 20. Papua New Guinea: External Debt Outstanding, 2002-06

(In millions of U.S. dollars)

\begin{tabular}{|c|c|c|c|c|c|}
\hline & 2002 & 2003 & 2004 & 2005 & 2006 \\
\hline Total external debt & 2304 & 2311 & 2158 & 2048 & 2175 \\
\hline Public external debt $1 /$ & 1570 & 1617 & 1492 & 1273 & 1195 \\
\hline Central government & 1430 & 1473 & 1411 & 1245 & 1194 \\
\hline Multilateral creditors & 841 & 865 & 861 & 818 & 801 \\
\hline Of which: World Bank Group & 363 & 348 & 334 & 326 & 318 \\
\hline Asian Development Bank & 419 & 443 & 452 & 428 & 416 \\
\hline Bilateral creditors & 541 & 553 & 496 & 385 & 352 \\
\hline Of which: Australia & 99 & 87 & 40 & 7 & 3 \\
\hline Japan & 391 & 412 & 406 & 335 & 310 \\
\hline Commercial creditors & 48 & 55 & 54 & 43 & 41 \\
\hline Central bank & 115 & 124 & 64 & 0 & 0 \\
\hline Of which: IMF liabilities & 115 & 120 & 64 & 0 & 0 \\
\hline Commercial statutory authorities & 25 & 20 & 17 & 27 & 0 \\
\hline Private external debt & 733 & 694 & 667 & 776 & 980 \\
\hline Of which: mineral sector & 454 & 415 & 372 & 504 & 703 \\
\hline & \multicolumn{5}{|c|}{ (In percent of GDP) } \\
\hline \multicolumn{6}{|l|}{ Memorandum items } \\
\hline Total external debt & 79.4 & 61.3 & 53.3 & 41.6 & 38.7 \\
\hline Total public external debt $1 /$ & 54.2 & 42.9 & 36.8 & 25.8 & 21.2 \\
\hline Central government external debt & 49.3 & 39.1 & 34.8 & 25.3 & 21.2 \\
\hline Multilateral creditors & 29.0 & 22.9 & 21.3 & 16.6 & 14.2 \\
\hline Bilateral creditors & 18.7 & 14.7 & 12.3 & 7.8 & 6.3 \\
\hline Commercial creditors & 1.7 & 1.5 & 1.3 & 0.9 & 0.7 \\
\hline Central bank & 4.0 & 3.3 & 1.6 & 0.0 & 0.0 \\
\hline Commercial statutory authorities & 0.9 & 0.5 & 0.4 & 0.6 & 0.0 \\
\hline Private external debt & 25.3 & 18.4 & 16.5 & 15.7 & 17.4 \\
\hline
\end{tabular}

Sources: Data provided by the Papua New Guinea authorities.

$1 /$ Including central government, central bank external debt, and statutory authorities. 
Table 21. Papua New Guinea: Public External Debt Service, 2002-06

(In millions of U.S. dollars)

\begin{tabular}{|c|c|c|c|c|c|}
\hline & 2002 & 2003 & 2004 & 2005 & 2006 \\
\hline Total public sector & 142.5 & 182.7 & 241.1 & 212.1 & 158.3 \\
\hline Principal & 92.2 & 133.9 & 197.4 & 172.8 & 119.8 \\
\hline Interest & 50.3 & 48.8 & 43.7 & 39.3 & 38.5 \\
\hline Central government & 139.2 & 174.3 & 176.0 & 151.9 & 157.9 \\
\hline Principal & 92.2 & 128.4 & 135.2 & 113.6 & 119.8 \\
\hline Interest & 47.0 & 45.9 & 40.8 & 38.3 & 38.1 \\
\hline Multilateral creditors & 73.8 & 74.2 & 73.1 & 71.1 & 109.6 \\
\hline Principal & 48.6 & 50.7 & 51.9 & 48.8 & 83.1 \\
\hline Interest & 25.2 & 23.5 & 21.2 & 22.3 & 26.5 \\
\hline World Bank Group & 37.3 & 35.4 & 34.2 & 36.5 & 40.8 \\
\hline Principal & 26.8 & 25.8 & 26.1 & 26.4 & 27.5 \\
\hline Interest & 10.5 & 9.6 & 8.1 & 10.1 & 13.3 \\
\hline Asian Development Bank & 31.1 & 31.8 & 34.0 & 31.5 & 64.9 \\
\hline Principal & 18.2 & 19.2 & 22.3 & 20.7 & 52.6 \\
\hline Interest & 12.9 & 12.6 & 11.7 & 10.8 & 12.3 \\
\hline Other & 5.4 & 7.0 & 4.9 & 3.1 & 3.9 \\
\hline Principal & 3.6 & 5.7 & 3.5 & 1.7 & 3.0 \\
\hline Interest & 1.8 & 1.3 & 1.4 & 1.4 & 0.9 \\
\hline Bilateral creditors & 55.4 & 86.0 & 94.0 & 74.7 & 42.3 \\
\hline Principal & 34.9 & 65.0 & 75.2 & 59.4 & 31.3 \\
\hline Interest & 20.5 & 21.0 & 18.8 & 15.3 & 11.0 \\
\hline Australia & 19.9 & 48.2 & 52.6 & 35.0 & 4.3 \\
\hline Principal & 12.4 & 40.3 & 47.1 & 32.1 & 3.9 \\
\hline Interest & 7.5 & 7.9 & 5.5 & 2.9 & 0.4 \\
\hline China & 0.6 & 0.6 & 0.6 & 0.6 & 0.6 \\
\hline Principal & 0.4 & 0.4 & 0.4 & 0.4 & 0.4 \\
\hline Interest & 0.2 & 0.2 & 0.2 & 0.2 & 0.2 \\
\hline Japan & 29.9 & 31.5 & 31.3 & 32.8 & 31.4 \\
\hline Principal & 18.7 & 20.1 & 19.6 & 21.7 & 21.8 \\
\hline Interest & 11.2 & 11.4 & 11.7 & 11.1 & 9.6 \\
\hline Other & 5.0 & 5.7 & 9.5 & 6.3 & 6.0 \\
\hline Principal & 3.4 & 4.2 & 8.1 & 5.2 & 5.2 \\
\hline Interest & 1.6 & 1.5 & 1.4 & 1.1 & 0.8 \\
\hline Commercial creditors & 10.0 & 14.1 & 8.9 & 6.1 & 6.0 \\
\hline Principal & 8.7 & 12.7 & 8.1 & 5.4 & 5.4 \\
\hline Interest & 1.3 & 1.4 & 0.8 & 0.7 & 0.6 \\
\hline Banks & 7.5 & 6.8 & 4.8 & 0.0 & 0.0 \\
\hline Principal & 7.1 & 6.4 & 4.8 & 0.0 & 0.0 \\
\hline Interest & 0.4 & 0.4 & 0.0 & 0.0 & 0.0 \\
\hline Other & 2.5 & 7.3 & 4.1 & 6.1 & 6.0 \\
\hline Principal & 1.6 & 6.3 & 3.3 & 5.4 & 5.4 \\
\hline Interest & 0.9 & 1.0 & 0.8 & 0.7 & 0.6 \\
\hline Central bank & 3.3 & 8.4 & 65.1 & 60.2 & 0.4 \\
\hline Principal & 0.0 & 5.5 & 62.2 & 59.2 & 0.0 \\
\hline Interest & 3.3 & 2.9 & 2.9 & 1.0 & 0.4 \\
\hline \multicolumn{6}{|l|}{ Memorandum item: } \\
\hline Public debt-service ratio & 7.9 & 7.5 & 8.7 & 6.0 & 3.5 \\
\hline
\end{tabular}

Sources: Data provided by the Papua New Guinea authorities; and Fund staff estimates. 
Table 22. Papua New Guinea: Medium Term Development Strategy-Performance Management Framework, 2000-06 1/

\begin{tabular}{|c|c|c|c|c|c|c|}
\hline \multirow[t]{2}{*}{ Sector } & \multicolumn{2}{|c|}{ Performance 2/ } & \multicolumn{4}{|c|}{ Data Assessment 3/ } \\
\hline & Trend & $\begin{array}{c}\text { Latest } \\
\text { Performance }\end{array}$ & $\begin{array}{l}\text { Well-defined } \\
\text { plan }\end{array}$ & $\begin{array}{l}\text { Established } \\
\text { Performance } \\
\text { Indicators }\end{array}$ & $\begin{array}{c}\text { Regularity of } \\
\text { Data }\end{array}$ & $\begin{array}{c}\text { Reliability of } \\
\text { Data }\end{array}$ \\
\hline Primary and preventive health & -2 & 2 & S & S & S & $\mathrm{N}$ \\
\hline HIVIAIDS prevention & 0 & 0 & S & $\mathrm{N}$ & $\mathrm{S}$ & $\mathrm{N}$ \\
\hline Basic education & 1 & 1 & S & S & $\mathrm{N}$ & $\mathrm{N}$ \\
\hline Development oriented adult education & -3 & 3 & $\mathrm{~N}$ & $\mathrm{~N}$ & $\mathrm{~N}$ & $\mathrm{~N}$ \\
\hline Transport, maintenance, and rehabilitation & 0 & 2 & $\mathrm{~S}$ & $\mathrm{~N}$ & $\mathrm{P}$ & $\mathrm{P}$ \\
\hline Income earning opportunities & 1 & 0 & $\mathrm{P}$ & $\mathrm{N}$ & $S$ & S \\
\hline Law and justice & -2 & 1 & S & S & S & S \\
\hline Gender & -1 & 1 & $\mathrm{~N}$ & $\mathrm{~N}$ & $\mathrm{~N}$ & $\mathrm{~N}$ \\
\hline Environment & 1 & 1 & $\mathrm{~N}$ & $\mathrm{P}$ & $\mathrm{N}$ & $\mathrm{N}$ \\
\hline Microeconomic & 4 & 5 & S & S & $\mathrm{P}$ & $\mathrm{S}$ \\
\hline Governance & -3 & -1 & $\mathrm{~N}$ & $\mathrm{~N}$ & $\mathrm{~N}$ & $\mathrm{~N}$ \\
\hline Public expenditure management & 2 & 3 & $\mathrm{P}$ & $\mathrm{P}$ & $\mathrm{P}$ & $S$ \\
\hline Public sector reform & 1 & -1 & S & S & $\mathrm{N}$ & $\mathrm{N}$ \\
\hline
\end{tabular}

Source: Data provided by the Papua New Guinea authorities.

1/ Or latest data available.

2/ Scored between -5 and 5 with positive score indicates that development is taking place and a negative scores indicates that the sector is in decline.

3/ $S=$ satisfactory; $N=$ need improvement; $P=$ partially effective. 